\title{
Sexuação segundo Jacques Lacan: o Um, o Outro e o Ser
}

\author{
Versão original
}

Dissertação apresentada ao Instituto de Psicologia da Universidade de São Paulo como parte dos requisitos para obtenção do título de Mestre em Psicologia

Área de concentração: Psicologia Clínica

Orientador: Prof. Dr. Ivan Ramos Estêvão

São Paulo 
AUTORIZO A REPRODUÇÃO E DIVULGAÇÃO TOTAL OU PARCIAL DESTE TRABALHO, POR QUALQUER MEIO CONVENCIONAL OU ELETRÔNICO, PARA FINS DE ESTUDO E PESQUISA, DESDE QUE CITADA A FONTE.

Catalogação na publicação Biblioteca Dante Moreira Leite

Instituto de Psicologia da Universidade de São Paulo Dados fornecidos pelo(a) autor(a)

Santos, Luiz Fellipe de Almeida

Sexuação segundo Jacques Lacan: o Um, o Outro e o Ser / Luiz Fellipe de Almeida Santos; orientador Ivan Ramos Estêvão. -- São Paulo, 2021.

$127 \mathrm{f}$.

Dissertação (Mestrado - Programa de Pós-Graduação em Psicologia Clínica) -Instituto de Psicologia, Universidade de São Paulo, 2021.

1. Psicanálise. 2. Jacques Lacan. 3. sexualidade. 4. ontologia. I. Estêvão, Ivan Ramos, orient. II. Título. 
Nome: Luiz Fellipe de Almeida Santos

Título: Sexuação segundo Jacques Lacan: o Um, o Outro e o Ser

Dissertação apresentada ao Instituto de Psicologia da Universidade de São Paulo como parte dos requisitos para obtenção do título de Mestre em Psicologia

Aprovado em:

Banca examinadora

Prof. Dr.:

Instituição:

Assinatura:

Prof. Dr.:

Instituição:

Assinatura:

Prof. Dr.:

Instituição:

Assinatura: 


\section{Agradecimentos}

Aos meus pais, pela dedicação à minha formação, e à minha irmã, pelo companheirismo.

Ao meu orientador, Ivan Ramos Estêvão, por ter acreditado neste trabalho; pela presença constante e questionadora, inteligentemente dosada com a liberdade oferecida para minhas decisões.

A Paulo Rona, pelo privilégio de sua leitura do meu texto e pelo encorajamento, no exame de qualificação e em sua obra, à investigação além da versão lacaniana dos fatos.

A Christian Dunker, pela inspiradora introdução a Lacan no curso de graduação e pelas pontuações e precisões capitais feitas no exame de qualificação.

Aos funcionários do Instituto de Psicologia da USP, pelo suporte sempre gentil, com especial afeto aos professores com quem tive contato mais direto: Helena Bicalho, Ecléa Bosi (in memoriam), Gustavo Massola, Maria Júlia Kovács.

A Fernando Paixão, pelos cursos memoráveis no Instituto de Estudos Brasileiros.

Aos colegas do grupo de orientação, cujas leituras e comentários ao longo destes dois anos foram indispensáveis para que novas perguntas pudessem surgir.

Aos colegas psi que encontrei ao longo de minha formação, pelo laço.

Aos meus amigos queridos, pela marca que deixam na vida.

Ao CNPq, pela bolsa concedida. 
É sempre o mesmo encontro, quando caem as máscaras: não era ele nem ela.

Jacques Lacan, 1971 


\section{Resumo}

Almeida-Santos, L. F. (2021). Sexuação segundo Jacques Lacan: o Um, o Outro e o Ser (Dissertação de Mestrado). Instituto de Psicologia, Universidade de São Paulo, São Paulo.

Este trabalho teve por objetivo compreender o estatuto formal do masculino e do feminino segundo a negatividade ontológica que constitui o sujeito teorizado por Jacques Lacan. Analisaram-se obras do autor entre 1971 e 1973, momento cujas coordenadas epistemológicas configuram o que será nomeado "sexuação" em 1974. Constatou-se que o sexual é o próprio equívoco material da linguagem, onde o pulsional manifesta o paradoxo que define o significante, referido à unidade sem identidade, sustentado na diferença recíproca sendo diferente de si mesmo. "Homem" e "mulher", o "dois" constitui os lados fracassados desta mesma contradição, a possibilidade de oposição que o simbólico institui pela impossibilidade. Discutiu-se como a psicanálise pode sustentar uma dualidade não identitária à luz da disparidade ex-sistencial que exibe o impasse ontológico do ser sexuado.

Palavras-chave: psicanálise; Jacques Lacan; sexualidade; ontologia. 


\section{Abstract}

Almeida-Santos, L. F. (2021). Sexuation according to Jacques Lacan: the One, the Other and the Being. (Dissertação de Mestrado). Instituto de Psicologia, Universidade de São Paulo, São Paulo.

This work aimed to understand the formal status of masculine and feminine according to the ontological negativity that constitutes the subject theorized by Jacques Lacan. We have analyzed the author's works between 1971 and 1973, a moment whose epistemological coordinates configure what will be called "sexuation" in 1974. It was found that the sexual is the very material equivoque of language, where the pulsional manifests the paradox which defines the signifier, referring to the unity without identity, based on the reciprocal difference being different from itself. "Man" and "woman", the "two" constitutes the failed sides of this same contradiction, the possibility of opposition that the symbolic institutes from its impossibility. It was discussed how psychoanalysis can support a non-identity duality in the light of the ex-sistential disparity that exhibits the ontological impasse of the sexual being.

Keywords: psychoanalysis; Jacques Lacan; sexuality; ontology. 


\section{Résumé}

Almeida-Santos, L. F. (2021). Sexuation selon Jacques Lacan: l'Un, l'Autre et l'Être. (Dissertação de Mestrado). Instituto de Psicologia, Universidade de São Paulo, São Paulo.

Ce travail a eu pour but de comprendre le statut formel du masculin et du féminin selon la négativité ontologique qui constitue le sujet théorisé par Jacques Lacan. On a analysé les œuvres de l'auteur entre 1971 et 1973, moment dont les coordonnées épistémologiques configurent ce qui sera nommé « sexuation » en 1974. On a constaté que le sexuel est le propre équivoque matériel du langage, où le pulsionnel manifeste le paradoxe qui définit le signifiant, renvoyé à l'unité sans identité, fondé sur la différence réciproque étant différent de lui-même. "Homme » et « femme », le « deux » constitue les côtés ratés de cette même contradiction, la possibilité d'opposition que le symbolique institue pour l'impossibilité. On a discuté la façon dont la psychanalyse peut soutenir une dualité non-identitaire à la lumière de la disparité ex-sistentielle qui exhibe l'impasse ontologique de l'être sexué.

Mots-clés : psychanalyse ; Jacques Lacan ; sexualité ; ontologie. 


\section{Sumário}

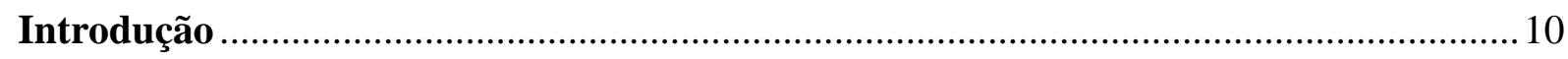

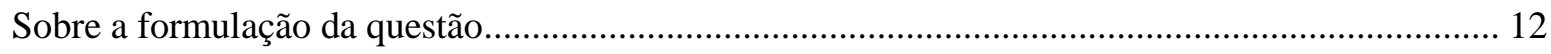

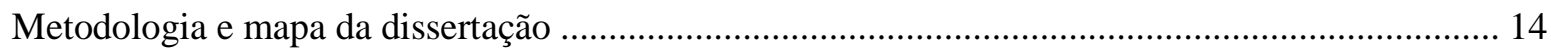

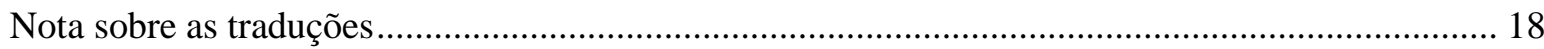

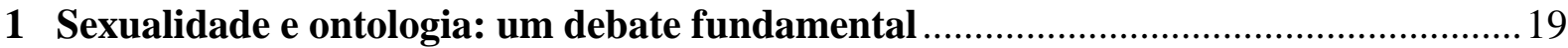

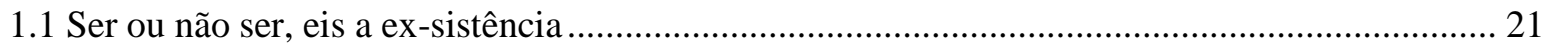

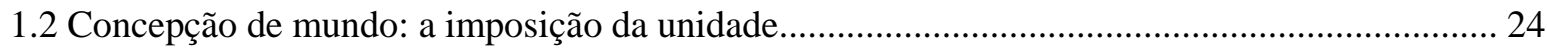

1.3 Função do ser enquanto alma: a ética aristotélica segundo Lacan ........................................... 27

1.4 Inexistência, existência, ex-sistência, insistência ........................................................................ 30

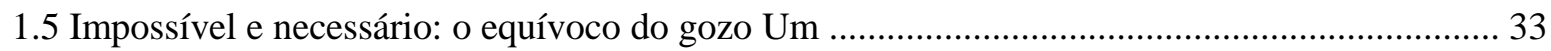

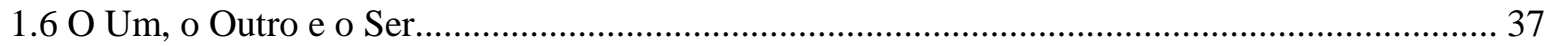

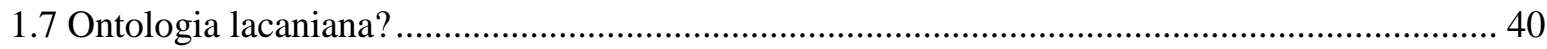

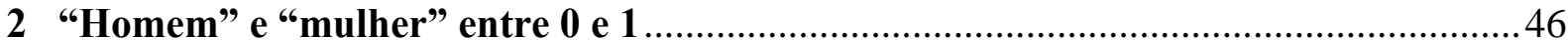

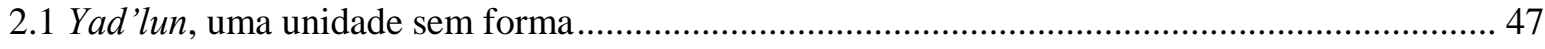

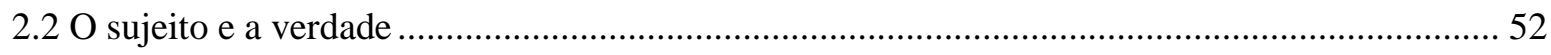

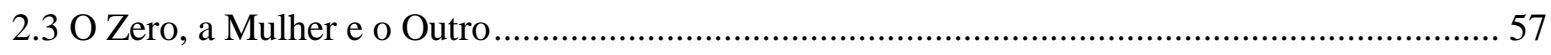

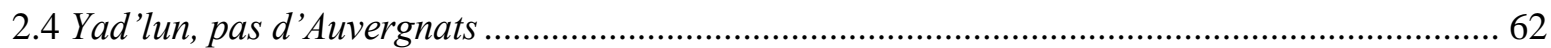

3 Compacidade e ex-sistência: a implicação dos fracassos ............................................. 70

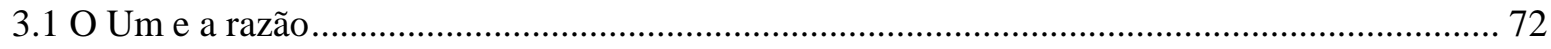

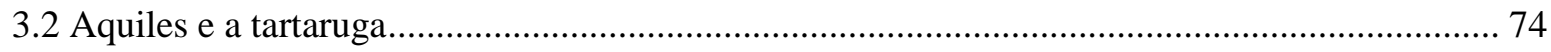

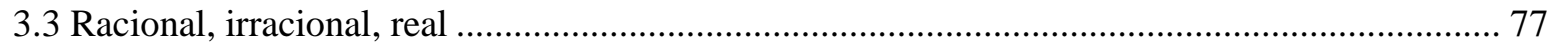

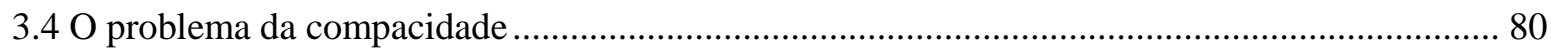

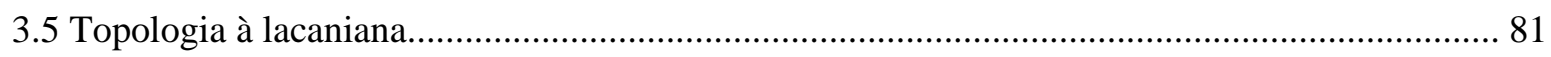

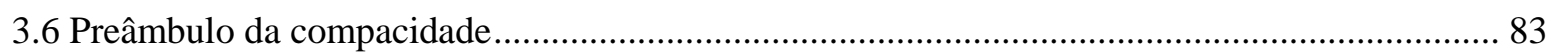

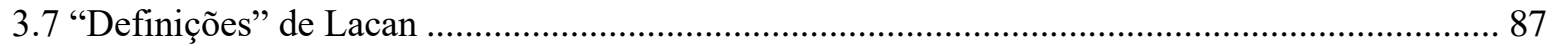

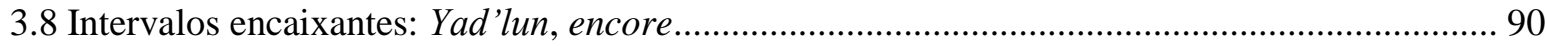

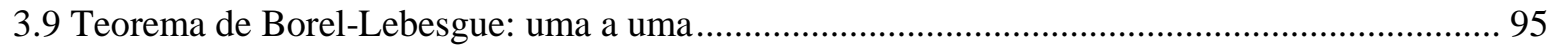

4 A diferença, o sexual: não Um, não Outro, não Ser .............................................. 101

4.1 O Um, o zero: mesmidade da diferença, diferença da mesmidade ......................................... 102

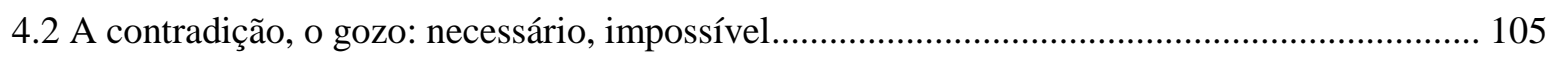

4.3 A negação, a ex-sistência: Um que não, não Um ................................................................ 109

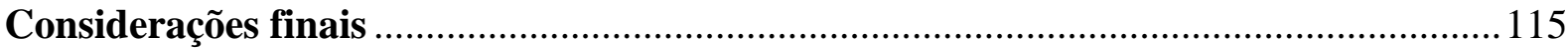

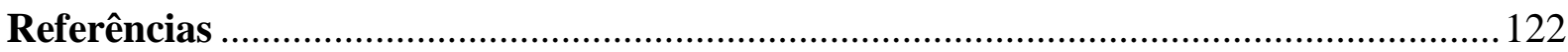




\section{Introdução}

Teorizações pós-lacanianas sobre final de análise não raro resvalam para a binariedade pregnante que emperrou a direção do tratamento freudiana, mas sob outros pressupostos: se em 1937 Freud continuava sem saber o que uma mulher queria, embora soubesse o que todos os neuróticos queriam segundo o eixo fálico/castrado de uma fantasia subordinada, em última instância, à filogenia, nas últimas décadas são abundantes os raciocínios sexuados de final de análise, entre lacanianos, que exercem o tom da prescrição, taxação e bipartição substancial — mesmo que a intenção seja outra (Almeida-Santos \& Ambra, 2021).

O que na superfície textual parece seguir à risca a formalização de Encore (19721973/2010) acaba revelando elucubrações de realidades sexuais que, sob certos ângulos, independeriam das possibilidades do discurso, ou que dependeriam de um discurso que não seria do semblante; como se a anatomia ainda fosse destino. Citemos apenas uma expressão para que a sirene da urgência ressoe: "identidade sexual”, que aparece em Fink (1998, p. 145), Soler (2005, p. 174), Goldenberg (2018, p. 213) e Teixeira (2017, p. 5).

Se Lacan mensurou "homens" e "mulheres" conforme sua relação com o gozo, o sintoma, o semblante, a castração e o inconsciente, seus comentários quantitativos e aproximativos, jocosos e enigmáticos, não pareciam necessariamente distribuir o ser falante segundo tal lógica forçada e incontornável: "seu vínculo [das mulheres] com o nó do desejo é bem mais frouxo"; "a tratá-las de sintomas, não se força a barra, porque definir o sintoma como o fiz, a partir do real, é dizer que as mulheres o exprimem também muito e muito bem, o real"; "a mulher tem uma liberdade muito grande em relação ao semblante"; "a mulher não tem a sofrer nem mais nem menos de castração que o homem"; "as analistas mulheres estão certamente mais à vontade no que se refere ao inconsciente" [itálicos nossos] (Almeida-Santos \& Ambra, 2021; Lacan, 1962-1963/2005, p. 202; 1974/2002; 1971/2019, p. 45; 1974-1975, pp. $30,34)$.

Tais exercícios comparativos, embora por vezes sobrepostos à comédia dos sexos patriarcal, acompanham o movimento de seu ensino, que se manteve tributário da consideração da primazia fálica como fundamento da diferenciação (sexual), sendo justamente o que implica um obstáculo à “bipolaridade sexual” [itálicos nossos] (Lacan, 1971/2019, p. 84). 
"Diferenciação" exprime o processual de "sexuação": um fazer e seus efeitos; escolhas, opções, diz Lacan (1972-1973/2010, 1973-1974/2016). Se os comentadores divergem tanto entre si, é porque no lacanismo parecem concorrer, embutidos em vieses ideológicos, paradigmas de leitura que se sustentam em lógicas distintas, talvez às vezes mesclando a subversão epistemológica com certa inércia de compreensão. Se a lógica é em si mesma dual, sustentada nos binômios afirmativo-negativo, verdadeiro-falso, não é fácil seguir a atualização sofística que Lacan propõe (Cassin, 2017). Retorna-se com frequência a expedientes totalizantes para melhor enxergar o espaço sexuável do ser falante, recaindo em esquemas binários positivos que ressoam divisões socioculturais consolidadas. O clamor essencialista ainda dá espessura ao dizer da diferença na psicanálise tanto quanto o discurso científico busca bipolarizar o sexo por seus atributos, segundo perspectivas e motivações do contexto e da época (Laqueur, 2001).

O peso de traçar identidades em um sistema de pensamento marcado pela constante negativização não deve ser amortecido. Se Lacan se apoiou na paraconsistência para escapar de um universal que se bifurcaria em subclasses simétricas (Le Gaufey, 2015), por que sustentar a identidade para definir a opção de um sujeito que, por definição, resiste a pertencer a qualquer todo? Se ele é dissolvido pelo movimento mesmo de ensaiar sua própria conclusão semântica, se ele está seccionado do saber que diria a verdade de seu Ser, o que haveria de tão identitário no gozar? Como sustentar a noção de identidade sem unidade? Do latim idem ${ }^{1}$, o mesmo, a igualdade no caso do sujeito só poderia ser a representação mesma do paradoxo, pois é uma mesmidade diferente de si mesma, inexistência, núcleo de sua divisão unitária na cadeia significante. Veremos que se trata da ambiguidade que Frege (1884/1992) fundamentou para o zero de sua aritmética, emprestada por Lacan nas exigências do discurso analítico.

Aqui Dunker (2019) detecta o que chama de "naturalização do gozo", perspectiva que compreende a unicidade da substância gozante segundo a problemática atemporalidade do real. Não a natureza, o gozo seria uma substância inacessível, fixa e única sobre a qual agiriam os processos simbólicos tal como a forma moldaria a matéria; ao excesso de gozo corresponderia um déficit significante (p. 100). A falsa oposição entre idealismo e ingenuidade realista designa mais um julgamento existencial do que a problematização epistemológica em jogo. A originalidade da ontologia lacaniana, defende o autor a partir de Safatle (2007) e Badiou (1980), está na articulação temporal do não ser, na qual a disparidade dos gozos exibe a confrontação

\footnotetext{
${ }^{1}$ Etimologicamente, do latim identitatem, substantivo abstrato formado de idem, o mesmo (Littré, 2021).
} 
de temas clássicos da lógica como universalidade e existência. A inexistência não é nada, uma indeterminação trivial, mas uma subversão do próprio conhecer que torna indecidíveis os fundamentos da identidade. Isto é: "se o real se demonstra, se ele não pertence a natureza, se ele não é empiricamente cognoscível, isso não permite defini-lo nem como uma unidade nem como uma multiplicidade" (pp. 103-104).

Que status teria, portanto, a dualidade sexual para Lacan, na medida em que um lado “homem" se oporia a um lado "mulher" (Lacan, 1971-1972/1997) e na medida em que não se trata de "repartir duas séries quaisquer - eu disse quaisquer — de atributos que façam uma série macho, de um lado, e, do outro lado, a série mulher" (Lacan, 1971-1972/2003, p. 130)? O que seria essa oposição não atributiva?

Como a perdição de um ser no gozo, sexuado, pois falante, reparte-se sem a ideia de todo, isto é, sem a ideia de unidade? Como Lacan se apropria do milenar debate ontológico para fazer da divisão de seu sujeito o sexual da diferença, que é a diferença, a noção de diferença que a própria estrutura sincrônica da linguagem institui no rangido de suas peças?

Nesta encruzilhada entre leituras discordantes e densidade epistemológica nas invenções lacanianas dos anos 1970, o que começou como um trabalho de iniciação científica em 2014, sobre "gozo feminino e fim de análise", transformou-se num primeiro projeto de mestrado que questionava a diferença sexual em si mesma, haja vista as incongruências no tema isolado. Em seguida, o retorno a Lacan a partir da disparidade entre seus seguidores, texto apresentado no Exame de Qualificação, chocou-se com a limitação cronológica e epistemológica do projeto: para avaliar o que "não bate" no que é dito hoje é preciso saber o que está em jogo fundamentalmente. Foi aí que uma parte da pesquisa se sombreou para que a luz toda se espalhasse sobre o que exatamente é a sexuação.

\section{Sobre a formulação da questão}

Obviamente a abrangência virtual do tema desta pesquisa implicou a dificuldade no surgimento de suas perguntas. Sexuação, termo inexistente do português mas carregado de sugestões, sobretudo à luz dos aforismos misteriosos de Lacan. "Não há Outro do Outro", “a Mulher não existe", "não há relação/proporção sexual”, "Há Um”: cruzam-se psicanálise, 
linguística, antropologia, filosofia, lógica, matemática, reflexões sobre o saber, sua produção, seu desacordo com a verdade.

Articuladas sob o vocabulário propositalmente polissêmico de Lacan, as disciplinas parecem se entender naturalmente; mas "só se pode compreender o que já se tem na cabeça" (Lacan, 1971, p. 64). Muitas vezes, sem dúvida, a sensível fronteira epistemológica entre elas é esfumaçada para a demonstração do impasse que perpassa o próprio conhecer: é o ponto promissor da apropriação lacaniana, interessada na claudicação do formalismo que sustenta as separações e as uniões concomitantes do que os discursos articulam.

Ora, reside aí a problemática do sexo, cuja inacessibilidade é a mesma de que sofrem os saberes em suas tentativas de fronteirização, convergência e fusão; efeito da matéria que os faz e desfaz, a mesma que aprisiona, reproduz, despedaça, aturde os corpos. Sexual é o nome desta impossibilidade, partida e chegada da descoberta freudiana.

Assim, como formular uma pergunta sobre a sexuação, ciente da monotonia que perpassa esse pluralismo? Sem recair no mantra dos aforismos, na cantilena de seus efeitos entre os comentadores? Sem repetir ingenuamente o que na superfície dos enunciados de Lacan é sedimentação que vem de longe? Sem ficar na aparente segurança dos nomes do impossível, que resolveriam qualquer coisa em psicanálise por atestarem de saída que tudo é inconsistente? Que valeria uma pesquisa se ela já soubesse o que deve à comunidade analítica? Por outro lado, como seguir os fios que enovelam as amarrações lacanianas, um a um, se possível, sem perder a especificidade subversiva que ele defende, o olhar para o que rompe as estruturas? Como seguir a metonímia do desfiamento sem perder o fio da meada?

Isto é: como lidar com a singularidade da epistemologia que Lacan criou, numa pesquisa universitária? Não é uma questão sobre qual afluente epistêmico privilegiar ou como extrair o enodamento mais justo entre as referências, como puro exercício intelectual. Interrogamos o "homem" e a "mulher" de Lacan prismatizados pelas demonstrações de impossibilidade que os saberes produzem, à luz do sexual como falha que define a linguagem, enunciação da letra freudiana.

Como aí figuram o masculino e o feminino? Como estão articulados às metades do sujeito, como Lacan (1973/2003) diz em L'étourdit? O que une e separa o ser sexuado na contradição, implicações negativas do significante, cujo fundamento é o puro exercício da diferença? Como o ser enquanto secção (de predicado), paradoxo (pare-ser) e gozo (falante, sexuado, significância), que Lacan (1972-1973/2010) chama de ex-sistência no 15 de maio de 
1973, se distingue entre "homem" e "mulher"? O que há nesta ligação por impossibilidade que impede um rapport? O que constitui a implicação sexual, se não há proporção? O que faz a continuidade desconexa, nexo desunido, entre o que se chamam sexos? Como eles se afrontam ${ }^{2}$ ex-sistencialmente? Qual o estatuto dessa dualidade se Lacan revira a matemática moderna para provar que o Dois é inacessível? Como a psicanálise sustentaria uma oposição não identitária?

O Um, o Outro e o Ser, subtítulo deste trabalho, parecem orbitar nas reticências que essas perguntas traçam. São os termos-chave de nosso recorte bibliográfico, articulados mais conclusivamente no seminário Encore, entre 1972 e 1973.

A complexidade do que é aqui questionado deixa de lado a discussão sobre a sobreposição dos papéis sexuais tradicionais no formalismo lacaniano. Isto é, nosso olhar voltase para a compreensão epistemológica que preside a sexuação, e não para as implicações sociopolíticas de sua emergência e de sua relevância na atualidade.

Não se advoga com essa observação que a formalização deva se sustentar isolada como serventia puramente lógica ou fruição meramente cognitiva para visualizar como a objetividade da linguagem cria a possibilidade das expressões do sexual. Ao contrário, o que se articula nas letras, nas fórmulas, nas sinuosidades formais, como no discurso, está evidentemente assumido nos efeitos da fala sobre os corpos, articulados no contexto cultural específico em que vivem. Isto é, uma pesquisa sobre psicanálise está necessariamente implicada na experiência que esse discurso produz; mas cada investigação está incontornavelmente comprometida com a coesão de seu recorte metodológico, que faz parte de uma comunidade científica, com suas nuances e oportunidades epistemológicas.

\section{Metodologia e mapa da dissertação}

Este trabalho bibliográfico deteve-se, conforme a seleção de seu projeto, nos seminários de Lacan que mais diretamente discutem a problemática da sexuação. Entre 1971 e 1973: De um discurso que não seria do semblante, O saber do psicanalista, ...ou pior e Encore. O texto

\footnotetext{
${ }^{2}$ Expressão de Lacan no 3 de março de 1972.
} 
L'étourdit, publicado em 1973 na edição de número 4 da revista Scilicet e reeditado nos Outros escritos, também compôs nosso corpus, por condensar as articulações teóricas do período.

Nossa leitura sistematizou-se pela questão principal da pesquisa: o que é o masculino e o feminino segundo a negatividade ontológica do sujeito lacaniano? Seguimos o material do recorte no esforço de compreender essa construção, e buscamos autores referidos por Lacan para que nosso esclarecimento se ampliasse. Comentadores que trabalharam aspectos do assunto também foram selecionados e discutidos no texto da dissertação.

Boa parte de nosso percurso consistiu na lida com naturezas epistemológicas distantes do cotidiano do psicanalista, notadamente a matemática. Nosso recorte permitiu certo aprofundamento que julgamos interessante para o entendimento da implicação formal entre os saberes que interessaram a Lacan. Pensamos que no ponto em que eles denunciam seus paradoxos convergem as respostas possíveis a nossa pergunta: a transdisciplinaridade exibe a fratura comum do "não há rapport sexual".

Questões secundárias a nosso objetivo foram apontadas conforme a coerência metodológica da pesquisa e a pertinência relativa de seu detalhamento. Discutimos brevemente com comentadores sobre o estatuto e a relevância de uma ontologia lacaniana, pois o debate com a filosofia está no coração dos seminários estudados. Também trouxemos questionamentos sobre a qualidade da topologia manipulada por Lacan, considerada a importância que ela teve para parte de nosso trajeto. Não obstante, indicamos nas considerações finais possíveis consequências ou implicações imediatas do que articulamos ao longo da dissertação.

A questão de nosso trabalho é curta mas se ramifica muito frutiferamente. Tentamos manter a coesão nuclear de suas respostas para que nossos objetivos e hipóteses se sustentem. São eles: exprimir como o ontológico é subvertido na própria construção lacaniana da diferença entre os sexos, fundando um novo expediente epistemológico para a compreensão das ferramentas aparentemente naturais do pensamento, como a identidade, a unidade, a universalidade, a particularidade, a diferença. Os efeitos internos que a estrutura da linguagem exibe como modos fracassados de cumprir o que ela produz como imposição na significância — a aparência de ser - se separam como desproporção do sexual, das possibilidades do sexual em suas contradições em torno do verdadeiro. Possibilidades de fiasco, única condição do inconsciente, diz Lacan (1971-1972/2003) em ...ou pior.

São propósitos da dissertação que se formularam no decorrer da pesquisa, constituindo a última versão de seu projeto. Eles desembocaram no breve mapa que expomos a seguir. 
No primeiro capítulo discutimos como Lacan pretende perturbar a inércia cognitiva em torno do Ser, escrito em maiúscula para designar sua pretendida essencialização pela linguagem. O debate é com temas clássicos da filosofia.

A crítica lacaniana é frequentemente unificante, parecendo ecoar o eleatismo e o aristotelismo em tudo o que se produziu na modernidade. A acentuação da ligação verbal, base do princípio de identidade que fundou a metafísica antiga, é alvo privilegiado. O afastamento da contradição, da ambiguidade e do sensorial permitiu às cosmologias a concepção do mundo numa taxonomia a que o pensamento racional teria acesso. Sustentava-a a fantasia de que haveria proporcionalidade e concordância entre a particularidade dos seres, estruturas ônticas cujo saber corporal lhes era propriedade. Ativo e passivo, matéria e forma, pensamento e pensado, milagres do corpo: o par sexual organizava o conhecimento que se pretendia universal.

Facilmente o dois, o três, o quatro, o múltiplo eram concebidos como a tradução perfeita do que o bom exercício da razão podia captar no que era visto e abstraído. Até o ultraje à enumerabilidade abalar para sempre o que o "homem" acreditava ser o seu mundo: declararamno irracional; sem medida, sem unidade, sem todo. Algo indeterminava o que a palavra se esforçava a espelhar.

Platão reconheceu a existência desse não ser, distinção cara ao projeto de Lacan (19721973/2010) em "exorcizar" a identidade segundo o discurso analítico, pois "nada obriga, de modo algum, a isolar esse verbo 'ser'” (p. 98). Justamente o ser é o gozo, repetitivo por não concluir jamais a imagem narcísica que suporta as sintetizações da realidade aparelhada pela unidade sozinha, sem Outro referencial a não ser a contradição que a habita e a obriga a reafirmar sua potência de totalização, unindo e negando, "unegando" [unier]: Yad'lun (Lacan, 1971-1972, p. 78).

O ponto em que fracassa o rapport ambicionado pelos gregos, imaginado conforme a pré-discursividade que transmitira bondosamente seu saber atomístico e teleológico: "Vamos, fale, Unzinho querido, tudo isso não passa de tagarelice”, dizia Parmênides (Lacan, 1971-1972, p. 52).

Discorremos sobre o arsenal epistemológico do Um lacaniano no segundo capítulo. Frege e Cantor são as referências principais: o paradoxo do zero do primeiro, unidade do autodiferente, do inexistente, do indeterminado, e os transfinitos do segundo, segundo uma manipulação peculiar, são articulados com o Parmênides de Platão para demonstrar a inacessibilidade do Dois; isto é, o funcionamento da linguagem entre a presença e a ausência 
de suas peças indefiníveis, articuladas entre si na mesma contradição de ser uma unidade sem forma.

Esse amorfismo que ao mesmo tempo sustenta e corrompe o Um é trabalhado em seguida pela teoria topológica dos conjuntos compactos, referência que Lacan (19721973/2010) faz ligeiramente no início de Encore. O fermento ali salpicado fez a massa do que vínhamos trabalhando crescer até exigir um capítulo próprio, haja vista as seguintes observações-guia que o estruturou: o sujeito distingue-se do significante que o constrange na significação como um número real em uma série racionalmente convergente; um número é limitado na medida de sua infinitude (Lacan, 1971-1972, 1972-1973/2010). Articulam-se aqui, nessa topologização da disparidade dos gozos, o que Lacan (1973/2003, 1972-1973/2010) chama de metades do sujeito em L'étourdit e o que ele observa como reciprocidade total entre o sujeito e o objeto $a$ no final de Encore. Racional e irracional, Um e não Um, efeito de significado e efeito de escrito, existência e inexistência: o debate ontológico parece encontrar na matemática reincidências precisas do fracasso que o simbólico produz por funcionar, chamado de real.

O tratamento relativamente aprofundado da compacidade nos pareceu trazer novos ângulos para explicitar a impossibilidade compartilhada mas seccionada entre o sujeito e seu ensaio de objetivação, como atesta o comentário que Lacan (1972-1973/2010) faz logo em seguida ao assunto: "O que isso quer dizer? . . . o aparecimento de algo onde o sujeito se manifesta em sua hiância, naquilo que causa seu desejo" (p. 24). Impasse que se apresentará ao longo do seminário como paradoxo do gozo, duplicidade sem o Dois.

No quarto capítulo extraímos as consequências do que manejamos previamente para responder nossas questões. Trata-se de um exercício de síntese dos principais agentes epistemológicos dos seminários trabalhados, conforme a singularidade da leitura que fizemos, que desembocará nas considerações finais.

A referência do que rompe os discursos como a sexualização mesma da linguagem nos resume o saldo em que a sexuação se mostra na interrogação lacaniana da estrutura. O que fazer do "homem" e da "mulher" que emitem as consequências da negação do ser do gozo talvez seja uma reflexão clínica que este trabalho possibilite com algum rigor. 


\section{Nota sobre as traduções}

Se ler não obriga a compreender, o trabalho rente ao texto de um autor com a consciência bruta deste fato não poderia se dar por satisfeito com suas traduções, mesmo as mais cuidadosas. As citações de Lacan dividem-se entre: a transcrição integral de seus seminários, disponível no sítio staferla.free.fr, não raro confrontada com os áudios disponíveis na página do psicanalista Patrick Valas (valas.fr), haja vista algumas ambiguidades textuais; as traduções que os membros de algumas instituições brasileiras realizam, como o Centro de Estudos Freudianos do Recife, a Escola Letra Freudiana e o Espaço Moebius; e algumas traduções baseadas no texto estabelecido por Jacques-Alain Miller, editadas pela Jorge Zahar a partir da coleção das Éditions Seuil. Os escritos citados também estão mesclados, notadamente L'étourdit, cujo vocabulário é o mais poético. Foi dada preferência à tradução que julgamos mais próxima da versão original. Todos os trabalhos, não apenas lacanianos, cuja referência é estrangeira foram por nós traduzidos. 


\section{Sexualidade e ontologia: um debate fundamental}

A fala é ação que inaugura a dimensão da verdade e funda fatos naquilo que é dito (Lacan, 1971). Não as coisas, mas efeitos de discurso. Desde que o exercício falante se coloca a conhecer o mundo, a questão mais fundamental é a existência: o que é aquilo que se apresenta a mim? O que define o que percebo, seus contornos, sua profundidade, seu destaque em relação ao resto? O que existe e exige a pergunta de sua natureza? Como se organiza, que relação tem com o que vejo e o que penso? O que distingue sua unidade existencial e como ela se apresenta como verdade? $\mathrm{O}$ que posso saber?

É no corpo que a investigação se funda e reflete o vivido. Um Eu corporal (Freud, 1923/2011) suportado por uma gramática, aprisionado num sentido imaginado, efeito invisível do que nele se inscreve, estabelece lugares e parcializa sua experiência apesar do sentimento conceitual que engloba a fantasia que o define. O "eu" e o "outro" é portanto fundamentalmente um dilema de significação, porquanto o discurso supõe sujeitos ao que se passa de um significante a outro, o que constitui a própria produção de saber.

Assim, o que esse outro significante sabe a partir do que o primeiro comandou? Da Mestria que introduz a enigmatização do conhecer, o que o Outro sabe dela? Segundo Lacan (1972-1973/2010), este é o eixo de seu seminário Encore.

Por quê? Sendo o seminário que segue o acabamento que L'étourdit (1973) dá a sua escrita da proporcionalidade significante impossível, é onde o debate ontológico é mais vívido e categórico. Note-se que ainda não usamos a palavra "sexual”, subentendida em cada intervalo entre os caracteres que aqui se articulam. Se o inconsciente é estruturado como uma linguagem, sendo esta sua condição de ex-sistência, é sua fratura ontológica material que se apresenta como sexual. Se a sexualidade é o fundamento do inconsciente, se o sentido sexual é onde desembocamos, é porque "sexual" designa o próprio limite em que o sentido fracassa: o gozo é limite à verdade porquanto é semblante (Lacan, 1972-1973/2010).

Freud descobriu a sexualidade humana como um problema, um enigma, a própria falta de sentido; não a última instância da capacidade de significação mas a própria impossibilidade de significar. É o resumo dos Três ensaios sobre a teoria da sexualidade (1905/2016). O desvio constitutivo da pulsão - fragmentada, sem objeto adequado, sem objetivo a não ser 
descarregamento de tensão - é o próprio terreno do sexual; uma outra satisfação, sempre dividida, que relança seu objeto sempre alhures; sempre outro: objeto pequeno $a$, semblante de ser cuja essência é o malogro (Lacan, 1972-1973/2010).

O sexual é o pulsional em si mesmo, originalmente desviante; perdição e despedaçamento, em vez de copulação. Não um domínio separado ou pré-estabelecido da experiência humana, pertencente a uma suposta totalidade, descoberto posteriormente por Freud, enfatizado como desembocadura última de sua argumentação. A sexualidade é o próprio impasse do dizer, a insistência da desproporção que subjaz às produções humanas. Como Zupančič (2008) coloca em estilo lacaniano: “o Sexual não existe” [tradução nossa] (p. 11).

O corpo que suporta a falácia da proporção e da relação investe tudo o que funda e funde em fatos de dizer com a falta que mobiliza a própria fundamentação de si mesmo; corpo não enquanto um ser fora do significante, mas a própria demonstração de seus absurdos. O que separa as metades de um encontro sexual é o núcleo da ruptura ontológica do ser falante, que se experimenta como castração. Sua inacessibilidade ao Outro pelo gozo é a própria impossibilidade de objetivação positiva do sujeito, preso ao discurso pelo que o determina pelo desejo, sua irrealização ontológica que se apresenta como diferença entre os sexos: sua própria divisão é a diferença.

Por isso Lacan (1971-1972/2003) martela por todos os cantos que o avanço que empreende gira em torno da existência, eixo de seu seminário ...ou pior. Existir não é ser: homem, mulher, queer, transexual, intersexo, eles não fazem mais do que existir, como significantes. O sentido lógico da existência — "frágil”, “fútil”, “inessencial” (Lacan, 19711972/2003, p. 43) —, mera vacuidade como um argumento numa função, distingue-se da precariedade do sentido semântico em que fingimos nossa verdade, imprime-se como impasse sexual pois não há metalinguagem. Não há Outro dizer que certifique o conhecimento da unidade corporal imaginada, a carne que damos ao significante que nos representa. A existência é a resposta do real enquanto elucubração atestada como para-doxo. É onde Lacan (19721973/2010) assina seu pare-ser. 


\subsection{Ser ou não ser, eis a ex-sistência}

O discurso, enquanto modo de funcionamento da linguagem e laço social, implica lugares, efeitos de escrita condicionados pela impossibilidade maior revelada pelo discurso analítico: não há relação sexual (Lacan, 1972-1973/2010). O que se escreve é gozo, rastro que a linguagem deixa pela erosão do significado, define Lacan (1971/2019) em Lituraterra. Escrevem-se marcas vividas como perdas, a relação do significante com o gozo que define a função fálica, função da falta de escrever uma relação, fusão de dois que formaria uma unidade nova e própria: Фx também é chamada "para não escrever", "ilegível” quanto ao estabelecimento de um rapport, pois repete tentativas de unidade para as quais o Outro é o próprio índice da busca (Lacan, 1971, p. 67).

Que diferença Lacan quer acentuar em relação ao discurso filosófico, colocado genericamente como a serviço do discurso do mestre? Sua referência privilegiada é a filosofia antiga, criticada por tamponar a abertura entre o nível do corpo, do gozo, do semblante e do discurso (Lacan, 1971-1972/2003), cuja presunção é a "consideração do sujeito como ser", o que faz da ontologia uma "vergonha" [honte-logie] (p. 78).

Só o Um existe, resume ...ou pior: o embaraço da unitarização naturalista do indivíduo, terreno tipicamente aristotélico, se dá pela constatação, através dos "nós do simbólico", da impossibilidade de demarcar essa unidade (Lacan, 1972-1973/2003, p. 543). O Um demonstra que o real é matemático, tal como a realidade do número, afirmando-se pela interrogação lógica da linguagem, e não pela intuição da contagem. Como contaríamos $\pi$ ? Assinala-se com uma letra o que inexiste atrás dela, como impossibilidade efetiva da suposição de uma unidade, o que propriamente atesta o real: a função do objeto $a$ é o "deslocamento . . . algo que resiste, quero dizer, do qual não se pode dizer nada" [tradução nossa] (Lacan, 1971-1972, p. 71).

Enquanto a irresolução da existência, impasse metafísico por excelência, tem como outra face a impossibilidade da ontologia dizer o que é o ser, sua objetivação última, o exercício predicativo da consistência do mundo só pode voltar-se à predicação de si mesmo. Modos de consistir que não encontram existências decidíveis: sem que se saiba o que realmente existe, por si mesmo, não se sabe a ordenação dos seres que são, que consistem nesse ser em si, que por sua vez "inconsiste". 
Conforme a oportuna precisão de Morente (1980), sintetizando a impossibilidade fundamental da ontologia, consistir, con-sistere (sustentar-se em, existir junto a), é ser em outro, ser falsamente, consistir nisto ou naquilo, em outra coisa, ser definível na predicação; existir é ser em si, ser autenticamente, não consistir em nada mais, indizível, não ser conceito, ser justamente uma "íntima e fatal experiência própria" [itálico nosso] (Morente, 1980, p. 63). Assim, se a metafísica classicamente se ocupa do problema da verdadeira existência, a ontologia não pode definir aquilo de que se ocupa, mas tão somente assinalar seu lugar. " $O$ que é o ser?" permanece sem resposta, enquanto sua demarcação conceitual se desdobra nas possibilidades de definir a consistência e decidir o lugar da existência através das tortuosas vias que a elucubração do assunto pode assumir. Não obstante, Morente (1980) sublinha que a metafísica e a ontologia não se confundem, não são sinônimos, mas seus problemas convergem no ponto em que a questão sobre a verdade da existência se entrelaça com a questão da unidade, isto é, a dificuldade em definir a objetividade, a natureza dos objetos enquanto tais.

De todo modo, preserva-se basicamente na filosofia antiga a ideia do ser como unidade existencial, aquilo que "há", que "é", e o ser como essência, aquilo que se conceitua, que se descobre pelo trabalho do pensamento; iminentemente uma "individualidade de presença" que carrega uma "idealidade" (Morente, 1980, p. 288, 293). Isto é, na multiplicidade de significações que a palavra "ser" pode assumir preserva-se uma unidade não contraditória, indivisível; o trabalho de unitarização dos objetos resvala para a totalização, mesmo que projetada, de sua verdade.

Podemos pensar a dificuldade da questão do ser como a própria equivocidade do verbo "ser", a tentativa mesma de dizer uma presença, saber o que "há": material ou abstrato, cognoscível ou não, resta acerca da ligação do verbo, a nível da linguagem, a questão da identidade. Lacan (1972-1973/2010) reconhece que o discurso filosófico instaurou "alguns pontos de referência" dificilmente elimináveis em todo o uso do significante: "A ontologia é especialmente aquilo que, por um determinado uso da linguagem, enfatizou, produziu, de um modo acentuado, produziu, na linguagem, o uso do verbo copulativo, de um modo tal que ele foi, em suma, isolado como significante" (p. 97).

Ressalte-se a constante interrogação de Lacan (1972-1973/2010) da ontologia, seu debate com a filosofia, a matemática e a lógica, não apenas no nível epistemológico, a comparação dos saberes, mas enquanto questionamento mesmo da função da linguagem. Justamente pela abordagem da psicanálise sobre o que pode sair do significante se extrai a subversão de sua ontologia, se lhe atribuirmos uma, seu avesso fundamental à primazia do 
conceito e a consequente unificação e totalização semântica que daí resulta, comandada pela ligação do verbo "ser", o mesmo verbo de onde parte o discurso corrente que supõe o rapport sexual (Lacan, 1971-1972). Se a linguagem funciona pelo velamento colorido dos seres que celebra, propõe-se aqui um desvelamento da monotonia de seu passo.

O Ser autossuficiente, a própria consistência de sua definição linguageira, depende portanto do enigma em torno de sua existência; se ela fosse estabelecida, tudo o mais consistiria ou existiria nesse ser, seria nesse ser - sonho metalinguístico. A existência por si mesmo é indefinível mas intuível; não consiste em nada, pois, se consistisse, se fosse conceituável, não seria mais existência. Se uma coisa se reduz a outra, não é realmente existente, mas consistente, se encaixa numa escala conceitual, participa da deriva simbólica.

Quanto mais caracterizável é um conceito, menos extenso ele é; quanto mais específico, quanto mais restritivo a uma parte da realidade ele for, mais ele necessitará de definições de outros conceitos mais amplos. Ora, o conceito de ser é o mais extenso dos conceitos, pois abrange o maior número de seres (Morente, 1980); não há outro conceito mais amplo que o encerraria: que mais fundamental poderia ser o que simples e redundantemente é? Nada a dizer portanto do ser, impossível defini-lo, o que equivale a tudo poder ser atribuído a ele; qualquer predicado corresponde a nenhum predicado.

Dos objetos do mundo enquanto seres em sua estrutura própria e diretamente apreensível pela experiência, enquanto entes, portadores do ser, pode se dar a problematização de sua natureza, sua transformação em objetos do conhecimento, isto é, o trabalho ontológico propriamente dito. Na última lição de Encore, Lacan (1972-1973/2010) diz que a entidade do sujeito, que só pode se afirmar como pontualidade e evanescência, instantaneamente representado por um significante para outro significante, implica que seu "ser está sempre alhures, como o mostra o predicado" (p. 272).

O Ser seria uma exceção que determinaria a consistência do universo inautêntico dos outros seres, dependentes desta vastidão alhures, inatingível, mais abrangente que tudo, sempre Outra. A ex-sistência do conjunto de todos os conjuntos que poria o ultimato na conta da predicação, que estancaria a deriva que é a linguagem num universo, que daria o sentido da con-sistência de tudo; a própria estrutura da transferência, mediante a presença em ato do analista e da fórmula segundo a qual o sujeito é representado por um significante para Outro significante (Thibierge, 2007). 
Lacanianamente (1973/2003) a impossibilidade do ser, a falta-a-ser que é a metonímia desejante, implica que "o universo não está em outro lugar senão na causa do desejo" (p. 475). A heteridade do sexo (a) não estanca jamais a vacuidade do lugar do ser $\mathrm{S}(\mathbb{A})$, para usarmos um comentário de L'étourdit.

O descarnado do Um real sozinho faz portanto a mestria da ordem significante, entre o ainda do Ser e o trivial assinalamento de seu vazio. Nenhum predicado basta, o que faz do Ser a secção que Lacan (1972-1973/2010) anuncia na abertura de Encore, a ex-sistência do dizer formulada ao final desse seminário; um dizer a mais que jamais se fecha. Se o Ser é predicado, já é Outra coisa, estende seu limite mais ainda, prolongando a sustentação das pseudoessencializações provisórias, momentos existenciais de suposições de sujeito. Assim, como Lacan (1971-1972/2003) marca em ...ou pior, o Um se perde ao confinar a existência como o mais evasivo do enunciável, tal como sua correlativa aparência em que o Ser assina seus impasses lógicos.

\subsection{Concepção de mundo: a imposição da unidade}

Unidade e totalidade, categorias sinonímias ao ancoramento primeiro da filosofia, são exatamente o que Lacan visa obstinadamente destruir nestes seminários de 1971 a 1973. Háum e não-todo traduzem seu esforço em redizer que a "imposição do ser", a própria função da linguagem enquanto efeito de significado, é sonho fundador do conhecimento, que repousa sobre a suposição de uma realidade pré-discursiva. A crença de que o pensamento está separado das condições formais da linguagem ou que esta o reflete com perfeição, que o significante representa a si mesmo, designa uma coisa concretamente: "Não há nenhuma realidade prédiscursiva, cada realidade se funda e se define por um discurso" (Lacan, 1972-1973/2010, p. $98,115)$.

Não há metalinguagem, não há ser à parte, autossuficiente. Uma realidade prédiscursiva sustentaria uma metalinguagem do ser, identidade entre pensamento e verdade: "o ser é”, segundo a constante referência a Parmênides que Lacan (1972-1973/2010) faz. Ora, o dizer lacaniano é sobre "o que não há" (p. 240). O ser é "apenas um fato de dito", suposto enquanto "ficção de palavra", a partir da palavra, por exemplo "indivíduo", "substância", "eu” 
(p. 240). Assim, não há a "linguagem do ser", mas há a dit-mention do ser, de sua falta, porquanto “o simbólico só sustenta a ex-sistência” [itálico nosso] (p. 240, 241).

A metafísica dos gregos - diferentemente do idealismo moderno e heterogeneamente a Lacan —, buscou definir o ser em sua existência autônoma: o pensamento a contempla. A união inseparável entre existência e essência, que desde Parmênides estabelecia a equivalência entre o pensar e suas leis com o ser, passou pelo transcendentismo platônico e "desceu" ao mundo sensível com o realismo aristotélico, em que o conceito anda junto, atua sobre a materialidade das coisas.

Parmênides construiu sua solução metafísica em oposição a Heráclito e sua concepção do ser enquanto devir, o fluir da realidade. Ora, argumenta o filósofo de Eléia, uma coisa não pode ser e não ser ao mesmo tempo; se considerada como mutação permanente, ela deixa de ser algo para ser outra coisa enquanto também é o que deixou de ser. A contradição lógica resultante levou à tese parmenidiana fundamental, que posteriormente desembocou no princípio lógico de identidade: o ser é; o não ser não é. Parmênides deduziu portanto a identidade do ser enquanto a identidade entre o ser e o pensar: as propriedades da razão refletem, por sua cognoscibilidade mesma, as propriedades do ser, isto é, o pensamento racional é o ser. Resultam também do absurdo lógico constatado pelo filósofo as qualidades essenciais do ser: ele é único, eterno, imutável, ilimitado e imóvel, pois se fosse variável, temporal e espacialmente delimitável se revelaria irracional; sem a sua unicidade, o ser se chocaria com o não ser que, uma vez admitida a existência, anularia a coerência lógica da identidade mesma. Assim, o mundo sensível, que vai e vem, que se transforma, é aparência, ilusão, falsidade, e o mundo inteligível, que pode conhecer o ser, é autêntico.

Por sua exaustiva aplicação da razão na análise da realidade, por servir-se do princípio racional da identidade como diretriz do conhecimento do ser, para além da multiplicidade e da mutabilidade incoerentes e superficiais dos seres, isto é, por fundamentar-se na forma e não no conteúdo objetivo da realidade, a metafísica parmenidiana é de fato formalista. O molde da identificação, sem conteúdo, que Morente (1980) chama de "vício fundamental de todo eleatismo", também é detectável no sofisma de Zenão, discípulo de Parmênides, ao confundir as condições formais e lógicas do movimento com suas condições materiais (p. 85).

Para Platão, o erro fundamental de Parmênides foi confundir a existência da coisa material com sua unidade conceitual, isto é, coincidir aquilo que existe com a unidade de suas propriedades, conceber a autenticidade do mundo inteligível pela submissão do mundo sensível 
à lei da não contradição. Em outras palavras, Parmênides teria confundido existência e essência, ou consistência, conforme o vocabulário de Morente (1980). A teoria das ideias enquanto definição mesma de sua metafísica mescla uma teoria da existência com uma teoria da objetividade, propriamente sua ontologia. As "ideias" enquanto "visão" da intuição da coisa, portadoras de uma existência real no mundo inteligível, são o paradigma perfeito das coisas no mundo sensível, que são meras sombras passadiças e imperfeitas, são indiretamente, participando com as ideias. O conhecimento, dialético, pela discussão, argumentação e contraposição de teses, deve partir do mundo sensível à "unidade ontológica da significação" em que consiste o mundo suprassensível: "unidade ontológica daquilo que consiste, da essência, e, ao mesmo tempo, unidade existencial atrás dessa unidade ontológica” (p. 90).

Aristóteles, em oposição a seu mestre, injeta a inteligibilidade no mundo sensível, introduz a intuição na atividade dos sentidos. Conservando a ideia do ser como algo além do sensível, o verdadeiro ser, eterno, oposto à contingencialidade e à problematicidade do ser das coisas sensíveis, o estagirita todavia funde os dois mundos no conceito lato de substância, unidade existencial e consistencial. Assim, a coisa e seus predicados constituem a substância, que em seu sentido estrito designa somente a unidade que suporta todos os seus predicados, o que "jaz por baixo" [hipojeimenos]; "o correlato objetivo do sujeito na proposição, do sujeito no juízo", isto é, a objetivação da coisa a ser predicada, caracterizada (Morente, 1980, p. 98). A soma desses predicados, imprescindíveis para que a substância seja, constitui sua essência; acidente é o conjunto dos predicados que convém à coisa, mas se faltarem ela mantém sua essencialidade. O que existe são as substâncias individuais, e não seus conceitos, suas ideias, como era a metafísica platônica; os predicados não existem, são substâncias segundas, existências secundárias.

É difícil para um leitor disciplinado de Lacan conceber esses termos metafísicos enquanto materialidades qualitativas, individualidades verdadeiras, plenas e teleológicas. Aristóteles é o rival privilegiado de Lacan, observa Cassin (2013). Em seu "sistema" ou “concepção de mundo", sinônimos lacanianos para a ontologia, o sujeito da proposição é uma substância, unidade autêntica solidária a uma ética fundada numa suposição de saber único aos corpos, partes de uma totalidade cosmológica regida por uma supremacia essencial. Uma cosmologia, isto é, a "admissão de um mundo", consiste na limitação de um todo, "um ponto de vista, um olhar, uma tomada imaginária", cujo correlato é o ser enquanto eterno, "um 'um”," para além desse mundo do qual ele toma conhecimento, uma parte ex-sistente a ele: "como ele 
suportaria poder tomar conhecimento se, de um certo modo, ele não fosse “ex-sistente?" (Lacan, 1972-1973/2010, p. 96, 113, 147).

\subsection{Função do ser enquanto alma: a ética aristotélica segundo Lacan}

A existência parmenidiana enquanto algo a ser descoberto além do véu dos sentidos se atualiza em Aristóteles como substância, somada à ideia platônica agora imanente à realidade sensível: à informidade material soma-se o princípio atuante da forma, conferindo-lhe sentido e finalidade. Cada individualidade é designada, integralizada por uma essência. A variedade ideativa que Platão introduziu, a constelação de conceitos relacionados por outros tantos conceitos, está nas coisas sensíveis enquanto força informativa. Se para Parmênides havia o formalismo do ser em sua unicidade, para além da ilusão do mundo sensível, a metafísica aristotélica desembocará na primordialidade de uma causa imaterial, puramente inteligente e imóvel, puramente ato e pensamento, existência necessária cuja razão está em si mesma; o Bem, a esfera imóvel, imagem do bem dos seres menores. À sua necessidade se opõe a contingencialidade das coisas do mundo, sua mobilidade, seu ser e não ser sucessivos cuja realização só pode ser a própria atividade da existência absoluta de Deus, nada mais que pensamento de pensamento [noesis noeseos] que, por só ter como objeto do pensar a si mesmo, implica que tudo o mais seja produto seu. A existência necessária desse fundamento do próprio existir, a realidade como puro ato, provê a existência, a potência e a essência da totalidade do mundo.

Lacan (1972/1973/2010) retoma a Ética a Nicômaco para subverter a conformidade desse Ser Supremo, o Bem por excelência, com a noção aristotélica de alma: em latim, anima, lida como a animação correspondente à ambiguidade entre o objeto $a$ e o Outro, como na fórmula da fantasia: o agente, o sujeito, "toma o outro por sua alma" (p. 172). O Bem inalcançável, sempre Outro, se presta à confusão com os bens menores intermediários que constituem essa arquitetura de bens do método perfeccionista da ética aristotélica. Pelo hábito, minha pessoa deverá atingir esse Bem como se fosse natural, mesmo que se trate de uma construção virtuosa: o saber é o ato por excelência do corpo, diz Lacan; aqui se diferencia o

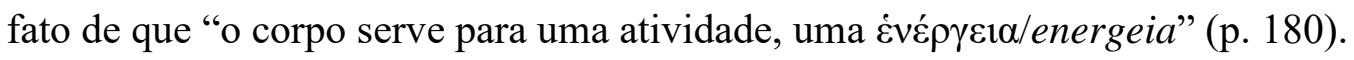


Sustentado pela substância que corresponde à alma, a natureza das coisas, o corpo deve encontrar sua realização ontológica, seu Bem; a causa final é imanente ao objeto, tal como no discurso do mestre o mais-de-gozar suporta o saber $\left(\mathrm{S}_{2} / a\right)$. Ora, a confusão que Lacan busca desfazer se dá entre a opacidade do gozo do Outro e o Ser Supremo: atingir o Bem confundido com os bens menores, o Ser como se fosse os seres menores cujo objetivo é sempre um "mais ser”. Entre o brilho de agalma e a radical opacidade do Outro, a função do discurso analítico é marcar a iminência do fracasso do dizer, pois "o sentido indica muito precisamente a direção na qual ele fracassa" (p. 168).

Assim, se dizer tudo é a forma masculina de malograr a relação sexual, o que se especulou na antiguidade como "o Bem do homem", pela coalescência de $a$ com S(A), se diferencia da relação mais próxima da mulher $(L a)$ com Deus, na medida em que "seu gozo é radicalmente Outro" (p. 173). Com esse gozo, designado por $\mathrm{S}(\mathbb{A})$, entende-se que "Deus ainda não saiu de cena" (p. 174).

Lacan (1972-1973/2010) diz que a finalidade de seu ensino é

... dissociar esse pequeno $a$ e esse grande A, reduzindo o primeiro ao que é do imaginário, e o outro, ao que é do simbólico. Que o simbólico seja o suporte do que foi feito Deus, está fora de dúvida; que o imaginário é o que é sustentado por esse reflexo do semelhante ao semelhante, é o que é certo" (p. 173)

A confusão que faz o objeto $a$ funcionar neste lugar de falha é a própria função da linguagem, enquanto significação e velamento, através da "função do ser" (p. 173). A psicanálise se distingue da psicologia porquanto descola, cinde essa soldagem; $a$ com $\mathrm{S}(\mathrm{A})$ fazem A, o saber suposto a ser encontrado, a Verdade da identidade.

Em outros termos, a questão do Outro gozo é uma questão sobre os limites do saber. O sujeito enfrenta o saber pelo qual ele "a(l)ma", isto é, pelo qual ele confunde o Outro com a causa de seu desejo. Se em algum lugar no Outro isso sabe, se se vive a pulsão a despeito da travessia da "fantasia radical" (Lacan, 1964, p. 149), isto é, se o sem sentido do rapport "não diminui em nada o interesse que devemos ter pelo outro" (Lacan, 1972-1973/2010, p. 179), é porque ainda se continua a supor o Bem, a alma: “em algum lugar, no Outro, isso sabe. Isso sabe, porque isso se sustenta justamente por esses significantes com os quais se constitui o sujeito" (p. 179).

A ilusão de que o Outro sabe é aquela que, na ética aristotélica, faz da esfera imóvel a suposição de nosso Bem, que deve seguir à sua imagem; a função do ser suporta-se pelo simbólico coalescido ao imaginário do corpo. A causa final do objeto estaria nele mesmo: "é 
difícil para quem 'alma' não pensar que tudo pelo mundo sabe o que tem a fazer” (p. 179). Na linha do discurso do mestre $\left(\mathrm{S}_{2} / a\right)$, a alma, a substância, é saber que sustenta a entelechia do corpo, sua realização, seu fim enquanto ser. Imputar uma alma às coisas faz do saber propriedade do corpo. Em contrapartida, a falha do discurso científico, $\mathrm{S}_{2} \diamond a$, descola o saber de seu Bem; não necessitamos mais saber a finalidade da natureza das coisas, o saber não é essência do objeto.

A psicanálise não é portanto uma cosmologia pois advém do discurso científico. A desarticulação do saber em relação ao objeto corresponde à desarticulação da fantasia, que supostamente detém a causa final. É a ambiguidade do inconsciente: suposto como um saber a mais sobre o sujeito, mas esse saber tem limites; no entanto basta que sonhemos para que a fantasia nos restitua a alma, perfeitamente a(1)mável (Lacan, 1972-1973/2010).

A alma é o pensamento, que é fantasia e gozo, e não a identidade do ser: "o pensamento é gozo"; "somos enganados [joués] pelo gozo", somos gozados [jouis]; "o que traz o discurso analítico é o que já estava esboçado na filosofia 'do ser' (entre aspas), ou seja, que há gozo do ser" (Lacan, 1972-1973/2010, p. 147). Entre Aristóteles e Freud, as fórmulas "densas" e “difíceis" que Lacan (1972-1973/2010) formula e qualifica em 8 de maio de 1973 expressam as radicalizações do saber e da verdade que desembocaram na subversão ontológica que propõe: “o inconsciente não é que o ser pense", conforme a ciência aristotélica, "o inconsciente . . é que o ser, falando, goze. . . . e não queira saber nada, mais nada disso. . . . não saber nada de nada" (p. 224). Em outras palavras, o pensado [le pensé] não é reflexo do pensamento [la pensée]; o ser não pensa, o ser fala, diz tolices [bêtise]: que se fale, se goza, e o único saber que importa é o acefalismo da letra; “o homem já sabe tudo o que ele tem a saber” (p. 224).

A dit-mention do gozo fálico tem como lei a repetição: é o dizer de Freud, equivalente à ausência do rapport. Trieb é “a deriva do gozo” (p. 232).

Essa hiância inscrita no próprio estatuto do gozo, enquanto dit-mention do corpo, isso no ser falante, é o que reaparece com Freud, através desse teste ... que é a existência da palavra (parole). Onde isso fala, isso goza. O que não quer dizer que isso saiba alguma coisa, porque, de todo modo, até segunda ordem, o inconsciente não nos revelou nada sobre a fisiologia do sistema nervoso, não? (Lacan, 1972-1973/2010, p. 235)

O sujeito se barre $^{3}$ : a causação do gozo pelo significante faz o corpo pulsional, não o “corpo fechado" (p. 229). O corpo funda o ser tanto para Aristóteles quanto para Lacan (19721973/2010). A diferença entre eles é a diferença das fórmulas acima. Para o estagirita o homem

\footnotetext{
${ }^{3}$ Forma pronominal do verbo barrer que tem o sentido de "cair fora", "se mandar".
} 
pensa com sua alma, com os mecanismos que se supõem ao funcionamento corporal, ou seja, o corpo é o próprio pensar. Le manche $\left.e^{4} \mathrm{~S}_{1}\right)$ unifica a parcialidade pulsional na ideia de alma, que representa a unidade e a singularidade do devir corporal. A alma é o que se pensa $\left(\mathrm{S}_{2}\right)$ sobre o corpo sob o comando do pensamento do manche $\left(\mathrm{S}_{1}\right)$ : é sua identidade suposta cujo conteúdo o explica.

O corpo que se move basta para que lhe atribuamos seus "milagres" (Lacan, 19721973/2010, p. 229). Para a psicanálise, radicalmente não parmenidiana, a estrutura do pensamento repousa na estrutura da linguagem. Não se trata de qualquer estruturalismo, adverte Lacan, mas da linguagem habitada por uma inércia, comparável às constantes matemáticas da física, cuja formalização transmite integralmente letras. A primazia é do escrito, que todavia é transmitido com a linguagem em seu efeito primário, de significado, o que produz seus malentendidos.

A busca do Bem corresponde, na verdade, à pulsionalidade. Não há conhecimento, diz Lacan (1972-1973/2010); a metaforização aristotélica é a metáfora da significação fálica que tenta dar um sentido ao objeto perdido. Chegamos no encontro "almoroso" sem a verdade do semblante das almas da copulação; o Outro, um buraco, resta desviado dos pedaços de gozo: “O Outro, enquanto lugar onde a palavra (parole), por ser depositada . . . funda a verdade e, com ela, o pacto que faz suplência à inexistência da relação sexual, na medida em que ele seria pensado, pensamento, pensável” (Lacan, 1972-1973/2010, p. 234).

Suposição de alteridade traduzida como desígnio espiritual, renovação do dizer confundida com realização ética, objetivação teleológica refletida no mundo como razão de ser, fundar-se-ia num discurso que não seria da ordem do semblante.

\subsection{Inexistência, existência, ex-sistência, insistência}

A crítica lacaniana do essencialismo filosófico encontra na interrogação lógica das matemáticas "vias que sejam rigorosas" para sustentar o real contra a realidade fantasística do

\footnotetext{
${ }^{4} \mathrm{O}$ substantivo masculino "le manche" designa o cabo de um instrumento ou ferramenta. "Du côté du manche" significa "do lado mais forte, daquele que dirige, que tem todas as vantagens", segundo o Larousse (2021).
} 
mundo admitido (Lacan, 1971-1972/1997, p. 53). Demorou para que a existência fosse extraída da essência, comenta Lacan, que anuncia por todos os cantos de seus seminários 19 a primazia que Frege e Cantor gozam em sua fundamentação do Um como emblema da existência.

Lacan serve-se do esforço fregeano em dar um estatuto puramente formal à questão do número, que recusa qualquer psicologização e qualquer empirismo na consideração das dificuldades proposicionais em lidar com seu próprio domínio material, prenhe de paradoxos. A teoria dos conjuntos, a escrita matemática, seu uso das letras como demarcação de impasses lógicos, obstáculo semântico, é a única via encontrada para abordar o real.

A existência do Um é matemática. Lacan (1971-1972/1997) repete que o número faz parte do real, tanto quanto as pretendidas identidades sexuais: "Não sabemos nada de real sobre estes homens e estas mulheres como tais, pois é disso que se trata; não se trata de cães e de cadelas" (p. 35).

A tese que sustenta a fratura ontológica desenvolvida neste período é que a linguagem só funciona, reflexivamente, pela dialetização da presença e da ausência que decorre da existência de sua objetividade. A instituição simbólica trabalha em si mesma e projeta fenômenos de verdade e falsidade segundo o fato mesmo de sua materialidade, neutralidade do som falado. Se só o discurso pode fundar realidades, é a existência de sua estrutura, como efeito de escrito, que deve ser responsabilizada por estarmos em falta quanto à determinação de nossa "natureza".

É como se Lacan respondesse a Parmênides: é porque há o significante que o ser é e o não ser não é. Mas há uma diferença radical, que atravessa esses seminários. Para o mestre de Eléia, precursor do princípio de identidade que busca legitimar sua metalinguagem, o ser é o princípio de organização onipresente no mundo, incluída aí a razão que se alimenta dessa certeza formal de que uma coisa é, e jamais poderia não ser, pela simples redundância de que o que é é, se não for mais, se tiver que se haver com o tempo e o espaço, com limites, bordas, terá que levantar a questão do que não é, não é mais, não será, não é aqui, não é lá; e uma vez admitido que há o que não é, cairíamos na irracionalidade e no erro: só pode haver, e ponto final; não haver está fora de cogitação existencial, porquanto é mera declinação do que é.

O real lacaniano não é o "fora" fobicamente dispensado por Parmênides, precisamente como noção mesma, haja visto que o ser estaria em risco se estivesse espacialmente implicado. Se o ser é e o não ser não é, no nível do discurso, é o efeito de significado da linguagem que decide pela identidade enquanto suporte instantâneo ao imaginário. Queriam os gregos a ex- 
sistência de um exterior ao caos dos sentidos que assegurasse os benefícios do Um entendido como container do bom-senso, da razão, da totalidade da ideia das coisas, do acabamento obsessivo da existência em si mesma, suporte de seus dramas míticos.

É pelo outro efeito da linguagem, simultâneo à significação, que Lacan diz ser possível demonstrar o real como índice da impossibilidade que sustenta a própria necessidade lógica do discurso. O efeito de escrito, cujas letras revelam uma gramática e não um sentido, permite à psicanálise assinalar o que rompe a copulação ontológica exercida pelo verbo e produz a divisão do sujeito no gozo. Não é fácil dizer o que se escreve, diz Lacan, pois "o que se escreve é a letra" (p. 117). Ler não nos obriga a compreender - "o escrito não é para ser compreendido" (p. 100) —; o escrito matemático, a teoria dos conjuntos, é o suporte, a orientação para o discurso analítico tirar o que lhe cabe quanto à função da linguagem, para que ele tenha efeitos e possa "sustentar e completar os outros discursos" (p. 119).

O que se escreve e existe são unidades — fabricações humanas: "há Um para o animal?" (Lacan, 1971-1972/1997, p. 91) — ocas de sentido mas carregadas de gozo, interrogação do Um correlata à enigmatização do saber. Na medida em que existe o escrito, a necessidade lógica de sua presença se dá tanto quanto a suposição da inexistência, ainda [encore], de seu valor. Diz Lacan (1971-1972/2003): "Não há existência senão sobre o fundo de inexistência e inversamente, ex-sistere, não tirar sua sustentação senão de um fora que não é. É disto mesmo que se trata no Um" (p. 95).

O trecho não poderia ser mais enigmático, reflexo do que justamente transmite ${ }^{5}$. Ora, na medida em que a metalinguagem está fora de questão e que abandonamos qualquer subsistência do mundo enquanto tal, é no nível das elucubrações do sujeito que devemos demarcar o ponto em que a fantasia e suas condições lógicas se cruzam, onde o parentesco entre o mito e a lógica demonstra que um corrige o outro (Lacan, 1971-1972/2003).

A suposição de inexistência, exercício de uma unidade real que constitui a própria condição do assentamento semântico-gramatical, é consequência da produção da necessidade, do fato de que o que está escrito exige uma fundamentação. O exterior não é, precisa Lacan, estamos nos maus lençóis do simbólico, que só pode sustentar a contradição de suas peças, a instalação da mesmidade da diferença como a própria exibição da indeterminabilidade de seu suporte. Não que o "fora” que não é não seja porque há um "dentro" que é (carência de significado): o que existe insiste pois ex-siste seu fundamento; o que insiste é a ex-sistência da

\footnotetext{
${ }^{5}$ Os capítulos 2 e 4 trazem outros comentários que ajudam a esclarecer o trecho.
} 
definição de sua certeza substancial. O que é pelo logos é engodo próprio ao conceito, esquecimento necessário da contradição que faz o vivido; o ser é negação, recusa, esquiva, alheamento, não advento: não como imperativo racional — o não ser não pode ser —, mas como corrupção inerente à identificação simbólica, vaporização existencial significante infinita. A inexistência do referente é atividade do sujeito que repete sua dupla resposta — a verdade e o gozo - como suposição de uma antecedência mítico-lógica para sua necessidade em lidar com o que o torna presa no discurso.

Criticando "vertentes metafísicas diversas" porquanto "não nos interessa, em nenhum grau, a maneira com a qual o Um se ilustra”, Lacan (1971-1972/1997, p. 102) afirma que o gozo só funciona como inexistência: ele é condição de verdade do falo como coordenação do semblante; a falta implica que não falta significante para abraçá-la em seu poder de significação.

O Um inventa o Ser enquanto dizer que visa ser verdadeiro, mas o nega na medida em que o cercamento da verdade a ser atingida, contraposta à insuficiência de seu semi-dito, não a faz nem mais nem menos verdade; se ela falta, é o verídico que se atesta enquanto faltosidade mesma do "além da linguagem", universo que não seria aparência. O que falta, simbolizado matematicamente pelo número 0 , não nega, por sua pretendida autenticidade perdida, a existência do símbolo que o designa; a falta é o produto mesmo da interrogação simbólica que Lacan (1972-1973/2003) chama de gozo, necessidade de discurso pela qual "vêm a ex-sistir aqueles que insistem na repetição" (p. 548).

Por isso o número é tão convocado como pertencente ao real, demonstração lógicomatemática de que é do impossível que advém os dramas da certeza, da unidade e da multidão de seres e sua enumerabilidade.

\subsection{Impossível e necessário: o equívoco do gozo Um}

A discussão sobre o gozo, vê-se, é ontológica: a ausência da predicabilidade que fundaria essências, proporcionalidades conjugáveis numa relação logicamente determinável, o fato de que a linguagem não é espelho da pré-discursividade que copularia com seus respectivos significantes, de que ela não abriga Uns portadores de qualidades, atributos e funções naturais, conceitualizáveis em classes próprias — a depender do que colheríamos nessa "manjedoura da 
metafisica" (Lacan, 1972-1973/2010, p. 134) —, isto é, a inessencialidade do ser, seu não ser, anda junto (pare-ser) com a necessidade de sua falta.

... quando se trata do verdadeiro impossível, do impossível que se demonstra, do impossível tal como se articula - e isto, certamente, leva tempo - entre os primeiros garranchos que permitiram o nascimento de uma lógica com o auxílio do questionamento da língua, e também o fato de haverem percebido que esses garranchos encontravam algo que existia, mas não do modo que se acreditava até então, à maneira do ser, isto é, daquilo que cada um de vocês se crê, se crê ser, sob pretexto de que vocês são indivíduos. Percebeu-se que havia coisas que existiam nesse sentido de constituírem o limite do que pode resistir ao avanço da articulação de um discurso. É isso o real. (Lacan, 1971-1972/2003, p. 81)

A falha ontológica não cessa de se "ex-crever", como buraco, como Um ex-sistente, suposição de ser que sustenta as ficções utilizáveis ${ }^{6}$, para o gozo, das palavras. O impossível é a outra face do necessário, em implicação recíproca: "que o não ser não seja, isso é posto pela palavra na conta do ser, que tem a culpa $[$ faute $]$. . . de que o não ser não seja . . . se o ser não existisse, estaríamos bem mais tranquilos com essa questão do ser” (pp. 134-135).

A distinção entre existência e essência é crucial para que Lacan possa criticar a suposição do ser permitindo todavia que sua ficcionalidade siga com a dignidade de efeito de estrutura. Efeito de significado e efeito de escrito participam, respectivamente, da aspirada essencialização do ser alhures e da evanescência de sua significância protética. $O$ não ser não é, pois está em falta fatal com o significante; ele não é tanto quanto o ser "é", isto é, sua inessencialidade é essencial ao uso gozoso da linguagem, ao aparelhar a realidade com qualidades que no entanto lhe ex-sistem. A outra satisfação, promovida pelo significante, visa um Outro gozo, cuja inominabilidade transcende a provisoriedade da existência e suas imaginarizações: encore.

Isto é, encore é a própria repercussão da impossibilidade na existência, o relançamento necessário de sua negação no infinito. No lado esquerdo das fórmulas da sexuação, a universal antifilosófica que Lacan propõe em $\forall x . \Phi x$ engloba tão somente a própria opacidade de princípio do significante, conjunto que se fecha por aquilo que nele não pode entrar: "ao menos um", "correlato do vazio do Outro" pela expectativa de sua unidade simbólica, "aposta", "requisito desesperado", "gratuito", "referência", "esperança de rapport", "transcendência da captura da função fálica", que portanto "escapa à castração", "limite", "borda", "complemento" do "Um sozinho", "lugar de Uma falta"; em $\exists x$., unir e negar, uniar [unier], são a mesma coisa: encore.

\footnotetext{
${ }^{6}$ A referência é a Theory of fictions de Jeremy Bentham.
} 
O gozo fálico é a necessidade "que torna possível a existência do homem como valor sexual" (Lacan, 1971-1972/2003, p. 43). Aqui nos referimos ao tributo simbólico ao Um para exercer a significância, o que Lacan (1971-1972/2003) chama de "homem"; a possibilidade de se distinguir pela seriação do traço que o diferencia, sem que isso implique atributo: o próprio funcionamento da linguagem enquanto suposição de ser que tampona a perda que ela instaura. O sério como serial, da série de Uns que ocupam a mesma falta, que Lacan (1972-1973/2010) opõe à comicidade das concepções de mundo. $\mathrm{O}$ assassinato do Pai mítico de Totem e tabu iguala-se a 0 , no seminário 18 , pois não se trata de um "reflexo patriarcal", mas da abordagem lógica da castração (Lacan, 1971, p. 106).

O fato de haver Um povoa a ficcionalidade gozosa do semblante com a inadequação permanente de suas narrativas, muito embora o que também corresponda ao "homem", para Lacan, seja a crença, correlata à idiotice de seu gozo. A suposição da inexistência preliminar ao necessário é a própria atestação da existência do inconsciente e dos rodeios sintomáticos que insistem em restituir à pulsão uma verdade já vencida: esse "andar sem sair do lugar que se designa como saída para a existência" (Lacan, 1971-1972/2003, p. 48).

Um dizer que a função fálica não é verdade é a necessidade da existência da contradição como condição do exercício da unitarização e da totalização. É o ponto em que Lacan declara seu antiaristotelismo radical, ao fazer da negação e da indecisão a motivação fundamental da estandardização semântica. Acreditar no sentido não pode deixar de andar junto com a descrença em seu parceiro, o sentido contrário: o que se apresenta como embate de ideias é a própria unicidade do impasse formal do simbólico, que só pode ser símbolo do rasgo interno de sua materialidade, seu desgarramento fundamental ao que o imaginário lhe injeta como visão individualizante das entidades do mundo. A inexistência de apoio da suposta realidade, vivida como falta, irrompe na representação nos avatares da ausência, da inferioridade, do incompreensível, do falso... do feminino; mas são de fato a necessária contraposição conceitual do que se afirma como presença verídica, que exige se defender do retorno da anulação de sua adesivação lógica. A certeza só pode existir tendo como par a sombra de seu desmentido.

A univocidade do sentido é o que sustenta o princípio da não contradição: uma palavra não pode, simultaneamente, ter mais que um sentido. O mundo é estruturado como a linguagem, e os entes são feitos como os sentidos que lhe dão sua suposta essência. Se as mitologias da multitude não passam de renovação infinita da falta que se duplica necessariamente como verdade e falsidade, acima e abaixo, forte e fraco, energia e fatiga, ter e não ter, ser e não ser, enfim, o dualismo que organiza o situar-se da fantasia, é porque a qualitatividade ôntica do 
mundo é tratamento do equívoco intrínseco ao instrumento de sua avaliação; desvios semânticos que parecem propriedades mas são contagens do mesmo. Corpos são contáveis, mas sexos, não, observa Dolar (2012).

Com Lacan a homonímia faz com que o sentido só possa ser equívoco; significação, em vez do sentido aristotélico dotado de unicidade; ab-senso, portanto. Para que serve o gozo, pergunta inicial de Encore? Lacan supera Aristóteles, segundo Cassin (in Badiou \& Cassin, 2013), na medida em que este se restringiu pela não contradição, pela decisão de sentido. Fazer do paradoxo a condição do sentido é outra postura; transcendentaliza no inconsciente a oposição verdadeiro-falso porquanto não visa desfazer o equívoco. Lacan explicita essa estrutura, fazendo o lugar do sofista necessário na origem do princípio de não contradição, enquanto Aristóteles afastou essa necessidade, da exceção que faz a regra, do um que não para que a lógica funcione. A não contradição se funda na contradição.

Formalmente, é o decaído oposto ao todo, sob a égide do Um que protocoliza a matéria significante como espectro que se encarna nos fechamentos de sentido, supostos contornos das partes de um todo corporal. Semanticamente, o mal-estar de não ser senão pelo símbolo faz dessa negação espectral a habitação do falso, parceiro do verdadeiro, em cujo jogo os valores podem se alternar conforme a decisão de sentido obrigar o conforto de sua crença.

Essa exceção é a função inclusiva: o que enunciar do universal, senão que o universal seja cercado precisamente pela possibilidade negativa? Exatamente, a existência aqui desempenha o papel do complemento ou, para falar mais matematicamente, da borda. E é isso que inclui o seguinte, que há em algum lugar um todo $x$ que se torna exatamente um pequeno $a$ - quero dizer um A invertido em $\forall a$, cada vez que ele se encarna naquilo que se pode chamar Um ser, pelo menos que não se coloque senão como ser e principalmente a título de homem. (Lacan, 1971-1972/1997, p. 124)

A particular máxima se apoia na contradição, diferentemente da particular mínima em que Aristóteles fez da existência a confirmação da essência: o que limita o universal é, formalmente, o fato de que o derradeiro significado está elidido do simbólico; como se fossem conceitos opostos ou equívocos para a mesma palavra, na linha da filosofia antiga. O sujeito fica à mercê do dito, diz Lacan (1973/2003) em L 'étourdit. Sua exceção faz a não proporção e a não relação por ser o confronto do semidito da verdade com o saber, que, radicalmente, escapa mesmo à própria esperança do ao menos Um que a fala insinua em seu gozo de semblante.

Se a má norma macho acredita, o feminino se lhe opõe enquanto hora da verdade que disjunta gozo e semblante (Lacan, 1971). 


\subsection{O Um, o Outro e o Ser}

Excetuar-se à função da castração, colocando ao pé do muro da linguagem o molde de uma unidade a se afirmar como identidade, prevê que o verdadeiro realize a copulação do corpo com a nomenclatura que o particularizaria, reflexo de seu assinalamento pelo traço que o faria candidato a conceito, pluralizável por analogia com o que é cada coisa no mundo, cada um e cada uma simetricamente aptos para fazer o casamento da sex ratio. Negar, unir e significar fazem portanto a bricolagem sintomática nossa de cada dia, velamento linguageiro básico que institui as almas, os seres do mundo à nossa imagem e semelhança. Os outros e eu, mesma realidade que a necessidade lógica repete enquanto gramática do discurso e produção de significado, visando a menor besteira. A objetivação de si e do outro precisa supor que o que Um significante representa para Outro significante confirma e realiza a quadratura de um universo mensurável, livre de ambiguidades.

O lugar do Outro é portanto o índice da não inscrição do Um, fato de que a unidade é a própria falha ontológica que a linguagem é obrigada a carregar por simplesmente funcionar: uma existência no processo, na passagem, sempre no entre-dois, uma multiplicidade não unificante, que exige a retomada do dizer, persistência da desproporção entre o que é dito e $o$ que isso quer dizer. O buraco delimitado é seu próprio fracasso, pois o esforço de significar a si mesmo consigo mesmo não conclui seu gozar de fazer semblante, tal como Lacan (1971) define a verdade: sustentada por essa inacessibilidade, a aparência de ser encontra em seu maisde-gozar a produção de seu limite e de sua deriva. A repetição da mesmidade da diferença, paradoxo que define o significante, implica que o Outro seja o tratamento impossível de seu significar: Outra materialidade que efetivamente copulasse, fundisse, sem ser a paródia do verbo de ligação.

Não há rapport porque não há Outro. A elucubração de saber que cria nós tentando se desembaraçar do enigma dos afetos que alíngua suscita, equívoco do equívoco, sustenta-se na hipótese de sujeito suposta a qualquer copulação verbal (Lacan, 1972-1973/2010). O indivíduo falante confunde-se aí com outra coisa, não significante, que é feita sujeito: não o corpo enquanto paraíso perdido, mas corpo enquanto demonstração de impasse da polivalência da palavra, despedaçamento do sexual que desloca a fundamentação da experiência vivida. A perda, a desidentificação radical que repete a esperança de proporção e relação entre o que se articula, faz a reciprocidade total entre o sujeito e o que uma demanda supõe de vazio, o objeto 
$a$ — "correlatos de palavra de gozo, enquanto gozo de palavra" —, conforme Lacan (19721973/2010, p. 251) termina Encore.

Entre cada significante e o próximo, a objetivação escorregadia faz o sujeito hiante em seu saber ontológico, dizer que fabula a realidade da fantasia, conforme Lacan (19711972/2003) termina ...ou pior. O lugar da alteridade epistêmica que essencializaria a suposta substância do que aparentemente existe $\left(\mathrm{S}_{1} \rightarrow \mathrm{S}_{2}\right)$, à moda aristotélica, escapa tanto quanto a natureza do indivíduo proposicional: "Isso nos explica que, durante tanto tempo, o sujeito tenha podido crer que o mundo sabia tanto quanto ele" (Lacan, 1972-1973/2010, p. 251).

Esse vazio instituído é correlato à dimensão de verdade que a fala inscreve, porquanto sua função é gozar de si como corpo (Lacan, 1971-1972/1997). A unitarização desse saber se “Outropõe" [s'Autreposer] porque "não é isso": a mestria que o Um instaura é esforço oposto ao indeterminado da experiência, que supostamente apela à resolução pelas condições formais da linguagem (Lacan, 1971-1972, 1973/2003). Yad'lun, que em francês se exprime pelo partitivo, traz o eco do informe no sem-lugar que a unidade carrega por ser regime cognitivo, e não descoberta, tradução ou eleição. "Existe algo da ordem do Um”, "Há alguma coisa do Um, sobre o Um”, mas não "Há $o$ Um”, como Lacan (1971-1972/2003) não deixa de comentar.

Por isso existir é depender do Outro, o Outro significante, da concretização ontológica, que se esvanece por ex-sistir (Lacan, 1971-1972/1997). O Um se articula a despeito do não Um que se declina como diferença, irracionalidade, não cabimento, pois não lhe cabe, é desproporção que só pode se repetir na retomada unária da simbolização; Um a mais que é Outro a menos. O Outro do gozo efetivo, resta proibido, inter-dito, aquele cuja linguagem que o cria só lhe permite a habitação ao lhe fornecer "escafandros", diz Lacan (1971); "do Outro, goza-se mentalmente" (Lacan, 1971-1972/2003). O real constitui um "limite eletivamente imaginarizado sob a forma do enclausuramento", comenta Soler (2005, p. 228).

O sonho de alcançar o Outro, veremos a seguir, é o quadro da sexuação: o sexo, o gozo do corpo do Outro, tem a ver com a diferença, e o discurso analítico decanta a escrita desse abismo; o amor tem a ver com o mesmo, por isso é recíproco, imposição de ser do discurso do mestre. Não há proporcionalidade enunciável: que se negue $[\text { nia }]^{7}$ a universalidade da castração $(\exists x . \overline{\Phi x})$, não há $[n y a]$ complemento encontrável fora dela $(\overline{\exists x} \overline{\Phi x})$. Inter-dita, a relação é o real enquanto resposta que estimula a repetição de sua escrita; a resposta reproduz a pergunta. $\mathrm{O}$

\footnotetext{
${ }^{7}$ Nia é o passado simples do verbo nier (negar) conjugado na terceira pessoa (ao menos um) do singular.
} 
dito não vai sem o dizer, não vai sozinho, busca formar um par com aquilo que radicalmente lhe escapa: o parceiro do Um é o $a$-morfismo que o introduz enquanto elucubração, que o suporta no não toda que impede o fechamento da universalidade como senso-absexo. A heterossexualidade é a lida com a não secundariedade, a ex-sistência do dizer que rescinde o sentido e implica a insaciabilidade do amor: encore é a falha de onde a demanda repete a heterogenia entre o Um e o Ser.

O feminino, resto que exige a contagem de sua própria mesmidade de diferença, o não Um que faz o indecidível entre a conclusão pelo Um e a realização no alheamento, é o Outro, não confundido com sua falta, que é suplemento, diz Lacan (1971-1972/2003): “A mulher, a verdadeira, a mulherzinha, esconde-se atrás dessa falta mesma. É um refinamento, aliás, absoluta e plenamente conforme ao que nos ensina o inconsciente, de somente obter pleno êxito ao fracassar" (p. 14). A plenitude falida do Um é sua própria fragilidade como não Um que se desloca alternativamente mas abdica do binômio dentro/fora que responde pelo enclausuramento da totalização; o Outro do Um não é falta nem presença, é o que responde por sua indeterminação; é o excesso em cujo entorno o racional trabalha ad infinitum, engajando o sujeito no dizer.

Não cessar de não se escrever é falta para o que se decide a despeito da negação que o afirma. A contradição de base do significante destaca-se contra "algo que não tem forma", tentando formatar no sentido o que escapa a sua estrutura (Lacan, 1971-1972/2003, p. 89); não como conteúdo mas como condição de sua gramática, que deposita em suas letras a promessa de ir ao encontro do Outro, o que seria a metalinguagem. A ex-sistência do ser é sua discordância com o saber, o que faz da formalização de sua impossibilidade também ex-sistente, porquanto ela também se sustenta num dizer; o dizer da língua, que é chamada a explicá-la. A escrita matemática, sublinhadíssima como exemplo por Lacan (1972-1973/2010), é a substituição do funcionamento de um número qualquer de Uns pela letra: escreve-se integralmente, contando-se sem que a identidade designe outra coisa que sua própria lei.

Assim, Cassin (2013) precisa que a "gigantomaquia principal” entre Lacan e Aristóteles se define pela mudança do princípio de todos os princípios: "não há contradição" deve ser aturdido por "não há relação sexual” (p. 29). De regulação da linguagem a vergonha, a ontologia esvazia-se no ponto crítico do equívoco e da escrita, por onde o discurso analítico produz o absenso do sexo e sustenta a ambiguidade fundamental e intratável que comanda o sentido. Isto é: uma alíngua como a qual o inconsciente é estruturado, depósito e persistência dos equívocos cuja intraduzibilidade é inadmissível no paradigma aristotélico, que desambigua distinguindo 
sentidos, alocando-os a palavras próprias. O que dizer de alíngua senão a monotonia do real de que não há rapport, ficção do Dois?

\subsection{Ontologia lacaniana?}

Entre o ser e o não ser Lacan coloca o paradoxo do "mais, ainda" como indecisão fundante do sentido, retorno da recusa que o próprio saber estabelece contraditoriamente como determinação de seu processo. Ex-siste o que insiste como falha que o significante faz operar ao por em marcha a diferença, a força e a fraqueza do que a fala lança como verdade, dandonos o sentimento de que somos alguma coisa: aparência e impasse arrematam o nó da fantasia fundamental. A ambiguidade que define o termo "pare-ser" [parêtre] representa aquela da significação, pois o ser que se demonstra nos paradoxos dos efeitos de escrito (para-), como impossível, se situa também na própria decisão que esquece essa ex-sistência na aparência de ser (para-ser, parecer).

O reconhecimento da irresolução no coração da necessidade lógica reflete-se na postura ziguezagueante de Lacan em relação à ontologia: ele tem ou não tem uma? A psicanálise se sustenta foracluindo a filosofia? Um saber que se constrói, sempre em referência a outro, subsiste imune a ele? Faz-se original, como Outro? O que ganharia a psicanálise ao se declarar antifilosófica, se isso é possível? O discurso analítico é um metadiscurso?

Em 1964 Lacan tinha uma ontologia, "como todo mundo" (1964/1988, p. 73). Entre 1971 e 1973, oscilações. A “unologia” se opõe à ontologia, que é mera "careta do Um”, uma "vergonha" própria à "manjedoura universitária", onde não faltam "o sentido e a verdade"; seria portanto "muito engraçado" que houvesse uma ontologia, pois o discurso analítico "não apenas não é ontológico mas... não é filosófico"; ele demonstra o que não recorre "jamais a nenhuma substância, por não se referir jamais a nenhum ser, por estar em ruptura, por esse fato, como que quer que se enuncie como filosofia".

Mesmo assim o ser é definido com sua respectiva substância gozante. Na sétima aula de Encore, Lacan (1972-1973/2010) diz que a "honestidade" faz com que "seja em linha pontilhada ... que são postos, envolvendo todos os meus enunciados, os nomes dos principais filósofos em cuja ontologia mais geral eu inseriria meu pretenso sistema" (p. 147). Coerente 
com a secção de predicado que definiu o ser na primeira lição, Lacan agora se insere pontilhadamente no campo geral da ontologia: a recusa à adesão, uma espécie de não todo na sistematização, faz desse ser o "ser da significância", cuja "razão" é o gozo do corpo (p. 148).

Os comentadores atualizam a dificuldade manifesta no ensino de Lacan.

Badiou (1980) aborda a solução lacaniana sobre o ser durante o seminário 11, a partir da questão de Jacques-Alain Miller sobre qual seria a ontologia do inconsciente: "tenho minha ontologia - por que não?", mas esse discurso "não tem de modo algum a pretensão de cobrir todo o campo da experiência” [itálico nosso] (Lacan, 1964/1988, p. 73). Dois meses depois a causa inconsciente não é definida nem como ente, nem como não ente, mas "um $\mu$ ท́ ồ, da interdição que leva um ente ao ser, malgrado seu não-advento, ela é uma função do impossível sobre a qual se funda uma certeza" (p. 124). Nem uma concepção de mundo, nem filosofia, a psicanálise é uma "visada particular que é historicamente definida pela elaboração da noção de sujeito. Ela coloca esta noção de maneira nova, reconduzindo o sujeito à sua dependência significante” (Lacan, 1964/1988, p. 78). Badiou (1980) aí encontra acesso à ontologia ao definir o inconsciente como "o ser que subverte a oposição metafísica do ser e do não ser", pois "ele é efeito da falta-a-ser" [tradução nossa] (p. 152).

Efeito da falta, inventora de sua própria negação. A verdade, desde então "mutilada", implica uma retificação da filosofia como um todo (Badiou, 1980, p. 156). Zupančič (2008) sustenta aí a ruptura fundamental entre a psicanálise e a filosofia, embora considere essa “íntima” heterogeneidade a partir de que "a psicanálise não é ontologia” (Zupančič, 2012, p. 3). O inconsciente designa um problema, e não a verdade (sexual) escondida; seu antagonismo é a ruptura de sua representação, mais ou menos distorcida, não um problema de representação: representar já indica um problema. O sexual portanto é essa falha ontológica fundamentalmente material, e não um fragmento intocado da realidade objetiva uma vez distorcido e que deve ser finalmente reconhecido como ele "“realmente é"” (p. 17). Para a filósofa, a sexualidade se opõe à ontologia na diferença entre o ser e o real, a única diferença que há, a oposição que subjaz à simbolização: o real é o impasse do ser; só há ser no simbólico, mas há o real, que não é o "lado de fora" do ser, seu além, é "a própria curvatura do espaço do ser", sua contradição inerente: "o real é a pedra no sapato [bone in the throat] de cada ontologia", é o que as ontologias tradicionais tiveram que eliminar para poder falar de "ser qua ser" (p. 8).

Outra filósofa, Cassin (2013) considera que a relação entre performance e significante define a "sofística lacaniana", na medida em que o ab-senso, o "nome do Real por diferença 
com a ontologia”, ocupa o lugar dessa relação (p. 55, 56). O avanço portanto está no abaristotelismo, que vai mais longe que o fora-do-sentido do sofista aristotélico: o sentido transforma-se em não sentido, "não sentido no sentido . . lacanismo que faz tremer verdadeiramente o mundo do homem até a raiz" (Cassin, 2017, pp. 211-212). O sentido afunda, e o gozo feminino, assim como o objeto $a$, ajudam Lacan a manifestar a mudança de princípio. A verdade intragável só é "menorizada" como merece com o fechamento da ronda dos discursos pela psicanálise, presença do sofista em nossa época; com a sustentação da inapreensibilidade objetal ligada "ao significante do significante e ao que não há se houvesse": um "blá-blá-blá de falasser" ciente de seu não ser que "parecé" pela metade, menos mestre, menos filósofo, que "não procura foder a verdade, incomível de toda maneira" (pp. 211, 212).

Safatle (2007), por outro lado, considera que a reformulação lacaniana da teoria das pulsões revela-se uma ontologia negativa: "uma ontologia fundada no reconhecimento da irredutibilidade ontológica da negação” (p. 150). Mais exatamente, trata-se da transformação da negação constitutiva da pulsão de morte em negação ontológica, segundo o monismo pulsional que suporta a essencialidade da clínica psicanalítica. "Noção ontológica absolutamente central”, a pulsão, no singular, para Lacan (1959-1960, p. 88), articula a contradição inerente ao trabalho simbólico, entre ligação e desligamento, aglutinação imaginária derivada da unidade sintética do Eu e potência de negação da linguagem, que vai contra essa coerência representacional narcísica, enquanto automatismo de repetição da cadeia significante. A ilusão de realidade da representação recusa a realidade ontológica da negação, isto é, o caráter puramente diferencial do significante enquanto marcação do desencaixe fundamental entre palavra e coisa; a morte simbólica como satisfação própria à pulsão de morte, quando o significante revela o apagamento de seu referente.

Apagamento que não significa ausência, mas justamente o contrário: a negação não é instanciação de um não ser, privação, expulsão, inércia do vazio puro, fora, sem relação com a determinação. A crítica lacaniana da positivação do objeto na determinação do desejo, passo fundamental para o desdobramento de seu tratamento da teoria pulsional, implica que a falta-aser seja um "modo ontológico de presença do que há de essencial em objetos da experiência" (Safatle, 2007, p. 183). O valor ontológico da negação está na presença do que resta não identificável simbolicamente e "se oferece como determinação essencial de objetos não mais constituídos como imagens narcísicas" [itálico nosso] (p. 178). Manifestação da essência que é a "autonegação da identidade" (p. 183): essencialidade da negatividade, e não essencialidade conceitual, conforme a tradição ontológica de noções como substância e identidade. 
Alinha-se aqui a crítica que Dunker (2019) realiza sobre o que considera "idealismo do significante", tendência pós-lacaniana ao idealismo metafísico que separa o ser enquanto produção de sentido de um não ser enquanto inexistência do "fora da linguagem" (p. 97). Analogamente, a oposição é aquela entre o ser do logos e o falso ser dos sentidos, o ser que é e o nada. Ora, argumenta o autor, o cerne da ontologia lacaniana está na sobredeterminação e na função de causa do referente negativo, que em vez de desontologizar a psicanálise distingue sua postura ontológica como crítica à metafísica da identidade. O zero, a falta, o vazio, o real: o não ser aqui entendido como porvir impossível é uma figura ontológica da negatividade, não uma inexistência da extensão, do sujeito ou do corpo. Haveria uma pretensão metafísica ao opô-la ao ser do significado, que, por anular o não ser como ausência, se esqueceria da especificidade epistemológica da psicanálise, que fixa o real, que nos afeta, como impossível no próprio paradoxo temporal do negativo; não a existência do significante oposta à inexistência do exterior ao discurso, mas a implicação ontológica própria à materialidade significante: “A função de causalidade, a estrutura de encontro do objeto $a$, assim como a estrutura de porvir da verdade existem, ainda que não se realizem na articulação significante. Observe-se aqui a razão de tantos enganos dos que insistem em pensar o Real sem o tempo" (p. 99).

Dunker (2019) segue portanto Safatle (2007) ao definir a ontologia lacaniana como ontologia negativa, que não é o mesmo que uma ausência de ontologia; mais uma crítica à universalidade (e à particularidade), ao conceito, à identidade, à unidade e à não contradição do que uma definição do ser. Compromisso ontológico que portanto transpassa as fronteiras epistemológicas, razão pela qual é problemático querer separar psicanálise e filosofia quanto à discussão ontológica; sem falar na incorporação de temas historicamente filosóficos pela psicanálise lacaniana, como "sujeito", “objeto", "verdade”, “existência”, "universal”. Aqui o pensamento de Dunker (2019) é frontalmente contrário à leitura de Cevasco (2013), a título de exemplo, para quem Lacan teria se afastado "de toda ontologia", sua compreensão da linguagem estaria "desontologizada", e o discurso analítico se constitui como "uma antifilosofia" (p. 95, 98).

A filosofia não se reduz à metafísica, que por seu turno não se reduz à ontologia. Pela consideração do papel decisivo da metafísica na histórica da filosofia, que também comporta sua crítica, pode-se apreciar onde a problemática ontológica define compromissos e exibe diferenças; onde há dominância metafísica na questão propriamente ontológica, e onde esta não se confunde com aquela. As afirmações categóricas de Lacan sobre a relação entre filosofia e discurso do mestre não devem portanto equivaler a filosofia à metafísica e à ontologia enquanto 
sistema positivante unificado do ser reduzido ao fazer sentido. "É importante não confundir a crítica da metafísica de Aristóteles com a recusa da ontologia. O programa de "esvaziamento do ser" presume uma ontologia, ainda que esta não seja a ontologia eleata" (Dunker, 2019, p. 96). Assim,

Lacan fala do ser do sujeito, da insondável decisão do ser (a escolha da neurose), do ser de gozo, do ser do homem (que não pode ser compreendido sem sua loucura), do ser de linguagem (que o torna homem), das paixões do ser, sem falar na gramática de oposições entre o não ser e o não pensar (que caracteriza o ato psicanalítico). Isso sem mencionar o "momento ontológico da angústia". Há muitas coisas presumidas na expressão "consistência do ser". Seu inverso pode implicar sua não necessidade (contingência), sua carência de unidade (divisão), sua não identidade (multiplicidade) sua perda ou ausência (alienação) e finalmente sua não particularidade ou universalidade (singular). (p. 96)

As três propriedades básicas da metafísica da identidade, que historicamente suportaram os debates sobre a unidade ou a multiplicidade do ser, são a reflexividade, a transitividade e a simetria, lista o psicanalista. A corrupção epistemológica dessas referências constitui a própria negatividade da ontologia lacaniana:

Quando Lacan fala da diferença sexual ele o faz de três maneiras distintas (1) como irreflexividade entre os semblantes ou shifters "homem" e "mulher", (2) como ausência de transitividade entre o gozo do lado homem (fálico) e o gozo do lado mulher (não-todo fálico) e também como (3) dissimetria entre a mulher tomada como objeto $a$ e sintoma no fantasma masculino e o homem tomado como devastação e como falo na mítica feminina. Esta crítica da identidade ocasiona uma perturbação do entendimento metafísico tradicional de unidade: não se trata de duas substâncias (ousia, substância ou essência), mas de uma dupla maneira de não ser: não-ser-um (ao menos-um) e não ser Outro (não-uma-que não). (Dunker, 2019, p. 102)

É portanto nas teses lacanianas sobre a sexuação que o debate chega ao auge, o que explica a grande disparidade de opiniões entre comentadores, observa Dunker (2019). Faz-se portanto mais que necessária a discussão ontológica colocada no centro do estudo da sexualidade em Lacan, o que então significa evitarmos “os contornos metafísicos do pior”, isto é, o pretenso fechamento epistemológico da psicanálise a despeito do atravessamento da ciência e da filosofia na discussão empreendida por Lacan (p. 105).

Safatle (2007) conclui que essa complexa articulação entre clínica e ontologia é uma das principais contribuições lacanianas. Por que relacionar psicanálise e ontologia? Isto é, "que tipo de ontologia seria capaz de fornecer, à psicanálise, os subsídios implicados na direção do tratamento?" (p. 151). Apoiando-se na tortuosidade do debate no ensino de Lacan e na consideração badiouana do ser do inconsciente como subversão ontológica, Safatle (2007) argumenta sobre a "realidade ontológica das experiências de negação", do que "bloqueia o esgotamento do ser em uma determinação positiva" (p. 175). Assim, a pulsão de morte — no grupo conceitual da angústia e do fenômeno do Unheimlichkeit, enquanto experiências subjetivas de abalo da ordenação imaginária do mundo e de si mesmo — constitui com Lacan 
uma teoria do negativo própria à clínica psicanalítica. A auto-objetivação subjetiva para além da sintetização objetiva imaginária (narcísica), isto é, a possibilidade de o sujeito se reconhecer na negação determinante dos objetos pulsionais, constitui o caminho da análise.

A admissão da negatividade como produto próprio das condições formais da linguagem é um posicionamento ontológico, que é a própria discussão da fundamentação e da objetivação em geral, lembra Dunker (2019). Parece-nos portanto problemático situar a psicanálise fora da universalidade desse impasse, pois sugeriria, apesar da declaração contrária, a desconsideração de que a malha epistêmica que constitui os saberes é o exercício da própria inversão simbólica nas situações protoverídicas que produz. Isto é, se é justamente isso que se denuncia em psicanálise, a função do impossível pela qual se funda a marcação de um impasse sob a aparência de uma certeza, por que o que se produziu desde Freud não seria também um estabelecimento de estatuto da fundamentação em si? Certo, não o que "é”" mas como não se é, o que já é dizer sobre "ser".

A auto-oposição que o gozo instaura no vivente falante não é outra coisa que o tratamento de noções clássicas e fundamentais na filosofia e em qualquer outra atividade pensante que um dia a humanidade já pôs em exercício. A unidade, a universalidade, a existência, a parte, o conjunto, o continente da ausência: a sexuação é a própria função paradoxal que a linguagem funda como matéria bruta do equívoco, recuo fundamental ao inteligível, e contradição semântica que não faz mais que reverberar essa opacidade; regência muda enquanto organização do sentido a despeito do efeito da falta que introduz; não a falta, mas o que ela altera na estruturação mesma que idealiza: a alteridade radical do que a descompleta naquilo que ela se propõe — não mais faltar —; é onde a ignorância se barra mas causa, sem "razão de ser" (Lacan, 1971-1972/2003, p. 177). Não todo é como Lacan o diz. 


\section{2 "Homem" e "mulher" entre 0 e 1}

Os seminários simultâneos que Lacan realizou entre 1971 e 1972, O saber do psicanalista e ...ou pior, interrogam incessantemente a capacidade da linguagem de semiproduzir verdade e sua incapacidade de escrever o Dois: o impasse da existência. Epistemologicamente, o problema é homólogo ao estatuto lógico do número, pertencente ao real. A lógica e a matemática ganham primeiro plano nas demonstrações, orbitando em torno do seguinte "alvo" (Lacan, 1971-1972/2003, p. 61): o que se transfere de 0 para 1?

Essa “encrenca” (p. 61) terá como resposta o aforismo Yad'lun, que significa: não há relação do Um com o Ser, do Um com o Outro, isto é, não há rapport sexual. O questionamento do simbólico pelo simbólico reflete o buraco pelo qual a forma contradiz a indeterminação e onde a indeterminação subverte a pseudopluralidade da representação. Cada significante contradiz os que o rodeiam mas é ao mesmo tempo contradito por si mesmo, por indispor de conteúdo para dialetizar. A monotonia desta oposição, a demonstração de impossibilidade chamada de real, desponta na dualidade imanente às produções simbólicas: negativo-positivo, verdadeiro-falso, fálico-castrado. Como diz Lacan (1971-1972/1997), "homem” e "mulher”, 2 no simbólico, não por atributo mas como o exercício mesmo da oposição que o significante instaura na produção de significado.

Dedicamos este capítulo para demonstrar como Lacan constrói esse raciocínio marcando sua heterogeneidade em relação ao pensamento aristotélico e sua concordância com a teoria dos conjuntos, desembocando no fundamento da diferença (sexual) segundo o discurso analítico e nas respectivas fórmulas quânticas (da sexuação). 


\subsection{Yad'lun, uma unidade sem forma}

O xis da questão é o sujeito — o mesmo $x$ de $\Phi x-$, que se parafraseia facilmente como variável aparente, furo do significante, hiância, fileira de pensamentos, falo, lugar do semblante, conjunto vazio, Um, gozo Um, real do Um sozinho, Um real. Por todos os lados, Lacan (19711972/1197, 1971-1972/2003) busca enfatizar a unariedade da engrenagem simbólica, fundada no vazio que circula enquanto produção de verdade. Essa é a base das quatro proposições quânticas que visam escrever a impossibilidade de escrever a relação sexual para o ser falante: escrita da inconsistência linguageira, cujo referente é sua própria indeterminação. A existência, portanto, está para o real; assim como o significante está para a falta.

O paralelo entre a teoria do significante e a interrogação lógico-matemática do número é anunciado em várias lições: “o número faz parte do Real” (Lacan, 1971-1972/2003, p. 18). Isto é, em qualquer domínio do saber, a referência do que é simbolizado é a própria ausência de objeto a ser simbolizado, o que justamente impulsiona a simbolização. É nesse sentido que Lacan (1971-1972/2003, p. 25) logo postula, em 15 de dezembro de 1971: “O Real é o que comanda toda a função da significância”.

Assim, o $x$ da questão é o que vem a ser um homem ou uma mulher, vazio do sujeito no argumento da função. Lacan (1971-1972/2003, p. 61) também diz que é a "propriedade comum" da logicização da sequência dos números inteiros segundo Frege: o que se transfere de 0 para 1 e impede que haja, não multiplicidade, mas tão somente repetição.

O Um como unidade formal desabrigada de compromissos metafísicos adveio com a tardia interrogação lógica das matemáticas, "questão que é central quanto à verdade" (Lacan, 1971-1972/1997, p.120). Lacan chama a atenção para o que chama de "extravagâncias do número", isto é, a descoberta, decepcionante para os gregos, dos números irracionais (aloga) e sua incompatibilidade com a unidade — "algo que sai do campo do Um" (Lacan, 19711972/2003, p. 104).

Banidos do pensamento aristotélico, os irracionais tiveram sua existência decretada por Platão, que embora não rompesse com a ordem pitagórica e os promovesse à categoria de número, reconheceu-os como um não-ser que teria qualidades concretas, haja vista sua fácil determinação geométrica; mas eles não se relacionavam com os números inteiros (arithmoi). 
Le Gaufey (2014) lembra que uma não relação deve ser pensada segundo a ordem simbólica vigente: o discurso se estabelece por suas próprias coerções, e aquilo que não se inscreve, como no caso dos irracionais, pode não deixar de ter efeitos. De fato, foram séculos de debates e tentativas de aproximação até os aloga serem legitimamente reconhecidos como números e fazerem parte dos números reais ${ }^{8}$.

Lacan (1971-1972/2003) critica a metafísica aristotélica, tributária da noção de indivíduo que se vê nas particulares e universais (aquelas são ilustrativas destas, seu conceito; elas não entram em contradição) de seu quadrado lógico. A perspectiva do número pela suposta afirmação empírica é portanto recusada. O Parmênides, de Platão — "lacaniano" mas "um pouco débil”, Frege e Cantor são as referências principais: há uma “distância” entre a existência logicamente determinada e a "existência natural" (p. 101).

Lacan (1971-1972/2003) traz "a questão da emergência do 1 como tal” a partir de Frege e sua interrogação da gênese lógica do número: não se trata a fundo "da série dos números inteiros, mas da possibilidade da repetição. A repetição se coloca a princípio como repetição do 1, enquanto 1 da inexistência" (p. 53, 58).

Frege buscou fundamentar a aritmética a partir de argumentos puramente lógicos. Partindo do conceito (primário) de equinumericidade, isto é, a correspondência biunívoca entre objetos (extensões de conceitos), estabeleceu que os números são essas igualdades de extensões de conceitos (secundários), sem qualquer referência à contagem de objetos físicos ou abstratos: “O número não é algo físico nem, tão-pouco [sic], subjectivo [sic]; ele não consiste de todo numa representação"; o número cardinal é "o sentido de uma igualdade numérica" (Frege, 1884/1992, p. 74, 83). Enquanto Peano trabalhara o zero e o sucessor pela via dos axiomas, o sistema fregeano se constitui por verdades analíticas. Com efeito, seu livro Os fundamentos da aritmética inicia-se com a indagação sobre “o que é o número um” (Frege, 1884/1992, p. 29).

Para forjá-lo, será necessário formular em que consiste o número zero, que, por sua vez, cai sob o conceito "desigual a si mesmo", a rigor a extensão dos conjuntos equinuméricos a esse conceito ${ }^{9}$. Ora, como nenhum objeto pode ser desigual a si mesmo, o que seria a própria demonstração de contradição lógica, a tal conceito se atribui uma extensão vazia, inexistente.

\footnotetext{
${ }^{8} \mathrm{O}$ próximo capítulo debruçar-se-á inteiramente sobre a questão, articulada à noção topológica de compacidade.

9 "O número cardinal que vem para o conceito F é a extensão do conceito 'equinumérico ao conceito F”" (Frege, 1884/1992, p. 87).
} 
A sagacidade de Frege está em postular tal objeto contraditório que, em seguida, lhe servirá para estabelecer o conceito "igual a zero", sob o qual cairá o objeto número um ${ }^{10}$ : "esta conquista permanece para nós preciosa na medida em que nos dá o 1 como sendo essencialmente . . o significante da inexistência” (Lacan, 1971-1972/2003, p. 55). O 1 conta o fato único da contradição que o zero encarna em sua inexistência; sua autodesidentidade satisfaz o protocolo fregeano do número pela igualdade porque é a desigualdade em si mesma, como noção, que se determina como Uma.

A geração da cardinalidade se funda paradoxalmente na contagem do que a nega; $a$ regra da igualdade está enraizada em sua exceção; ela é o envolvimento de sua própria anulação. O zero, sob o princípio de identidade que a racionalidade exige, torna-se igual a si mesmo para fundar o um: por assim dizer, tem sua contradição lógica "resolvida" e trans-formase ambiguamente em objeto, enquanto elemento do conjunto que constitui a extensão dos conceitos equinuméricos ao conceito "igual a 0 ".

O objeto que faz o número 1 , a possibilidade de unitarização em si mesma, é o envelopamento da própria impossibilidade de sua constituição. Ele encarna a irresolução do 0 por ser a própria objetificação de sua indeterminabilidade: $\{0\}$. O número sucessor, dependente da gestação dos antecedentes, bebe na ambiguidade que desagua entre 0 e $1^{11}$.

Frege "gerou o Um do conjunto vazio ... para instaurar que zero e um são dois", isto é, é do "1 que falta no nível do 0 (zero) que procede toda a série aritmética" (Lacan, 19721973/2003, p. 544; 1971-1972/2003, p. 93). Ao número 2 advirá o conceito “igual a 0 ou 1”, e assim por diante. A repetição começa então, diz Lacan, na terceira unidade, quando o vazio do zero é contado pela segunda vez, o que, portanto, inaugura a repetição dessa contagem da inexistência no seio da sequência ${ }^{12}$.

A lição de 19 de janeiro de 1972 de ...ou pior é categórica em nos esclarecer esse ponto: a inexistência advém da existência do significante, isto é, inexistir não é não existir propriamente, não se trata de um nada, mas é precisamente existir através do símbolo que constitui a inexistência. Ponto paradoxal e essencial para entender a ausência de fundamento

\footnotetext{
${ }^{10} \mathrm{O}$ próximo subcapítulo retomará este processo com mais detalhamento.

11 Reevocamos ao leitor a enigmática passagem que comentamos brevemente no primeiro capítulo: "Não há existência senão sobre o fundo de inexistência e inversamente, ex-sistere, não tirar sua sustentação senão de um fora que não é. É disto mesmo que se trata no Um" (Lacan, 1971-1972/2003, p. 95).

${ }^{12}$ Em termos conjuntistas: "0 é o número que vem para $\emptyset$ (“diferente de si próprio"); 1 é o número que vem para $\{0\}$, ou $\{\varnothing\}$ (“igual a 0 ”); 2 é o número que vem para $\{0,1\}$, ou $\{\varnothing,\{\varnothing\}\}$ ("igual a 0 ou 1"); 3 é o número que vem para $\{0,1,2\},\{\varnothing,\{\varnothing\},\{\varnothing,\{\varnothing\}\}\}$ (“igual a 0,1 ou 2 "), e assim por diante" (Rona, 2010, p. 126).
} 
empírico ou psicológico do logicismo fregeano. Afinal, o zero, entre não existir enquanto objeto e se tornar uma inexistência para permitir a fabricação da sucessão dos inteiros, é essa mesma ambiguidade da ex-sistência que interessa a Lacan, duplicidade da noção de inexistência (a localização da falta como lugar e o fato de seu não advento); a constatação da própria inconsistência simbólica em seu regime de unitarização. Uma falta impreenchível por ser a própria afirmação da impossibilidade mesma de determinação da unidade: $\exists x . \overline{\Phi x}, \exists x . \overline{\Phi x}$.

Em relação à teoria dos conjuntos, Lacan (1971-1972/2003) diz que essa inacessibilidade do 2 se produz no nível do álef zero, o primeiro dos cardinais infinitos, a cardinalidade que constitui o conjunto de todos os números naturais. O apoio está em formulações de Gödel sobre o conceito de inacessibilidade, não sem incorrer em imprecisão matemática em favor dos propósitos de formalizar a não relação.

O Dois não pode ser alcançado pela linguagem pois ela só reproduz a determinação do indeterminado que o zero transmite ao um, infinitizando a busca pela identidade pela desigualdade única que dá forma à unidade significante. O leitor pode encontrar discussões mais detalhadas em Badiou (2008), Rona (2013) e Le Gaufey (2014). Aqui vale extrair da inacessibilidade em questão que o (gozo) feminino é infinito enquanto "uma ficção útil para manter o pensamento finito do sujeito" [tradução nossa] (Badiou, 2008, p. 226); que "abstrações não impedem o trabalho matemático, dos matemáticos ou do inconsciente", e suas “consequências são sensíveis, e consideráveis" (Rona, 2013, p. 163); e que "em cada ocasião, o infinito faz sua entrada mais ou menos discreta não para manifestar alguma classe de enormidade ou de imensidade com que o imaginário comum se deleita sob tal termo"13 [tradução nossa] (Le Gaufey, 2014, p. 136).

Ao proclamar Yad'lun, trata-se de mostrar em que "essa forma de se exprimir" se mostra de acordo com o que "historicamente é produzido na teoria, a teoria dos conjuntos" (Lacan, 1971-1972/2003, p. 98). A lição de 15 de março de 1972, intitulada "capítulo geral do Uniano" (p. 96), paga tributo à distinção entre "é Um" e "o Um ê" (p. 85), no Parmênides, para lançar o aforismo do seminário: "renovamos a dialética platônica" (p. 95). O equívoco do zero, também chamado de "bifididade do Um" (Lacan, 1971-1972, p. 88), corresponde ao que o analista deve introduzir na experiência, visto que "ele preside nessa bizarra assimilação de Eros ao que tende a aglutinar” (p. 86). A divisão de que se trata é correlata à divisão do sujeito - entre Uns que

\footnotetext{
${ }^{13}$ Como bem observa Le Gaufey (2014), a infinitude dos números que compõem a decimalidade de um número irracional implica, ao contrário do que o esforço em alcançá-la pode acabar supondo, um valor absoluto modesto: $\pi$ seguirá sendo "três e migalhas" (p. 136).
} 
são negados em sua própria determinação formal; e a falsa união de Eros, o Dois da fantasia, é denunciada pela impossibilidade de inscrição do Um, que "existe senão por não ser", no Outro (p. 96).

O Um diz, mas não pensa, almeja ser verdadeiro; a demarcação de seu lugar é o próprio eco de sua vacância inexorável, que só faz afirmar a invariabilidade de seu impossível: "será que não lhes chama a atenção . . . que eu fale do Um como de um Real, de um Real que também pode não ter nada a ver com qualquer realidade?”(Lacan, 1971-1972/2003, p. 101).

Por esse motivo, Lacan também supõe a existência de uma origem comum à linguagem, já que "todos" e "alguns" não são exclusivos a algumas línguas, são instâncias homólogas do mesmo processo de simbolização; não tributárias, portanto, de uma ordem quantitativa que supostamente presidiria à emergência da linguagem e do número. A discussão aqui é com Aristóteles e seu quadrado lógico pela particular mínima: para o estagirita, a existência individual do ser se atesta na própria presença do pronome, enquanto que Lacan opta pelo quadrado da particular máxima e pela distinção da existência em relação ao ser, o que, entre outras vantagens, o permitirá escrever as fórmulas do lado mulher. Com efeito, se a existência é pensada como a materialidade corporal do indivíduo, como conceber um não todos ao mesmo tempo em que não há quem não se submeta à função? Pois é justamente "o que a lógica aristotélica elude” (Lacan, 1971-1972/2003, p. 10): “Aristóteles imagina que basta dizer que alguns, alguns apenas, não todos, são assim ou assado para que isso os distinga; que é distinguindo-os daquilo que, ele é assim, se estas não o são, por exemplo, isso basta para assegurar sua existência" (p. 95). É precisamente a formulação da ex-sistência que permite a articulação modal entre as fórmulas quânticas.

Assim, haver Um "não é evidente" (Lacan, 1971-1972/2003, p. 100). À tagarelice da associação livre Lacan faz corresponder o Um, que fala, o que implica que a associação não é livre mas ligada. Nota-se, pois, a correlação da verdade, em sua condição de só poder ser meiodita, com o significante em si, isto é, enquanto seu próprio desdobramento: a verdade "não é outra coisa senão esta articulação" (p. 117).

Quando o Um se articula, destaca-se exatamente isto: não há dois. Eu lhes disse, isto é um dizer. Vocês podem até encontrar aí, ao alcance da mão, a confirmação do que digo quando digo que a verdade só pode meio-dizer. Basta vocês decomporem a formulação. Para dizer isso, ele só pode dizer, ou bem há - e, como digo eu, Há-um —, ou bem não dois, o que se interpreta imediatamente por nós: não existe relação sexual. (Lacan, 1971-1972/1997, p. 177) 


\subsection{0 sujeito e a verdade}

Já no seminário Problemas cruciais para a psicanálise se fermentava a ideia de uma "nova lógica” a ser constituída (Lacan, 1964-1965/2006, p. 159). Lacan lá fazia forte apelo ao estreitamento das relações entre psicanálise e lógica, sublinhando suas dificuldades análogas e a utilidade dessa disciplina em interrogar as regras da análise. Seu ensino já vinha estabelecendo uma "lógica da falta", convocada nessa lição a se instalar "no nível das diversas formas mais ou menos enganosas da identificação", isto é, no nível do sujeito e do objeto a (Lacan, 19641965/2006, p. 159). A referência a Frege é crucial nesse seminário, visando alargar a compreensão da questão do traço unário. O status do Um deve ser, portanto, situado especificamente no domínio da aritmética: “A psicanálise é uma lógica e, inversamente, podese dizer que a lógica tem muito a esclarecer-se com certas questões radicais que são colocadas na psicanálise" (p. 158).

A partir de alguns seminários fechados realizados na época, Lacan (1964-1965/2006, p. 177) conclui: "o sujeito seria, em suma, reconhecível naquilo que se revela, no pensamento matemático, estritamente ligado ao conceito de falta, a este conceito cujo número é zero". Aproximação realizada por diversas vias ao longo dos seminários 19. Explicitamente, no final de $O$ saber do psicanalista, Lacan traça a homologia entre o conjunto vazio (a inexistência) e o sujeito:

\footnotetext{
O modo do pensamento, na medida em que é, se posso dizer, subvertido pela falta da relação sexual, pensa e só pensa por meio do Um. O Universal é esse algo que resulta do envolvimento de um certo campo por algo que é da ordem do Um, salvo que a verdadeira significação da noção do conjunto é precisamente que o conjunto é a notação matemática desse ... \$, o sujeito enquanto não é nada mais do que o efeito de significante, dito de outro modo, o que eu represento: um significante para um outro significante.

O conjunto é a maneira com a qual, num giro da história, as pessoas menos capacitadas para esclarecer o que concerne ao sujeito, aí se acharam, se podemos dizer, necessitadas. O conjunto não é nada mais que o sujeito. É exatamente por isso que não se poderia sequer manejá-lo sem a adição do conjunto vazio [Ø]. [itálicos nossos] (Lacan, 1971-1972/1997, p. 126)
}

Segundo a teoria dos conjuntos, o conjunto vazio está contido em todos os outros conjuntos, sendo a base da própria teoria. Trata-se da autonomia do simbólico que interessa a Lacan, que faz uso do triângulo de Pascal em algumas lições para demonstrar a reiteração do Um. Assim, ao dizer que o sujeito é o conjunto, marca-se, tal como no seminário 12, que ele é 
essa falta que circula e promove a simbolização, sendo o Um ilustrado na figura de "um saco furado" 14 .

Cada significante, correlato a um conjunto, é o Um, repetitivo, cuja solidão é a repercussão da própria contradição que a necessidade lógica recusa, mas é a única fonte de seu fazer. O necessário o é porque sua condição de existência é o impossível. No esquema fregeano, a fundação do 1 já é a formação desse furo aludido por Lacan: demarcado o que resta incongruente com os valores lógicos de verdade, esta se certifica na unidade pela monotonia da inexistência que a fôrma negativa do Um arrasta nas fachadas da contagem; o 1 sucessor do 0 vale-se de progredir seu absurdo lógico na sucessão, pois é o próprio contorno do impossível como única condição formal para as possibilidades de conjuntização.

O que existe é o significante, diz Lacan (1971-1972/2003), que também precisa que só o Um existe: o equívoco da existência é a afirmação repetitiva de Uma desidentidade.

Por esse motivo, no resumo do seminário ...ou pior, Lacan (1972-1973/2003) dirá que o Um ocupa o lugar do semblante:

O significante Um não é um significante entre outros, e supera aquilo pelo qual é apenas pelo entre-dois desses significantes que o sujeito pode ser suposto, segundo eu digo.

Mas é nisso que reconheço que esse Um-aí é tão-somente o saber superior ao sujeito, ou seja, inconsciente, na medida em que ele se manifesta como ex-sistente - o saber, digo, de um real do Um todo-só [Untout-seul], totalmente sozinho, todo-só onde se diria a relação. (p. 547)

O Um tout seul não copula com o Outro, pois não pode constituí-lo; assim como o corpo imaginário não faz relação com o significante produzindo uma suposta essência sexual: o Um enquanto lugar do semblante é esse furo do saco unário em que o sujeito se vê representado. A existência está situada, suportada pelo real, que determina a significância: o $x$ só é variável pelo valor de verdade que lhe atribuirmos na função; o argumento é $\varnothing$, que Lacan chama de sujeito, unidade suposta que se desfaz por estar implicada na disformidade que paradoxalmente a forma, a inexistência que constitui sua existência instável, a autocontradição que se afirma como única coisa a ser representada.

Fileira de pensamentos correlata à evanescência do falo, o "gozo Um" que "exerce a função do sujeito" (p. 548) é, portanto, castração. Isto é, o $x$ não varia porque é a unicidade da própria ex-sistência, a indeterminabilidade que fracassa toda empresa narcísica: "não há outra

\footnotetext{
14 "É a partir do que se refere ao lugar em que se faz um buraco, desse algo que, se vocês quiserem uma figura, representaria como sendo o fundamento do Yad'lun; não pode haver [d]o Um senão na figura de um saco, que é um saco furado. . . . eis o fundamento original, a ser tomado intuitivamente, do Um" (Lacan, 1971-1972/2003, p. 108).
} 
existência do $U m$ senão a existência matemática. . . . um argumento que é completamente esvaziado de sentido, é simplesmente o Um como Um" (Lacan, 1971-1972/2003, p. 132).

A aproximação entre psicanálise e interrogação lógica da matemática se dá no questionamento da existência, cuja primazia se articula ao interesse em compreender gramaticalmente como se produz a verdade como função, como esse lugar consegue se estabelecer, sendo apenas a própria articulação significante (ou conjuntista, na perspectiva matemática): negligencia-se seu conteúdo, visa-se à estruturação (defectiva) do sentido.

Dentre os seminários fechados de 1964-1965, Jacques-Alain Miller apresentou, em 24 de fevereiro de 1965, a fundamentação da homologia entre o sujeito e o zero, na medida em que ambos estão ausentes do campo da verdade, mas são o que justamente permite que ele se sustente: faltam à cadeia simbólica, mas mesmo assim lhe pertencem. A isso chamou de "sutura" em um artigo publicado posteriormente, baseado nessa apresentação: "Sutura, por extensão, a relação em geral da ausência com a estrutura da qual ela é elemento, na medida em que ela implica a posição de um 'lugar-tenente"” (Miller, 1967, p. 212). Apreciada com veemência por Lacan, consideramos que essa exposição é pertinente em nos orientar na leitura dos seminários dos anos de 1970.

Segundo o discurso logicista fregeano, o que faz a sequência dos números inteiros naturais progredir é a função do sujeito, que desconhecidamente opera em sua gênese (Miller in Lacan, 1964-1965/2006). Asserção paradoxal, pois é a exclusão mesma do sujeito que a aparição do número visa; o sujeito psicológico nomeador, ficcionista, das teorias empiristas.

Miller (in Lacan, 1964-1965/2006) faz uma leitura um tanto distorcida de Frege na medida em que concebe seu sistema fundamental, onde se relacionam o conceito, o objeto e o número, sob o prisma de uma relação de identidade entre conceitos, e não pela atribuição do número segundo a equinumericidade entre extensões de conceitos, como precisa Rona (2010). Entretanto, trata-se mesmo, na organização do sistema, da centralidade do princípio de igualdade enquanto chave para o domínio propriamente lógico.

Sob o conceito cai a unicidade da coisa, e não a coisa em si. O que é importante extrair disso é que o objeto é uma unidade, identidade que advém da subsunção a um conceito ${ }^{15}$ : “O fundamento do sistema de Frege está, pois, em apontar a função da identidade como aquela que

\footnotetext{
${ }^{15}$ A rigor, conforme a exposição fregeana, o idêntico advém como igualdade entre objetos que caem sob o conceito primário da equinumericidade, isto é, compartilham biunivocamente a mesma extensão.
} 
efetua a transformação de toda coisa em objeto, em deixar-lhe tão somente a determinação de sua unidade" (Miller in Lacan, 1964-1965/2006, p. 166).

O número se define, portanto, como unidade distintiva nomeada, idêntica a si mesma. A identidade fregeana, segundo Miller (in Lacan, 1964-1965/2006), inspira-se na definição de Leibniz: o idêntico se substitui, salvaguardada a verdade, que, no discurso de Frege, logicista, está ainda mais vulnerável. Não se trata da coisa, como vimos, mas de sua passagem a objeto. Miller (in Lacan, 1964-1965/2006) precisa que a dimensão da verdade é o que permite que a identidade em si mesma funcione.

A transposição do zero ao campo da verdade, paradoxo do sistema fregeano, condensa o que Miller (in Lacan, 1964-1965/2006, p. 163) chama de "lógica do significante", sinônimo de lógica geral, pois se trata do funcionamento formal, elementar de todos os saberes: "O que interessa é que se convençam que o lógico, como o linguista, no seu nível, sutura. E, do mesmo modo, quem diz 'eu"” (Miller, 1967, p. 213).

O zero "sutura" o discurso lógico por suas duas facetas, enquanto ausência e enquanto é contado como Um (Miller in Lacan, 1964-1965/2006, p. 170). A verdade deve ser sustentada: se o zero cai sob o conceito do desigual a si mesmo, número contraditório por ser falta de objeto, é justamente para que a verdade se mantenha. Se houvesse objeto sob esse conceito, subverterse-ia seu campo, segue Miller (in Lacan, 1964-1965/2006). Rechaça-se esse objeto para que ele sirva como índice de exclusão, incongruente com o verídico. Por outro lado, o zero é contado como Um, converte-se em objeto para fundar o número 1 . Sob o princípio da identidade, a ausência ganha unicidade.

Desse modo, quando o zero emerge ao campo da verdade, que é o campo do sentido, vai-se do Nome ao significante; isto é, como o registro da verdade é onde opera a identidade, conjugação do signo enquanto um significante se liga a um significado na formação de uma frase, a passagem da falta de objeto à identidade desse vazio a si mesmo, fazendo nascer o objeto, inaugura a significação: “a função que a identidade assume é o que permite que as coisas do mundo recebam seu status de significante” (Miller in Lacan, 1964-1965/2006, p. 166).

O zero é, portanto, por sua ambiguidade, a dobradiça do funcionamento simbólico. É o número singular que cai sob o conceito do excluído, o não idêntico a si mesmo que é incompatível com o verdadeiro; mas também é objeto, e sob seu conceito, "idêntico a zero", cai o número 1 enquanto contagem desse vazio como unidade: "O um agora se concebe porque o zero, como número, é suscetível de tornar-se conceito e objeto" (Miller in Lacan, 1964- 
1965/2006, p. 168). Assim, Frege "resvalou para o equívoco do nome do número zero para instaurar que zero e um são dois" (Lacan, 1972-1973/2003, p. 544).

A sucessão numérica ocorre por conta da ultrapassagem do zero desconforme ao campo da verdade, emergência do traço identificatório de sua unariedade (Miller, 1967). Essa representação de uma falta se repete, a cada vez, na cadeia e define a fórmula do sucessor, $n$ +1 , sucessão metonímica do zero contado como Um. Aí se situa a sutura milleriana, relação circular mas não recíproca entre o sujeito e o significante: "o sujeito é o efeito do significante; o significante é o representante do sujeito" (Miller in Lacan, 1964-1965/2006, p. 172). O +1 da "superfetação" dos números inteiros é correlativo ao sujeito, diluído progressivamente como “possibilidade de um significante a mais” (Miller in Lacan, 1964-1965/2006, p. 169, 170).

Sua divisão enquanto representação de uma ausência é a presença do equívoco matricial do zero fregeano em toda significantização:

O objeto impossível, que o discurso da lógica convoca como o não idêntico a si e rejeita como o negativo
puro, que ele convoca e rejeita para se constituir como o que ele é, que ele convoca e rejeita sem querer
saber dele para nada, chamamos-lhes, nós, na medida em que ele funciona como o excesso operante na
sequência dos números, o sujeito. (Miller, 1967, p. 221)
O próprio traço unário que emerge no campo identificatório da verdade mantém a barreira de rejeição desse objeto impossível, divisão correlata à alienação. Se o idêntico sutura a unariedade do não idêntico a si mesmo como alicerce da verdade, não há metalinguagem nem a possibilidade de escrita de um segundo gozo: "o traço do idêntico representa o não idêntico, donde se deduz a impossibilidade da sua duplicação, e por esse mesmo caminho a estrutura da repetição, como processo de diferenciação do idêntico" (Miller, 1967, p. 221).

Se o inconsciente é estruturado como uma linguagem, trata-se da base do 0 e do 1 que funda a fantasia. É o fato de que a castração implica que algo lhe escapa, mas tal realização é negada pela impossibilidade que varre os ensaios da existência (Lacan, 1971-1972/1997); regime do Um como falta que se reitera a cada desdobramento significante, o real do gozo como índice do Outro sexo. Visado mas falhado por qualquer ser falante, o encontro com a alteridade é tão somente cogitação. 


\subsection{O Zero, a Mulher e o Outro}

Se a pequena diferença é visível desde muito cedo, dispensando a fase fálica para se fazer percebida, como lembra Lacan (1971/2019), por que apenas uma das anatomias ganha substância imaginária através do órgão utensílio da linguagem? Entre o pênis e a vagina, aquele se envelopará na vacuidade suturante da cadeia simbólica e se tornará parâmetro identificatório para o ser falante, que daí não encontrará a proporção sexual, pois a linguagem investe os corpos nos semblantes que forçam a partilha exclusivamente fálica. À determinação fechada no domínio da falta, Lacan prosseguiu o mise-en-scène patriarcal e denominou "homem". O segundo sexo que fica de fora do significado estabelece a frouxidão do argumento na função (Lacan, 1962-1963/2005): “mulher”, dupla por sua inexistência como traço.

Em $O$ saber do psicanalista, além de dizer que a linguagem funciona exclusivamente entre 0 e 1, Lacan (1971-1972/1997) também afirma:

.. . para que haja fundamento do sexo, como se diz, é preciso que eles sejam dois. Zero e Um, isso seguramente faz dois, faz dois no plano simbólico, ou seja, na medida em que nós concordemos que a existência se enraíza no símbolo. É o que define o ser falante.

... esse ser é absolutamente inapreensível. . . . é obrigado, para se suportar, a passar pelo símbolo. É claro que um ser quando chega a não ser [nascer] senão através do símbolo, é justamente esse ser sem ser do qual, apenas pelo fato de falarem, vocês todos participam; mas por outro lado é realmente certo que o que se suporta é a existência, na medida em que existir não é ser, isto é, é depender do outro ${ }^{16}$. Vocês estão exatamente aí, não importa de que lado, a existir, mas para o que é do ser de vocês, não estão tão tranquilos! [itálico nosso] (p. 85)

0 e 1 enquanto 2 no simbólico significa que a inexistência surge a partir do símbolo: o furo se demarca e se nomeia tal como o real, que tem nome enquanto conceito, é efeito do simbólico; a necessidade de discurso funda a inexistência como causa embora a produza pelos “impasses da lógica” (Lacan, 1971-1972/2003, p. 36). Não se trata de duas universais — arranjo onde se suporia rapport —, mas de que em 2 falta 1: "quando fosse preciso que houvesse 2, não há nunca senão um” (Lacan, 1971-1972/2003, p. 118). "Não há 2 que se engendre por meio do 1 e do $0 "$ (p. 120).

Isto é: a dualidade em questão se reduz, na verdade, à paradoxal duplicidade da unariedade simbólica, fundada no equívoco do zero, uma unidade vazia que não pode ser Um, pois é a negatividade mesma da objetivação $(\exists x . \overline{\Phi x}, \overline{\exists x} . \overline{\Phi x})$.

\footnotetext{
${ }^{16}$ Na versão da Staferla consta “Outro” (p. 75).
} 
Zero, simbolicamente, designa tudo aquilo que não pode ser contado imaginariamente e por isso significa o indizível: o próprio conceito de enigma já é uma objetivação. O Um (os significantes que imaginariamente "dão corpo"), por sua vez, conta um objeto concretamente. “Contar” também tem a acepção de incluir, perceber, levar em conta: é a contagem do Um (que dá forma à produção significante positiva) que percebe a realidade visível e engole, como peixe discursivo, sua isca saliente, conforme a metáfora de Lacan em L'étourdit. No mesmo processo, a contagem imaginária do Zero, o apontamento da isca ausente, explicita o que o Um de todo significante é enquanto saco furado, por ilustrar o vazio de seu objeto. Assim, enquanto significante, Zero é digno que deslizar na cadeia como qualquer elemento, mas aqui se trata de que o próprio símbolo está significando sua própria falta; não o zero fregeano, mas a possibilidade de significá-lo.

A inexistência da Mulher que Lacan formula é homóloga portanto à designação da noção de inexistência que o próprio simbólico faz existir.

A unariedade significante, o Um que se descola de cada unidade enquanto extração de sua vacância de conteúdo, é a impossibilidade do simbólico de agarrar suas iscas, pois cada significante se suporta por essa Mesmidade de contradição, o fato de que cada Um é a solidão do "desigual a si mesmo" que corrompe sua própria aglutinação de unidade: esta unicidade faz a unidade mas é desunida em si mesma, incompatível com as exigências lógicas de existência.

O idem de iden-tidade é a mesmidade da pura diferença que faz a força e a fraqueza da significância. A dualidade que toda produção significante implica — positivo-negativo, verdadeiro-falso, presença-ausência - é a própria manifestação da contradição no seio da não contradição; é a mesmidade da diferença recíproca que se atesta como mesmidade da diferença em si mesma, como ruína que paradoxalmente constrói a simbolização. Os pares de oposição que o conceito inventa são a repercussão dessa inconsistência formal. Produção do próprio símbolo refletindo o processo de seu desdobramento, a inexistência como contradição lógica é significada tanto quanto a afirmação de existência supostamente não contraditória.

O dual é portanto o limiar da significação. A Mulher existe tanto quanto o Homem, mas este par, como qualquer outro que rivalize pelo significante, é na verdade a significação do equívoco que cada unidade simbólica suporta em si mesma: o "ter" versus o "não ter" é a própria unicidade da afirmação do traço negada pela impossibilidade de sua inscrição; a binariedade simbólica exibe a própria ambiguidade que cada Um carrega em si mesmo, como existência da inexistência, presença da ausência, insistência da resistência, avanço do recuo, chegada da ida. 
A vagina é muito bem intuível à criança, que a simbolizará segundo a engrenagem unária da linguagem: sua inexistência é parte do mecanismo que cria a existência do pênis (do mesmo modo que um clitóris, grande ou pequeno, pode ser afirmado como fânero, tanto quanto qualquer "pedaço" da experiência humana). A diferença significante (homem/mulher) advém restritivamente da significação fálica, o que implica que "o verdadeiro só existe faltando ao seu parceiro" [itálico nosso] (Lacan, 1971-1972/2003, p. 118).

O significante "mulher", pensado aqui amplamente enquanto instâncias simbólicas do negativo, operaria formalmente como o conjunto vazio que, na teoria dos conjuntos, é manejado por sua nulidade, por ser nomeado enquanto vazio e cair sob a conceituação do Nada (Rona, 2010). O paradoxo aqui é o nome que nomeia que não há nome que o nomeie. Diz-se o que não se pode dizer dizendo mesmo assim.

A possibilidade de instituir este lugar de ausência é intuição que o próprio símbolo cria na pescaria do que julga ser a realidade. Cada "sim" vem acompanhado de seu "não" porque ecoa em sua formação a disparidade que mantém com o que é visto: não há paridade entre palavra e coisa, dualidade que é o fato do Um ser sua própria negação. O conjunto vazio enquanto significante que não vem como secundariedade material é o índice da mesmice nula da busca, pois é a adição de um menos na conjuntização: o que parece dar corpo na contagem desse saco furado ("homem") tem como Outro lado a unicidade dessa vacuidade que não finaliza o processo ("mulher"); antes, o estica. Lembremos que o que se transfere de 0 para 1 é o próprio cancelamento do Um. O que o "masculino", na pena lacaniana, se estrutura pela manutenção de sua unidade, o "feminino" é a oposição interna a ela como esvaziamento de seu Ser suposto, como fato de que o que parece sólido é monotonamente instável, precário, opaco.

O "Dois" é na verdade o conjunto vazio como elemento, permitindo a relatividade dos conjuntos que o têm, e sua única existência de conjunto. A oposição aqui é mera consequência da antinomia entre a unitarização e sua injustificabilidade capital: o Outro em questão, em vez de união ao que já se acredita Um, é a quebra da construção de cada Um, que cada Um já suporta em sua constituição. O Um que cada significante comporta, extraído como a metonímia da vacuidade de cada um, é precisamente o não Um em torno do qual cada Um se afirma, impossibilidade da especularidade na base da identificação.

Sabemos o quanto "mulher" é capaz de se falicizar na cultura. Busca-se aqui demarcar que, quanto a especificar a suposta a alteridade simbólica em relação ao falo - sonho donjuânico do pensamento (Pommier, 1991) —, o registro da feminilidade não exprime Outro 
índice significante e acaba se atestando no imaginário como falta. O conjunto vazio exprime o significante que falta para designar o Outro, na medida em que, ainda no simbólico, viria a nomear essa falta. $\varnothing$ é signo de uma suposição. Ainda estamos no âmbito da existência, mas enquanto esse significante existiria; isto é, o Um se inscreveria no Outro (em vez de apenas cingir sua falta). É o contorno simbólico de uma possibilidade significante, o Outro como lugar vazio que suscita os desdobramentos da fala, como Lacan bem enfatizará, nos seminários 19, nos interstícios de suas escritas quânticas — hiâncias donjuânicas do sujeito.

Se para Frege o "desigual a si mesmo" da ausência de objeto estava subordinado à totalidade de um sistema seguro quanto à subsunção das identidades de objeto aos conceitos logicamente determinados, aqui se trata do próprio fato de que a linguagem só pode operar pela falta e a concomitante presença do símbolo criador de sentido pela extensionalidade de conjuntos locais.

“Zero", "Real", "Morte", "Nada", "Vazio", "Mistério", "Mulher" são significantes como quaisquer outros, mas seriam justamente eles que, por nos darem significação, nos dão significação do inexistente - o que não existe, mas existe enquanto representação de inexistência. Ora, tudo só pode existir pela e na linguagem, inclusive oxímoros como o "círculo quadrado"; o que escapa a esses significantes, ao serem "zerificantes", é a possibilidade de um referencial imaginário fora da lógica fálica do próprio simbólico, que, de Um em Um, dialetiza no conceito o que na forma é dissolução imanente.

Precisamos que não se trata concretamente desses significantes em seu uso cotidiano, mas do que eles representam enquanto instanciações simbólicas do inexistente. Tais significantes não se confundem com a hipoteticidade de um significante Outro que viria dar corpo à ausência ${ }^{17}$, donde se percebe o paradoxo da própria noção de falta. Com efeito, como supor o que falta se esse nome justamente falta? Não seria mais falta se se fizesse presente; ele só pode ser o nome específico da falta porquanto falta.

Empreendimento do ser falante tal como se suporta n’Um dizer. Isto é, se só lidamos com a significação da falta, ao ser que nela não encontra um nome, só lhe resta recair nesse circuito unário de presença-ausência da própria simbolização. Tais significantes, portanto, exprimem a inacessibilidade do Dois porque são o próprio contraponto da gangorra que eleva o 1 como significante que dá narrativa à falta. "Mulher", do ponto de vista das teorias sexuais

\footnotetext{
${ }^{17} \mathrm{O}$ que implica que as instanciações da própria falha do simbólico podem ter qualquer nome.
} 
infantis, e não do ponto de vista cultural enquanto essência da feminilidade. Trata-se desses significantes conforme o lugar de estrutura que sinalizam, e não segundo a mitologia que os circunda.

Assim, a diferença só pode ser tratada a partir do que vem a ser o Um e o Zero na especificação, a partir da linguagem, da sexualidade do ser falante: "não há relação sexual porque a palavra funciona nesse nível em que se encontra . . . especificando o ser falante ... no seu nível, do sexo, o semblante, o semblante de homenzinhos e mulherzinhas" (19711972/1997, p. 35). Um e Zero, dois no simbólico: Mulher existe enquanto significante, mas “é uma palavra cuja referência é faltosa. Ela é, pois, o símbolo da falta. É dessa maneira que ela presentifica o falo e que é o objeto do amor de um homem, tanto quanto do seu próprio" (Pommier, 1991, p. 34). Como Lacan afirmou no seminário 14: “o que ela dá sob a forma do que ela não tem, é também a causa de seu desejo” (Lacan, 1966-1967/2008, p. 237).

Em suma, 0 como significante designa a ausência do segundo sexo na linguagem. A inexistência, enquanto significação fálica que é, paradoxalmente aponta para aquilo que é incompatível ao domínio de sua própria significação. Se o que existe só é existente no e pelo significante, aqui o existente "inexiste", pois não pode ser imaginado senão como nada. O Zero dá o significado da falta em sua pureza, seu estatuto formal de "menos 1". O Um que se pretende preenchido nas significações de presença, por outro lado, denota aquilo que falta empiricamente, contam-se objetos físicos ou abstratos — , mas paradoxalmente contando a própria falta, como vimos na logicização fregeana, isto é, embrulhando a própria ausência de referente na imaginação da identidade.

No caso do 0 , portanto, o referente ausente é significado, tal como o real se designa pelo significante mas não se confunde com ele, isto é, significa-se o insignificável; no caso do 1, o referente ausente é esquecido no imaginário da contagem, donde a sensação de presença de alguma coisa, numa fachada significante qualquer. Enquanto na matemática se trabalha com os números enquanto significantes, esquecendo-se de que não se está contando coisas, a representação de quem diz "eu” se dá às custas de negligenciar que tal essência é sempre Outra. O real comanda o discurso e o sujeito se desvanece na significação: "Donde, divisão do sujeito - quando o sujeito aparece em algum lugar como sentido, em outro lugar ele se manifesta como fading, como desaparecimento" (Lacan, 1964/2008, p. 207). 


\subsection{Yad'lun, pas d'Auvergnats}

O limitado catálogo das pulsões é expressão do impossível que o ser falante promove na tentativa de encontrar proporção no que imagina como essência, acefalismo do Um que se choca com a deformação que o (des)constrói. A teoria dos conjuntos vem em primeiro plano, pois ela tentou “dar conta da função do Um” (Lacan, 1971-1972/1997, p. 102).

Um como conjunto e Um como elemento, Um de diferença e Um de atributo, conjunto e classe: o interesse está no que surgiu ao final da teoria, a saber, a mesmidade desse Um que, enquanto conjunto, se conta como elemento e se constata, por correspondência biunívoca, enquanto falta: "cada número cardinalmente corresponde ao cardinal que o precede, acrescentando-se a ele o conjunto vazio" (Lacan, 1971-1972/1997, p. 103).

Se o Um "só pode partir de sua ambiguidade" (p. 104), o relevo está nesse núcleo do "Real ligado ao Um" (p. 105), donde Lacan conclui que o sexo é real e dual:

Trata-se de saber sobre isso a que retorno porque parecia-me ter aberto a coisa. É a relação de tudo isso que estou reenunciando, que lhes lembro com um breve toque, verdades de experiência, trata-se de saber a função do sexo na psicanálise. A esse respeito, penso, de todo modo, ter atingido as orelhas, mesmo as mais surdas, com o enunciado que merece ser comentado, que não há relação sexual. Seguramente merece ser articulado. Por que é que o psicanalista imagina que o que faz o âmago daquilo a que ele se refere é o sexo? Que o sexo seja real, não tem a menor dúvida. E sua própria estrutura é o dual, o número dois. De todo modo, não há senão dois, os homens, as mulheres, diz-se, e nos obstinamos a acrescentar aí os Auvergnats! É um erro. No âmbito do real, não há Auvergnats ${ }^{18}$. [itálicos nossos] (Lacan, 19711972/1997, pp. 98-99)

Lacan precisa o que vem interrogando: qual a função do sexo para a psicanálise? Onde o discurso analítico se situa, por sua especificidade, no debate transecular da diferença sexual? Por mais que intuitivamente façamos alguma ideia do que vêm a ser os sexos, a questão é remota e nos obriga a abandonar o senso comum de nosso tempo e fazer vacilar nossas concepções no confronto com outras, para com isso nos darmos conta da problemática lógica em jogo, nos alerta Le Gaufey (2015). Se o discurso científico separa, distingue e nomeia duas entidades independentes, o discurso comum é, por sua vez, fortalecido pela suposta garantia que a genética traria no vigésimo terceiro cromossomo como prova da substancialidade de cada sexo assim individualizado (Le Gaufey, 2015).

. . . é preciso liquidar também primeiro o seguinte, que nem mesmo a ideia do indivíduo constitui em nenhum caso o Um. Porque, é visível ao menos, isso poderia estar ao alcance, para o que concerne à

\footnotetext{
${ }^{18}$ Segundo Chassaing (2018), os auvernenses costumam ser considerados uma espécie de "terceiro gênero" no imaginário popular francês: "nem homens, nem mulheres, são auvernenses". Uma conceituação desse tipo vai de encontro a Lacan aqui, que sustenta o duo sexual através da falha lógica do próprio simbólico: "No âmbito do real, não há Auvergnats" (Lacan, 1971-1972/1997, pp. 98-99).
} 
relação sexual sobre a qual, em suma, não pouca gente imagina que se funda, e há tantos indivíduos de um lado quanto do outro, em princípio, pelo menos, no ser que fala, o número de homens e de mulheres salvo exceção, não é? . . . Isso não basta de jeito nenhum para motivar a relação sexual, que eles vão $U m$ por Um. (Lacan, 1971-1972/2003, p. 132)

Não há privilégio algum da psicanálise nessa querela, aponta Le Gaufey (2015). Nosso ponto de vista se insere nos mais variados discursos que, ora pendem para o dualismo essencialista, em que a oposição sexual se fundaria em algo que separaria categoricamente o ser humano, ora admitem uma duplicidade irredutível de qualidades ditas masculinas e femininas que formariam duas extremidades entre as quais haveria as mais variadas possibilidades de mistura.

Freud se viu às voltas com essas duas perspectivas: se a anatomia é o destino e se, no sentido biológico, dimensão tão cara a seu pensamento, óvulo e espermatozoide podem ser, de alguma forma, diferenciados, como então conceber que, no âmbito psicológico e sociológico, como ele nomeava, descobrimos que "a masculinidade e a feminilidade puras permanecem sendo construções teóricas de conteúdo incerto"? Que fazer com "o repúdio da feminilidade", rocha do fim da análise tributária do que, desde os Três ensaios, já havia sido estabelecido, a saber, a libido trata apenas do sexo masculino, donde se formulou que a primazia fálica não diferencia em nada a menina do menino?

Le Gaufey (2015) nota que Freud se situa nesse empenho, embora falho, em ir da relatividade sexual para a concepção de dois sexos individualizados. Análise terminável e interminável marca a avaliação resignada de Freud (1937/1975) quanto a isso: “O repúdio da feminilidade pode ser nada mais do que um fato biológico, uma parte do grande enigma do sexo" (p. 287).

Aqui Lacan retoma o grande enigma do sexo interrogando sua função na psicanálise. A partir do dizer "não há relação sexual”, extraído dessa incógnita que perpassa a obra freudiana, tem-se asseverado que o sexo é real e dual. Não há espaço para os auvernenses, não existem "almas": onde há linguagem, há ambiguidade.

Lacan (1971-1972, p. 93) apoia-se no fato de que "o móbil da teoria dos conjuntos se sustenta inteiramente no fato de que o Um que existe do conjunto é distinto do Um do elemento". As aulas dos dias 19 de abril e 4 de maio de 1972, respectivamente no Panthéon e em Saint-Anne, destinam-se a aprofundar essa ambiguidade segundo a qual qualquer elemento é equivalente ao conjunto vazio, já que este também é considerado um elemento. 
Entre 0 e 1, como vimos, a conjuntização da contradição do primeiro torna-se elemento na extensão do segundo; a equivalência de qualquer conjunto ao conjunto vazio é o fato mesmo de que qualquer conjunto se suporta por essa falta assinalada; cada conjunto porta a mesma indeterminação que o conjunto vazio: a determinação de cada unidade é o mesmo Um como unificação de um buraco (o que se transfere de 0 para 1 ).

Fundamenta Rona (2010):

O que Lacan postula, então, é análogo ao movimento primeiro de instituição do significante como conjunto, na medida em que é por um traço que conta-por-um uma primeira multiplicidade, ainda que seja o mero vazio, nomeando-o como nada. Como um Fiat lux, o axioma do conjunto vazio diz, haja o conjunto vazio, escrito $\varnothing$, a partir de então devidamente nomeado, inscrevendo-o como significante. (p. 103)

Uma vez nomeado em sua unicidade, o vazio pode então ser operável em equivalência a qualquer conjunto, pois o que se assinala é o limite mesmo do simbólico pelo simbólico: “como função de fechamento de um buraco, o nome próprio conjunto vazio sugere, e em seu caso mais que explicitamente, o nível da falta, ou da inconsistência, a maior, suturando-a com e através de seu próprio nome" [itálicos nossos] (Rona, 2010, p. 104).

Nesse sentido, a falta se positiva pelo símbolo que a cinge sem, no entanto, aceder ao simbólico; o que se nomeia é a impossibilidade do Nome, através da demarcação do lugar da falta: é Uma mesma ausência que orienta e sustenta a simbolização, justificando-a com sua presença negativa. Sua reiteração, precisa Cardoso (2010), se dá como insistência pulsional no seio do simbólico, em termos psicanalíticos, reclamando simbolização: "a insistência do Um pulsional é efetivamente a única substância própria e imanente ao registro da linguagem, este valor lógico indeterminado (pois contraditório), é um puro limite significante" (p. 136).

Assinalando a unariedade do traço, $\varnothing$ faz "existir algo organizado a partir do vazio" (Rona, 2010, p. 106): esse conjunto fundador não apresenta o vazio, o que esfacelaria a noção mesma de conjunto, que se constitui por sua consistência, mas representa essa falta, por ser a instanciação de sua ausência. Não seu nome, que é o que dá o sentido da opacidade que cada conjunto carrega (vide discussão do capítulo anterior); o conjunto vazio é a opacidade delimitada, como o zero fregeano envelopado em sua unicidade de absurdo.

Tal nomeação, no entanto, não é mera etiquetação do nada, "é a própria inexistência contada como Uma", isto é, uma "'inércia positiva' no seio do simbólico" (Cardoso, 2010, p. 136, 140). Pode-se portanto afirmar que designar simbolicamente a falta é estabelecer que sua representação se situa no limite do próprio simbólico, descarnando-o com a hipótese de Um 
significante a mais e explicitando que o Um é, fundamentalmente, o "lugar de Uma falta" (Lacan, 1971-1972/1997, p. 103).

Com efeito, o que, no símbolo, poderia espelhar, ainda que falsamente, um vazio? Assim, o $\varnothing$ se faz coerente a designar a alteridade que não se inscreve no simbólico, já que é "Outro com relação a qualquer outro significante"; subjaz a qualquer esforço simbolizador (Rona, 2010, p. 107).

Esse real do qual falo e do qual o discurso analítico é feito para nos lembrar que seu acesso é o simbólico. O dito real, ao qual acedemos no e por esse impossível que somente o simbólico define. (Lacan, 19711972/2003, p. 92)

A equivalência dos elementos na teoria dos conjuntos engendra a unidade, precisa Lacan (1971-1972/1997). O conjunto vazio lhe abre caminhos: "Esse Um, o nada [nade - monade] na medida em que está no princípio do surgimento do Um numérico, do Um do qual é feito o número inteiro, é portanto algo que se coloca como sendo, originalmente, o próprio conjunto vazio" (p. 107).

A mônada em questão é a própria nulidade que sustenta a arquitetura cardinal; não é o ser individual, posto que, a rigor, é esse núcleo de real, isolado, que suscita a fabricação de realidades: "a mônada [monade], portanto, é o Um que se sabe sozinho, ponto-de-real da relação vazia" (Lacan, 1972-1973/2003, p. 547); mas "não mais o chamemos de mônada, porém de Um-dizer" (p. 548).

Lacan correlaciona a cardinalidade do infinito numérico, álefe zero, com o Um da mesmidade $(\varnothing)$, na medida em que é por sua própria falta contável que se pode infinitizar e enumerar os conjuntos, tal como o significante se multiplica e faz "enxame", o que bem designa Yad'lun, segundo Lacan (1972-1973/2010, p. 272) em Encore: “o significante Um não é um significante qualquer, ele é a ordem significante, pois ele se instaura do envolvimento pelo qual toda a cadeia subsiste" (p. 273).

A partir desse momento, a partição do conjunto transfinito chega ao seguinte: se nós igualamos o aleph zero, neste caso, a um, temos, no que concerne à partição do conjunto, o que parece de fato bem concebível, isto é, que a sequência dos números inteiros não é suportada por nada além da reiteração do Um. É por se reproduzir que o Um saído do conjunto vazio constitui o que da última vez dei como estando, no princípio, manifestado no triângulo de Pascal, daquilo que concerne ao cardinal das mônadas, e que por trás dos apoios o que chamei ... o nada [nade-monade], isto é, o um na medida em que sai do conjunto vazio, que ele é a reiteração da falta.

Sublinho precisamente que o Um de que se trata é muito propriamente aquele ao qual a teoria dos conjuntos não substitui como reiteração senão o conjunto vazio, no que a teoria dos conjuntos manifesta a verdadeira natureza do nada [nade]. (Lacan, 1971-1972/1997, p. 106) 
Lacan quer sublinhar que o Um é a reiteração da falta: a reincidência do conjunto vazio nos outros conjuntos é correlata ao que o discurso analítico chama de princípio da repetição. $\mathrm{O}$ valor potencial do significante se infinitiza e deslinda significações somente a partir da diferença relativa que estabelece com outros significantes de um determinado arranjo simbólico, bem na linha saussuriana que Lacan seguiu nos anos 1950. O significante não pode significar a si mesmo; ele só pode ecoar sua unidade de falta: "matematicamente, se aceitarmos que o significante é um conjunto na acepção mais rigorosa da teoria, isto é, composto de conjuntos, o Outro do Outro, seu conjunto totalizante, é inconsistente" (Rona, 2010, p. 88).

Para a teoria do significante, a relatividade simbólica é tributária da mesmidade do Um que, como inércia centrípeta, ponto de impossibilidade atestado através do próprio simbólico, organiza a definição de "homem", "mulher", "auvernense", "lacaniano” etc.: "distinto não quer dizer senão diferença radical, uma vez que nada pode assemelhar-se. Não há espécies. Tudo o que se distingue da mesma maneira é o mesmo elemento. É o que isso quer dizer". (Lacan, 1971-1972/1997, pp. 107-108)

Lacan correlaciona a mesmidade da diferenciabilidade entre os conjuntos com a mesmidade dessa diferença absoluta que se repete, puro balizamento de uma falha. A comparação mútua entre os conjuntos os diferencia, mas entre distinção e definição subjaz a diferença radical no coração de cada um. A diferença possível define-se paradoxalmente pela impossibilidade de Outra comparação que não seja a castrabilidade do próprio sistema.

\begin{abstract}
A teoria psicanalítica vê indicar o Um em dois de seus níveis. O Um é o Um que se repete; ele está no fundamento dessa incidência maior no falar do analisante que ele denuncia com uma certa repetição, em relação a quê? A uma estrutura significante.

O que é, por outro lado, que se produz com o estabelecimento do sujeito no nível do gozo de falar, considerando o esquema que dei do discurso analítico? O que se produz é o que designo no plano dito do mais-de-gozar, é $\mathrm{S}_{1}$, isto é, uma produção significante . . . O que é a mesmidade da diferença? O que quer dizer que coisas que designamos no significante com letras diversas, sejam as mesmas? O que pode querer dizer as mesmas, senão justamente que é único, a partir mesmo da hipótese de onde parte, na teoria dos conjuntos, a função do elemento? (Lacan, 1971-1972/1997, p. 110)
\end{abstract}

Os significantes são os mesmos, a despeito de sua diferença relativa, porque o fundamento da existência simbólica é a mesma inexistência que insiste enquanto real do gozo: "a existência é a insistência"19 [itálico nosso] (Lacan, 1971-1972/2003, p. 160).

Entre a repetição que fundamenta a insistência significante e a produção de $S_{1}$ ao nível do mais-de-gozar, a falação [parlage ${ }^{20}$ do analisando equaciona a existência do amor à

\footnotetext{
${ }^{19}$ Paráfrase de: “o simbólico só sustenta a ex-sistência” (Lacan, 1972-1973/2010, p. 241).

${ }^{20}$ Condensação entre parler (falar) e partage (partição).
} 
inexistência da relação sexual. A mesmidade do rodízio significante das fixações do sujeito equivale a Uma mesma radicalidade da diferença, motor da repetição. Pode-se portanto dizer que o significante-mestre é, em última instância, essa mesmidade do Um que comanda a fala: 'É sempre, seguramente, do significante que eu falo quando falo do Há o um [Yad'l'un]. Para estender esse d'l'un na medida de seu império, uma vez que ele é seguramente o significantemestre, é preciso aproximá-lo, ali onde foi deixado aos seus talentos, para colocá-lo ao pé do muro. (Lacan, 1971-1972/1997, p. 96)

"O significante, como mestre, ou seja, enquanto ele assegura a unidade, a unidade dessa copulação do sujeito com o saber" (Lacan, 1972-1973/2010, p. 273): qualquer composição conjuntista ou significante desemboca em que esse vazio único escreve as infinitas e enumeráveis diferenças relativas possíveis. O Um é isomórfico a qualquer brotação significante: "todas as diferenças que existam, todas as diferenças se equivalem, não há senão uma, é a diferença” (Lacan, 1971-1972/1997, p. 111).

Pela unariedade da linguagem, lógica e sexualidade estão enodadas graças à ambiguidade da palavra "rapport" (Le Gaufey, 2014): sem relação e sem proporção, os parceiros não fazem “o Um” visado pelo Eros freudiano: “Deles [D'eux] não está fundido em Um, nem Um fundado por dois [deux]" (Lacan, 1971-1972/2003, p. 124). A única fusão ou fundação do Um é o equívoco significante, diz Lacan (1971-1972/1997). Os significantes se equivalem em sua nulidade, raiz do equívoco: "a única coisa que interessa do significante são os equívocos que podem sair dele, isto é, algo da ordem do fundir deles um Um, e outras idiotices desse tipo. ... o todos é forçosamente semântico" (p. 130).

A ambiguidade própria do significante busca se fixar no erro do "todos", que se alimenta de atributos e é "uma limitação" (Lacan, 1971/2019, p. 171). Duas universais que, no modelo supostamente animal, nos dão a ilusão de que há dois sexos. O curioso é que, para Lacan (19711972/1997), mesmo ao nível do zigoto não há relação no sentido em que dois formariam um terceiro por sua fusão completa; restam as metades genéticas que não entram na conta da meiose $^{21}$ : "o que é um, novo, faz-se com o que . . cada um deles que largou um certo número de pedaços" (p. 101).

\footnotetext{
${ }^{21}$ Lacan (1971-1972/2003) também diz que a reprodução pela copulação é apenas uma de suas formas; há espécies que a dispensam: em qualquer nível taxonômico, imaginamos existir a bipolaridade sexual, "como se cada ilustração disto que, em cada espécie, constitui o tropismo de um sexo para o outro não fosse tão variável para cada espécie quanto sua constituição corporal" (p. 38).
} 
A necessidade semântica em trabalhar na base do atributo mascara aquilo que da linguagem é falta de fundamento. Até a teoria dos conjuntos, defende Lacan (1971-1972/2003), com a ideia de classe se distribuíam os indivíduos por correspondência biunívoca conforme o atributo comum de cada lado da sex ratio; cada um com sua cada uma. A própria dicotomia clássica do ativo/passivo é posta em xeque no seio de seu enunciado atributivo quando Lacan (1971-1972/2003, p. 179) diz: “o homem, ele é ativo, o queridinho! Na relação sexual, então, parece-me que é mais a mulher quem joga duro!”.

Nesse sentido, na lição do 17 de maio de 1972, distingue-se o Um de diferença do Um do atributo. Este funda o universal qualificativamente; aquele se diferencia da classe, pois se trata, em última instância, do conjunto vazio em sua neutralidade material, contável como elemento nas partes do conjunto e quantitativamente relativizante.

O Um, como diferença pura, é o que distingue a noção do elemento. O Um, pois, como atributo, lhe é distinto.

A diferença entre o $U m$ de diferença e o $U m$ atributo é esta, é que quando vocês se servem de um enunciado atributivo qualquer para definir uma classe, o atributo não virá nesta definição em demasia. (Lacan, 1971-1972/2003, p. 134)

Ao esvaziar-se, a classe deixa de existir; o mesmo não se dá com o conjunto, como vimos, pois persiste o conjunto vazio. Lacan apoia-se na teoria dos conjuntos para reformular inteiramente o estatuto do universal e da existência.

A um sexo corresponde, portanto, a unidade fálica que dá medida ao gozo. Uma exsistência como "a sombra dos conceitos dos quais defende (de bom ou malgrado) as cores", mas não se confunde com eles: o Um de diferença do conjunto vazio que transcende a suposição de atributo dos conjuntos que dá forma, "o que faz exceção ao regime da representação" representando a falha de seu processo; é "o que se pode imaginar de mais pobre: nada se pode dizer dela [dessa exceção], não é permitido senão afirmá-la” (Le Gaufey, 2015, p. 178, 179, 180).

Afirmação do todo, cuja universalidade todavia depende da extração de sua lei de Um de diferença, seu próprio "descompletamento" na infinitização de sua delimitação: ele é um conjunto (Lacan), não uma classe (Aristóteles). Embora ele porte a universalidade do traço, nunca terá todos os elementos. Onde a fantasia fecha a conta do mito é formalmente o ponto de seu desequilíbrio; o que parece ser sua realização está apoiado no que perpetua seu esboço.

Delimitar vem de de- e terminare, que em latim significa rodear, colocar os limites, marcar o término, o fim. A formação dos conjuntos baseia-se na delimitação de onde a unidade 
mesma seria impossível, por ser vazio, falta, falha, desigualdade; o simbólico reflete o oco de sua matéria, que cresce sobre a inexistência. O que ele espelha tão bem no imaginário como corpos obriga o questionamento da insuficiência de sua representação, cuja infinitude é atestada finalmente pela heterogeneidade entre palavra e coisa. O que é identificado é portanto a própria impossibilidade de identificação, e a mesmidade em jogo é a pura repetição desse processo de rodeamento, projeção dos limites da falta, do que "deveria estar lá mas não está".

A bifididade do Um é o obstáculo recíproco a essa suposição de término, enquadramento fantasístico da falha: é o fato de diferença radical que promove diferenças por superfetação de sua incongruência; saco furado sobre saco furado, cujo processo é infinito porque já é prótese da falta, por supô-la delimitável: "a porta de entrada que se designa da falta", "lugar em que se faz um buraco" (Lacan, 1971-1972/2003, p. 108). A ex-sistência do Um que faz a conjuntização, o Um de cada significante, já está de saída corrompida pela negação de seu advento de unidade, repulsa ao que pulsa buscando encontrá-la: uma ex-sistência "intratável por qualquer unidade que seja” (Le Gaufey, 2015, p. 197). A heteridade, portanto, é a desuniversalização que a própria totalização produz por sua inconclusão: o todos é propriamente, como Lacan o diz, uma forçação semântica, pois está formalmente descompletado da resolução que imagina.

O famigerado quadro da sexuação é a esquematização dessa incompletude do sujeito, cuja exceção está articulada à negação de sua instituição de unidade $(\exists x . \overline{\Phi x}, \overline{\exists x} . \overline{\Phi x})$. Ele não encontra outra iden-tidade senão a mesmidade de sua diferença radical no objeto que causa seu desejo, que o indetermina onde ele insiste em se determinar: "É sobre o fundo do indeterminado que surge o que designa e aponta para falar propriamente o il y a [Yad'lun]" (Lacan, 19711972/2003, p. 88).

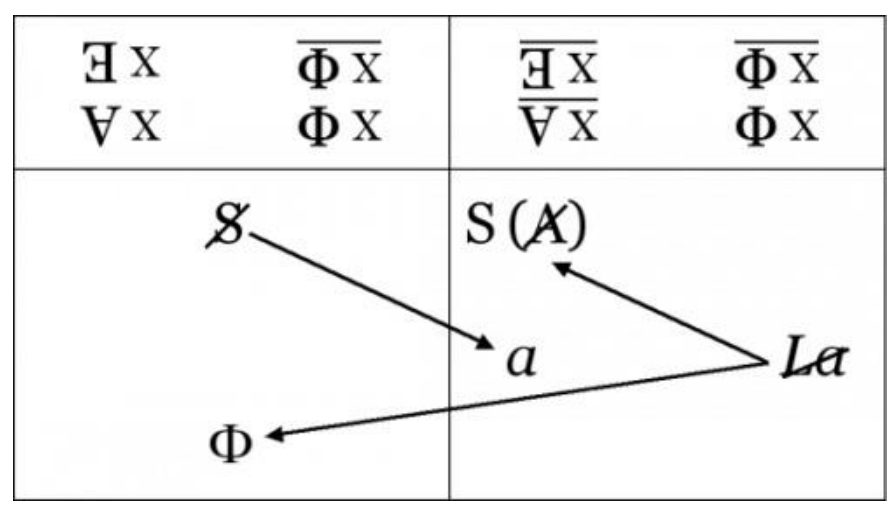




\section{Compacidade e ex-sistência: a implicação dos fracassos}

Encore (1972-1973/2010) é o ápice da preocupação lacaniana com a ontologia. Aqui surge a fórmula "ser sexuado", que só aparecerá, oito vezes, na primeira aula, ressurgindo só mais cinco vezes no seminário em Les non-dupes errent (1973-1974/2016). Ao comentá-la, Lacan (1972-1973/2010) se distingue da "filosofia", generalizada como una, por se considerar em "ruptura" ontológica com suas substancializações predicativas (p. 24). A opacidade do ser "implicado no gozo" exige um tratamento condizente com a hiância do sujeito, "naquilo que causa seu desejo" (p. 24): é na topologia que Lacan irá "costurar", ainda que muito vagamente, seus "fatos de discurso" com os "desvios em impasse" onde o ser se apresenta seccionado de sua suposta pré-discursividade, tal como é lida a elaboração "filosófica" (p. 23, 24).

Repentinamente Lacan (1972-1973/2010) introduz a topologia da compacidade, logo após um comentário sobre o paradoxo de Aquiles e a tartaruga, de Zenão de Eleia. Em vinte minutos de exposição o tema encerra sua aparição na abordagem do gozo: para que serviu? Que interesse teve Lacan nesta observação? Como as propriedades da compacidade podem ampliar o entendimento do rapport impossível, na medida em que ela "converge com uma experiência a tal ponto que isso nos permite articulá-la” (p. 24)?

Concordamos com Darmon (1994): “O formalismo topológico do espaço compacto permite articular as discordâncias do lado homem e do lado mulher como discordâncias não complementares, mas suplementares, e relaciona tudo isso à consequência estrutural dos efeitos de linguagem” (p. 206). A oposição entre fechamento e abertura, que reproduz aquela entre racionalidade e irracionalidade, dá conta de ilustrar a gramaticalidade fraturada que objeta o rapport segundo "a elaboração mais avançada da significância", tal como Lacan (19721973/2010) considera a formalização matemática (p. 187).

Não ignoramos contudo os problemas que o psicanalista enfrenta ao fazer tão intricada "tradução" epistemológica, donde a prudência em falar em "ilustração": no sentido reflexivo em que um saber exprime impasses formais análogos a outro, e não no sentido semântico. O olhar lacaniano é bem distinto da atenção matemática, não só pelos termos e assuntos, mas sobretudo pelo tratamento da imbricação conceitual: conceituar matematicamente pode se revelar bem distante dos interesses da linguisteria, inclusive no próprio questionamento da 
conceituação em si. Discorreremos muito brevemente sobre as aproximações e os distanciamentos possíveis, obviamente significando que aqui não se trata de topologizar a psicanálise nem de psicanalisar sem reservas a topologia. Embora o recurso topológico encontre sustentação a partir do significante (Miller, 1996; Darmon, 2004; Rona, 2010) e a estrutura do sujeito (Eidelsztein, 2006), como procuraremos mostrar, não podemos prontamente tratar a relação entre psicanálise e topologia como evidência (Rona, 2010). Nosso objetivo principal não é a discussão epistemológica.

Precisaremos algumas propriedades dos conjuntos numéricos, seguindo o empenho de Lacan em experimentá-las na abordagem da sexuação; e comentaremos em seguida o paradoxo de Zenão que guiou sua exposição sobre conjuntos compactos. Desembocaremos na interseção das disponibilidades gramaticais do sujeito com a bifacialidade por impasse do ser sexuado. Não o faremos senão ao seguir o caminho de Lacan (1971-1972/2010) na fabricação de seu Um na encruzilhada epistemológica que constituiu $O$ saber do psicanalista e ...ou pior, já então produto de outros avanços formalizadores de seu seminário.

Uma observação nos guiará, de ...ou pior (1971-1972/2003): “o sujeito, na minha 1ógica, exaure-se para se produzir como efeito de significante, bem entendido, mantendo-se tão distinto dele quanto um número real de uma série cuja convergência é assegurada racionalmente" (p. 115).

Como entender esta frase? Destaquemos seus elementos-chave: sujeito, minha lógica, significante, número real, convergência racional. O sujeito é tão distinto do significante quanto um número real frente à racionalidade de uma convergência. Se pudermos conceber minimamente o que isso implica matematicamente, talvez possamos demonstrar em que a compacidade se liga aí.

O número real que escapa à racionalidade é portanto irracional: procuraremos então expor topologicamente como a divisão do sujeito se apresenta como diferença (sexual); o espaço compacto da significância do gozo, a ruptura na qual se enraízam as (im)possibilidades e as (des)continuidades existenciais, foco deste trabalho. 


\subsection{O Um e a razão}

O mundo pitagórico trabalhava os números, medidas de segmentos, na base da geometria. Aquilo que é comensurável se define como racional; a referência à unidade permite ao pensamento encontrar seu espelho representacional na concretude das coisas. Tanto os arithmoi (números inteiros) quanto os logoi (ratio (razão, cálculo) em latim, "relação"; números fracionários) refletiam essas magnitudes unitárias: as frações são meros quocientes de dois números inteiros postos em relação, indicam quantas vezes o divisor cabe no dividendo.

A exclusão do que a isso se declarasse irracional implicava, salvo a dignidade existencial concedida por Platão, sua inexistência. Segundo os gregos antigos, para quem não havia nem numeração decimal, a incomensurabilidade aritmética de medidas todavia determináveis geometricamente era um mistério, comenta Le Gaufey (2014): "Há pois uma espécie de escândalo no fato de que possamos construir geometricamente magnitudes que não se podem medir, enquanto que se se multiplica esse comprimento não mensurável por si mesmo . . . se chega de novo aos arithmoi" [tradução nossa] (p. 18). Algo do racional resiste a se inscrever, isto é, a suposição de racionalidade se mantém como medida da estranheza desses fenômenos.

O exemplo paradigmático é a diagonal do quadrado de lado igual a $1-\sqrt{2}-$, que, a despeito de não poder ser determinada por nenhuma multiplicação de dois arithmoi ou logoi, se formulava pela soma dos quadrados dos lados do triângulo retângulo contido no quadrado em questão, conforme o teorema de Pitágoras: $\sqrt{1^{2}+1^{2}}$. Mais misteriosamente, podia-se evidentemente conceber outro quadrado cujos lados são exatamente essa medida inabordável (por mais logoi que quiséssemos pôr em relação para nos aproximarmos dela):

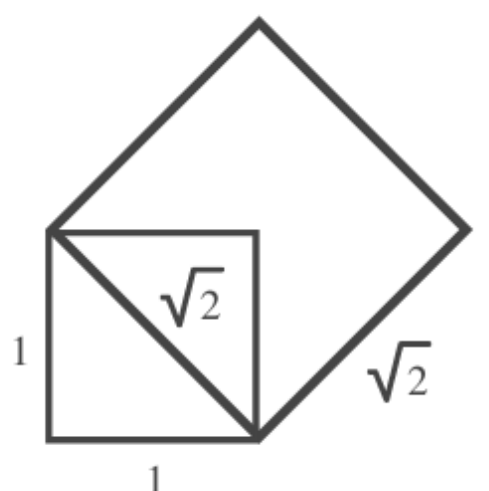


Já se pressentia portanto que os aloga (números irracionais), se se teimasse em se aproximar deles, se articulam à noção de limite, isto é, a convergência de uma sucessão racional cujos termos são cada vez mais parecidos entre si. Foram vários séculos até a noção de limite ser rigorosamente formalizada. Assim, a irracionalidade não é razoável: uma existência inconcebível é um não Um, algo que foge à unidade, não cessa de não se inscrever, numa reticência bem lacaniana, lembra Amster (2015).

No registro do racional, um número no sistema decimal é periódico: a fração geratriz $1 / 3$ resulta na dízima periódica $0,333333 \ldots$; o algarismo 3 repete-se infinitamente, mas se sabe o que é repetido; prevê-se sua completude pela sua periodicidade. Embora "decimal" signifique uma notação que abarca o "menor que a unidade" $-45,6=45+6 / 10(0,6)-$, nos decimais racionais a unidade está sempre presente, pois a base mesma do decimal é o Um. O "menos que Um” está em relação ao Um. Nesse exemplo, 0,6 só pode ser tomado em referência ao 1, que é o todo: cada um dos 10 dígitos do sistema decimal — 0, 1, 2, 3, 4, 5, 6, 7, 8, 9 - representa, em igual proporção, a “distância” que essa parte do número $(45,6)$ está da unidade: $6 / 10$ designa seis pedacinhos de Um todo dividido em dez partes iguais. Assim, no caso das dízimas periódicas há um fim demarcado, ainda que não seja atingido, isto é, conhecemos toda a natureza do número pela repetição do período decimal. É um infinito racional, pois o enésimo algarismo de sua extensão está programado pela finitude de sua determinação.

O que distingue o número irracional não é portanto a infinitude de sua parte decimal, mas o "não cessa" de sua não periodicidade: $\sqrt{2}$ é 1,41421356237...; impossível calcular todos os seus algarismos decimais. Para determiná-los, somos novamente submetidos à jurisprudência do Um, pois é no "um a um” de seu prolongamento que se pode, por exemplo, estabelecer o $100000^{\circ}$ algarismo depois da vírgula. Guardemos esse "um a um" para abordar o "uma a uma" lacaniano mais tarde.

As existências irracionais não podem se universalizar: não são iguais como a fôrma do Um que indistingue os racionais, estão sempre "mais para lá ou mais para cá" em referência à unidade, mas nunca se pode precisar onde. Sua enumerabilidade sempre será parcial, nunca capturará o todo sempre suposto de sua existência. 


\subsection{Aquiles e a tartaruga}

O paradoxo de Aquiles e a tartaruga, postulado na antiguidade grega por Zenão de Eleia, é o exemplo de Lacan (1972-1973/2010) para a incomunicabilidade existencial entre a racionalidade e a irracionalidade: é uma alegoria do rapport impossível que introduz a questão da compacidade, do ponto de vista masculino.

O problema lógico-físico dos corredores é o mesmo de outro paradoxo famoso de Zenão, dito da dicotomia ou do estádio. Para uma dada distância a ser percorrida num tempo finito, é lógico estipular que a metade desse trajeto deva ser completada num tempo igualmente finito: ora, se dessa metade outra metade for determinada, e sucessivamente, podemos seguir dividindo indefinidamente.

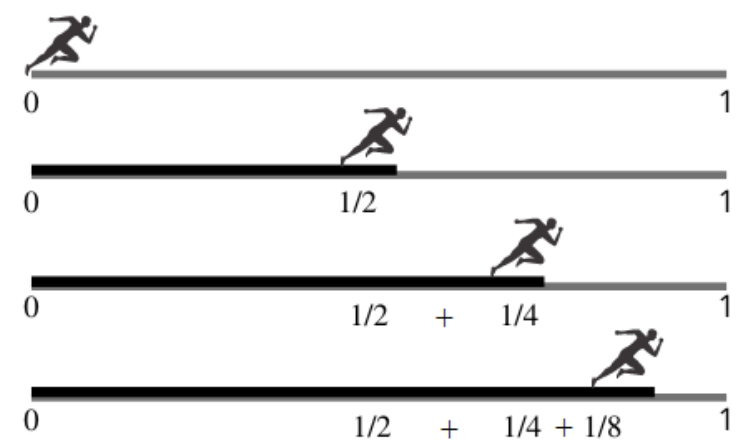

Questão: se dividimos infinitas racionalizações de espaço-tempo, seguiremos em movimento infinito? A soma $\frac{1}{2}+\frac{1}{4}+\frac{1}{8}+\frac{1}{16}+\frac{1}{32}+\cdots=\infty$ faz sentido, haja visto que do lado esquerdo da equação há uma infinidade de unidades? A unidade do todo é considerada em unidades infinitas de subtodos. Como no sistema decimal, mas aqui se divide infinitamente os subtodos em suas respectivas metades.

A indefinição da aproximação racional é signo de seu fracasso: como na dor de cabeça pitagórica diante de uma finitude de segmento cuja medida é infinita, é a virtualidade da abordagem escolhida e não a concretude do ato que faz da precisão uma deriva. Uma infinidade de etapas discretas é obviamente impossível de ser concluída, mas se completa o percurso na realidade: o espaço é infinitamente divisível, como potencialidade, mas não é de fato dividido assim. Essa diferença entre infinitamente divisível e finitamente dividido foi o comentário de Aristóteles ao paradoxo, ao refutar a proposição de infinitude espaciotemporal de Zenão 
(Hobbs, 2017). Em resumo: mesmo passando por finitas etapas discretas para completar seu percurso, o caminhante ultrapassa — mas jamais alcança — um número infinito de pontos.

Se fosse possível ter relação com o infinito, uma proporcionalidade ou equivalência que fizesse do limite a chegada...: a finitude da abordagem do Um não seria necessária se houvesse outra; a falha faz a necessidade, e a necessidade falha. Os paradoxos de Zenão nos ajudam a ilustrar porque só pensamos gozando, como Lacan (1972-1973/2010) diz em Encore. O infinito se ultrapassa, mas não se cumpre: para-doxa do pare-ser lacaniano, sempre defasado do que se efetiva no escrito, por onde só se realiza como semblante. Sua realização só acontece para negar a si mesma, isto é, o impasse de sua presença ultrapassa, mas não agarra, o infinito de sua ausência; sua letra estica sua esquiva e rubrica seu fiasco.

A resposta matemática — não necessariamente satisfatória do ponto de vista lógico ou físico (Hobbs, 2017) - para o paradoxo é que a soma de infinitos finitos tem como resultado uma finitude. Assim, a série $\frac{1}{2}+\frac{1}{4}+\frac{1}{8}+\frac{1}{16}+\frac{1}{32}+\cdots=1$ é convergente, se consideramos por exemplo o seguinte quadrado de lado igual a 1 :

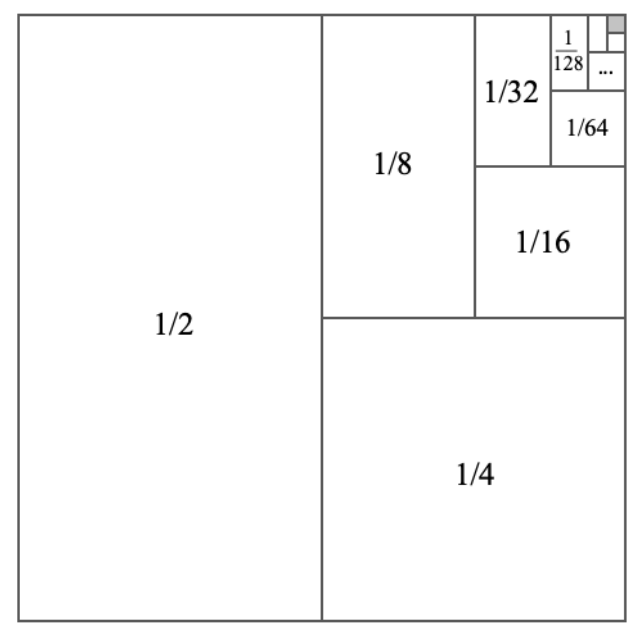

Se não houvesse definição do todo, ou determinação espaciotemporal, a série seria divergente e teria como resultado "infinito". O paradoxo consiste em esticar ad infinitum um espaço e um tempo finitos; no caso, a área finita igual a 1 do quadrado. É o foco argumentativo de Zenão, rebatido com a efetivação finita por Aristóteles.

No paradoxo de Aquiles e a tartaruga, a estrutura se repete. O interesse de Lacan (19721973/2010) provavelmente está no fato de que há dois corredores aqui: ambos estão separados duplamente, isto é, entre si e da chegada; não há paridade, e a unidade do trajeto não se completa para ninguém. A tartaruga e sua lentidão começam a corrida com certa vantagem de Aquiles e 
sua notória rapidez: seguindo o padrão da infinitude das etapas discretas, enquanto ele se esforça para chegar ao ponto de partida dela, esta terá percorrido outro pedaço da corrida e se manterá à frente, a despeito da velocidade do adversário.

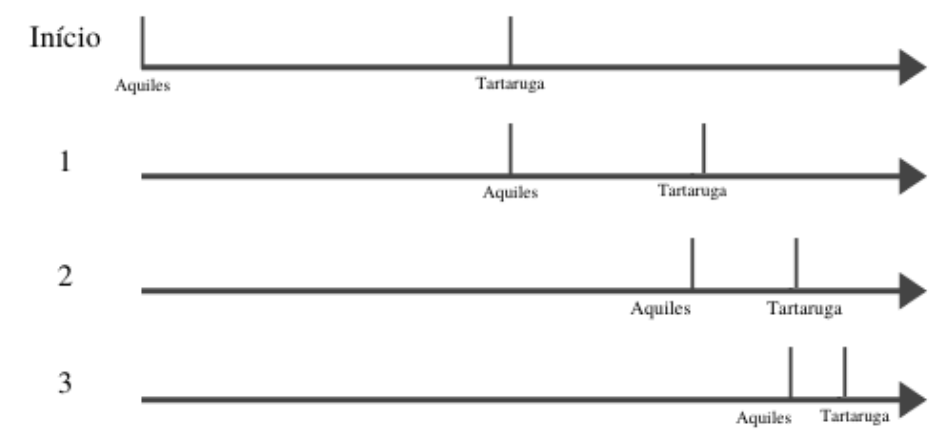

A corrida é pensada não em sua totalidade de espaço e tempo, mas particionada, de pedaço em pedaço, cada Um correspondendo a seu tempo finito de percurso. Se ignorarmos a concretude da diferença de velocidade entre ambos e a totalidade espaciotemporal, a tartaruga terá percorrido, com sua respectiva vantagem, também uma metade. Ambos não alcançam a chegada, porquanto cada pedaço de distância suposto, respectivo a uma finitude de tempo, pode se prolongar infinitamente; infinitos pedaços finitos: o absurdo é o fato de que há um limite, mas sua abordagem é impossível, como se não pudéssemos chegar ao destino de nossa viagem num tempo finito; em outras palavras, o movimento seria impossível.

Na perspectiva de Aquiles, sob a égide da unidade, a tartaruga sempre escapole; sua parcialidade diante do herói é a mesma parcialidade da chegada diante de ambos: parcialidade desabrigada do todo, como o enfoque capcioso de Zenão e, de modo radicalmente diferente, o objeto lacaniano por excelência. Aquiles não alcança a tartaruga nem a chegada; elas, simbolizando a ideia de limite, não alcançam o Um. A convergência racional que subjaz à efetiva vitória de Aquiles é a ultrapassagem factual da tartaruga, dentro da normalidade de espaço-tempo-movimento, em oposição à impossibilidade lógico-matemática de se esgotar uma infinidade de paragens que representam um número irracional.

Assim, a disparidade entre ele e ela e entre ambos e o Um faz do paradoxo "o esquema do gozar", do ponto de vista do homem (Lacan, 1972-1973/2010, p. 19). O Um que Aquiles persegue é o Um do qual a tartaruga escapa; entre ele e a chegada, ela não é nem Um para ele nem atinge o Um da corrida por si mesma. Entre o Um e o Outro ponto, sua indefinição é a que se imiscui entre $\exists x . \overline{\Phi x}$ e $\overline{\exists x} . \overline{\Phi x}$, isto é, entre a unidade e a alteridade. A pulsionalidade de Aquiles, na parcialidade fracassada de Um em Um — por pouco, ela é não toda dele - é o 
gozo do órgão que impede que se goze da suposta totalidade do corpo do Outro: sua fantasia não chega ao Um que lhe completasse $(\exists x . \overline{\Phi x})$; e a tartaruga não chega ao Um que a fizesse toda e Outra $(\overline{\exists x} \cdot \overline{\Phi x})$.

Ambos fracassam, nesse percorrido irracional da alternativa zenoniana, em fazer dos pedaços de um infinito o abrigo de uma unidade que tivesse o estatuto de uma secundariedade; em qualquer ponto do que se enuncie, ambos estão falhando a partir da projeção do Um; o significante do rapport não cessa de não se escrever. A referência é sempre a unidade, por onde a significação ex-siste: "o gozo do Outro, do corpo do outro, não se promove senão na infinitude" (Lacan, 1972-1973/2010, p. 19).

\subsection{Racional, irracional, real}

É o Um visionado como fim, segundo a racionalidade da aproximação, que permite o envelopamento total, mesmo que se trate de um contorno de um vazio; como um salto sobre um buraco, que acompanha seu espaço sem tocá-lo. A cada passo menor que se dá, o limite da chegada está cada vez mais próximo mas incontornavelmente inatingível.

Donde o comentário de Lacan (1972-1973/2010), nessa mesma aula inaugural de Encore, sobre o continuum dos números reais: "Um número tem um limite, e é nessa medida que ele é infinito" (p. 20). Esta é a segunda observação que nos guia nesta exposição da compacidade.

A ideia de limite limita de acordo com a particionamento do pensamento, que só se exprime pela unitarização e seus respectivos derivados: um todo feito de Uns é ele mesmo Um. Sem a medida, como imaginar referentes e abordar certas doses do corpo, construir narrativas para o complexo de castração? Se um número tem um limite, é porque ele precisa ser contido; a unidade de seu saber, ou de saber de sua existência - malgrado seus pedaços sem fim tranquiliza nossa cognição. Nessa perspectiva, conjugar o infinito ao limite corresponde à conjugação paradoxal do impossível ao necessário pela fantasia: as etapas zenonianas caçam essa discrição. 
Desde a tentativa platônica de salvaguardar a existência dos números irracionais, na contramão de seus contemporâneos, mais de dois milênios separaram sua visão ideativa da rigorosidade de Julius W. R. Dedekind, que no final do século XIX promoveu a dignidade existencial dos irracionais sem recorrer à geometria, como na famosa diagonal do quadrado, nem à aproximação exaustiva através dos números racionais (Le Gaufey, 2014). O tratamento da noção de continuidade através do conceito de corte [das Schnitt] sustentava-se aritmeticamente. Permanecia portanto a primazia da racionalidade, pois falar de corte e limite implica uma tentativa de articulação entre o finito e o infinito: "devemos esforçar-nos por dar uma definição completa dos números irracionais utilizando somente os números racionais" (Dedekind, 1872/1999, p. 6).

Assim, como já se suspeitava no mundo grego, entre os números da sucessão dos racionais (inteiros e fracionários) vive uma infinidade de pontos: cada um deles realiza, enquanto limite, uma divisão da reta em duas porções, com o mesmo estatuto que o faria um número racional: "sempre que temos um corte $\left(A_{1}, A_{2}\right)$ produzido por nenhum número racional, criamos um novo número, um número irracional $\alpha$, que consideramos como completamente definido por este corte $\left(A_{1}, A_{2}\right)$; diremos que o número $\alpha$ corresponde a este corte, ou que produz este corte" (Dedekind, 1872/1999, p. 8).

A irracionalidade é portanto o negativo da racionalidade: se o corte não é produzido por um número racional, ele é obra de algum irracional localizado em algum ponto da reta real. Onde quer que se esteja, há um número real. A equivalência topológica e aritmética entre racionais e irracionais significa que agora há relação concebível entre eles, pois todos existem (Le Gaufey, 2014).

Em síntese, o conjunto dos números reais engloba a fantasmagoria dos números irracionais ao conjunto dos números racionais: um conjunto "sem furos" (Amster, 2015, p. 130), completo, é o agregado da insaturabilidade não periódica à racionalidade da contagem.

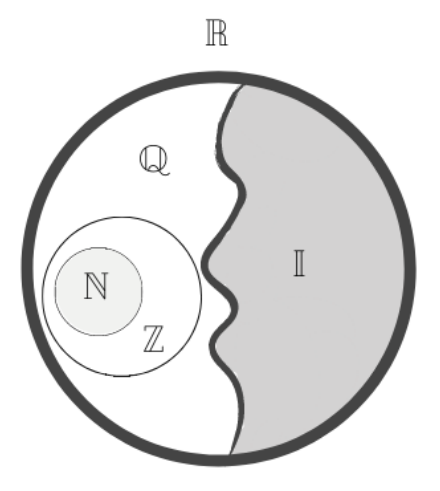


Henri Lebesgue, pedagogo reconhecido em sua época, avançará na crítica dedekindiana: mais decimal que o corte, sua abordagem busca fazer da fatia infinita do número a mensuração da equivalência entre os números reais (Le Gaufey, 2014). Qualquer número da reta tem infinitos algarismos após a vírgula, mesmo os inteiros e sua possível pseudodilatação em zeros: $1,00000 \ldots$ Consideramos e ensinamos os números irracionais desprezando-os; o que foge à comensurabilidade é escamoteado com maior ou menor habilidade através de aproximações: "falamos de valores aproximados que não são próximos de nada" [tradução nossa] (Lebesgue, 1915/1956, p. 18).

Assim, para qualquer número real, a diferenciação não se dará nem pelo infinito nem pela periodicidade de sua decimalidade: naturais, inteiros, fracionários, irracionais e transcendentes gozam de existência a partir da mesma formalização, encerrando a "quase relação de infinita promiscuidade" entre o padrão racional e a correlata desaparição irracional [tradução nossa] (Le Gaufey, 2014, p. 26).

Todavia estamos plantados no campo da exatidão: tanto Dedekind quanto Lebesgue sustentam topologicamente o infinito como fuga à finitude de nossa calculabilidade, mesmo que seja para confessá-lo. Do corte irracional como paragem espectral à decimalidade como idiossincrasia da integralidade, quando tratamos de infinito estamos univocamente tratando de limite (Lebesgue, 1915/1956). Seja como for nossa dignificação existencial da irracionalidade e do infinito, é concebendo seu lugar, por mais turvo que seja, que lhe concedemos operacionalidade; e pouco importa para o cálculo se não podemos determinar sem falhas esse ponto: "Por toda a parte, esses cálculos, ditos exatos, foram destronados pelos cálculos aproximativos e geralmente os cálculos exatos só são considerados porque eles conduzem ao modo mais simples dos cálculos aproximativos" [tradução nossa] (p. 26).

O Um guia a significação e o sonho da petrificação racional a despeito da defasagem do infinito sempre virtual e sempre existente: a densidade do conjunto dos números reais atrai e repele essas propriedades num continuum onde as existências se ligam e se dividem no mesmo golpe. 


\subsection{O problema da compacidade}

A ousadia lacaniana (1972-1973/2010) que se sobressai na aula inaugural de Encore, mais um fruto de sua lógica, é a declaração — sem demonstração decente, sobretudo aos psicanalistas que o seguiam — de que há um "espaço" do gozo sexual, que misteriosamente se revela "compacto".

Conceitos matemáticos de difícil apreensão são lançados prosaicamente: "É nesse espaço, espaço do gozo, tomar algo de limitado, de fechado. É um lugar e falar disso é uma topologia” (p. 20). Espaço, compacto, limitado, fechado...: a antipatia de Sokal e Bricmont (2010) por Lacan os faz considerar que "a oração nada significa do ponto de vista matemático" (p. 33).

Certo, matematicamente a questão do gozo não faz o menor sentido, mas aqui Lacan (1972-1973/2010) psicanalisa a topologia, e não o inverso. Seu uso arbitrário de séculos de esforços em campos estranhos à psicanálise não pode nos despertar prontamente censura nem nos fazer procurar em tudo o que ele diz um álibi. Ele não deve à matemática, e vice-versa. Se aspectos dessas formalizações nos ajudam a construir a ossatura do impasse que especifica o gozo corporal, via do literal em vez do figurado, "pegar algo de limitado e de fechado" talvez não seja uma má ideia. O problema talvez esteja na demonstração dessa pertinência. Sobre isso Lacan é indiscutivelmente e propositalmente deficitário.

Assim, Sokal e Bricmont (2010) têm razão quando dizem que "Lacan não oferece razão alguma que permita pensar que a jouissance possa ser considerada um 'espaço' no sentido técnico desta palavra em topologia" ou quando denunciam que "ele as [palavras matemáticas] mistura arbitrariamente e sem o menor respeito pelo seu significado. Sua 'definição' de compacidade é não somente falsa como também não passa de puro palavreado" (p. 33, 35). Concordamos; mas também pensamos que a psicanálise não perde nada em espelhar o impasse formal de seu sujeito nos paradoxos lógico-matemáticos, para extrair dimensões estruturais que servem a seus projetos éticos. Se existem diferenças radicais, há algo que irremediavelmente aproxima o sujeito, enquanto efeito-falha de significante, e os labirintos da formalização, que igualmente ex-siste pelo dizer da língua que a suporta (Lacan, 1972-1973/2010). Citamos Rona (2010) para concluir que "os limites da formalização nos interessam na medida em que há a suposição de que aí encontraremos o que o próprio movimento de formalização tratou de excluir", ou seja, o que a esses limites se conjuga como infinitude de obstáculo. 
Neste capítulo, escolhemos explorar como a compacidade topológica exprime o impasse formal da representação claudicante do sujeito, ligado ao Um pelo impossível. Para afirmá-lo como o espaço compacto do gozo sexual é necessário introduzir um pouco mais o breve comentário que Lacan (1972-1973/2010) faz nesse 21 de novembro de 1972.

Duas definições são dadas, ditas complementares. Discutiremos o justificável deslize em supô-las assim. O que fica claro contudo é a gramática que subjaz essa relação entre elas; relação com a própria não relação que prescrevem, pois é a heterogenia entre corpo e significante que embasa o comentário: a primeira definição formaliza a perseguição racional do não todo do objeto, como vimos; a segunda é a vertente dessa irracionalidade declinada. Ora, esse casamento é impossível: a partir da disparidade entre Aquiles e a tartaruga, sucessão de falhas na captura do anonimato do Outro, essa hiância que se chama castração e que obstaculiza o rapport se definirá como esse espaço fechado e limitado do gozo.

\footnotetext{
Nada mais compacto do que uma falha, se estiver bem claro que, em algum lugar, está dado que a interseção de tudo o que aí se fecha sendo admitida como existente, num número finito de conjuntos, disso resulta, é uma hipótese, que a interseção existe num número infinito. Isso é a própria definição da compacidade. (Lacan, 1972-1973/2010, pp. 20-21)
}

Como desembrulhar esse problema?

\subsection{Topologia à lacaniana}

Problema no sentido matemático, isto é, decifrar as incógnitas com o que se já se sabe. O que sabemos vem da experiência analítica: decifrar o uso que Lacan (1972-1973/2010) empreende então. Não estamos efetivamente fazendo matemática. As demonstrações e implicações formais teriam outro rigor e outra linguagem, além de servir a outro propósito epistemológico. As questões que fazemos em psicanálise se interessam por pontos às vezes completamente ignorados ou rejeitados pelos matemáticos; sua própria formulação pode chegar a ser uma verdadeira impostura segundo o horizonte de seu raciocínio, e mesmo "contaminar" o rigor próprio de suas demonstrações. Se o formal uniria psicanálise e matemática, a forma necessariamente seria igual? O tratamento da forma é o que difere? A psicanálise seria "não toda matematizável” (Miller, 1996, p. 77)? A topologia seria psicanalisável? 
Que aspectos da topologia da compacidade interessam ao argumento da topologia lacaniana? Quando estava introduzindo a função proposicional para construir suas fórmulas, Lacan (1971-1972/1997) falava de um empréstimo — “o que tomo emprestado oportunamente à inscrição matemática” (p. 80) —, não necessariamente de uma homologia:

É claro que não é porque fiz uso de uma formulação feita da irrupção das matemáticas na lógica que me sirvo dela inteiramente da mesma maneira. E minhas primeiras observações vão consistir em mostrar que, de fato, a maneira como a utilizo é tal que não é de modo algum traduzível em termos de lógica das proposições. (p. 81)

Com a teoria da compacidade Lacan (1972-1972/2010) parece ter feito outro empréstimo oportuno. Seu estilo de exposição não se decide entre um uso da topologia como "fórmula" e como "uma imagem dos fatos" (p. 21, 23), na medida em que ele compara conjuntos compactos e abertos com Aquiles e a tartaruga e o mito de Dom Juan sem o menor "esforço em destacar as relações que estão em causa entre os termos que participam da experiência analítica" (Miller, 1996, p. 77).

Se a citação de Miller (1996), que versa sobre a topologia em geral no ensino lacaniano, aponta o que seria a "topologia de Lacan", para ir contra uma espécie de "fascinação do indizível" que nos deixaria à beira de um misticismo conceitual, mesmo assim não pretendemos aqui salvar o hermetismo de Lacan em prol de uma naturalização de seu emprego da topologia (p. 77). Certo, "não estamos aqui para elucubrar, mas para tentar decifrar Lacan" (p. 73): que essa decifração não se torne caça ao tesouro então, e que assuma a metaforização de seu exercício quando assim proceder. Assim, a topologia da compacidade não pode ser apressadamente considerada evidência se não nos determos minimamente nas razões de sua apropriação. Se "a intuição não nos serve por muitíssimos motivos", não é por meramente refletir estruturas que iremos considerar a topologia "a única via que dispomos para aceder à estrutura real do espaço" [tradução nossa] (Eidelsztein, 2006, p. 22).

A própria ideia de fechado e limitado, oposta à de aberto, exemplifica o malabarismo em manter relativa equivalência entre a estranha demonstração matemática (estranha para nós) e a estranha linguagem de Lacan (estranha também para nós). Quando se inicia certo aprofundamento no assunto, no domínio matemático, de início notamos que o uso psicanalítico dos conceitos faz da complexidade original do campo uma complexidade renovada no corpus lacaniano. "Nada mais compacto do que uma falha": claro exemplo da topologia à lacaniana, onde topologia (“compacto") e psicanálise ("falha") se misturam num novo expediente epistemológico. 
O que sabemos para tratar do problema da compacidade vem da análise. Que o gozo do corpo do Outro não seja signo do amor não é um problema para os matemáticos: que posturas devemos ou podemos assumir ao tratar a formalização que se pode extrair do inconsciente com um pedaço da formalização que podemos extrair, com nossa exterioridade no assunto, da topologia? Não é uma questão exclusiva de mais ou menos expertise, pois interrogamos o propósito mesmo da formalização. Podemos permanecer na alegoria do uso e dizer que tudo pode convir a demonstrar o espaço do gozo, mas nos voltamos para o próprio de cada saber para tentar imprimir um pouco mais de honestidade ao definir o que é cada coisa nessa transposição formal que se faz. Mais transparência que Lacan sem dúvida, que fez da ligeira apresentação do assunto uma espécie de rébus.

\subsection{Preâmbulo da compacidade}

A escola pitagórica não estava pronta para o não Um: o mundo geometrizável que de tudo encontrava uma medida chocou-se, como vimos, com a inapreensibilidade da categoria irracional e a declarou inexistente. O Um é um imperativo cognitivo que por séculos resistiu a conviver com a inexatidão e o infinito que o causam.

Se o sujeito se exaure do contorno significante - primeira frase-guia de nossa exposição - por ser radicalmente diferente dele, é porque é a racionalidade de sua experiência metonímica que cria seu próprio buraco tanto quanto cria o buraco do Outro. O verdadeiro visa o real (Lacan, 1972-1973/2010), mas a verdade só pode se semidizer: há um vão que o significante cria a cada momento em que se articula; só a ideia de infinito pode transmitir o que seria o que sempre fica perdido, e na mesma imaginarização do encore desse fim é o comportamento do Um que prolonga a busca da impossível metáfora do objeto.

Na seriação dos números naturais, os números da contagem no dia a dia $(1,2,3, \ldots)$, o intervalo entre cada Um cria um buraco; não há nada entre eles. Se, como os gregos antigos, nos guiarmos pelo todo de tudo (simplesmente tout em francês), o que não for um número inteiro será quebrado em pedaços (frações, números racionais), integridades que asseguram a concretude geométrica da medição: $\frac{1}{2}, \frac{1}{4}, \frac{1}{8}$... Pode-se quebrar ad infinitum: o problema está nesse não fim; de cada Um que se quebra cada vez mais, vimos que Aquiles não encontrará a 
tartaruga. Que fazer então da interminabilidade da caçada de uma $\sqrt{2}(1,41421356 \ldots)$, de um $\pi$ $(3,14159265 \ldots)$, de um $e(2,71828182 \ldots)$, do número de outro $\varphi(1,61803398 \ldots)$ ? A natureza não é mais tão perfeita porquanto não é mais atomicamente organizável.

Um número real tem um limite no nível de sua infinitude, segunda frase de orientação do capítulo: o limite de um número irracional corresponderia ao ponto em que ele terminaria e onde o próximo ponto da reta começaria, sem intervalo: é um sonho da racionalidade que se desfaz na densidade da reta; a abordagem particionada do infinito de seu comprimento pressupõe a si mesma como etapas de uma totalização, donde a falha ser concebida como tal. O Um não alcança a interminabilidade e a disformidade do não Um, definido aqui como a impossibilidade de integralizar o conhecimento do número. Enquanto ponto, é fechado na reta, mas conceber o começo e o fim da ideia que se faz de um limite é uma antinomia com a própria formalização dos números reais, que não têm brechas entre si; apenas subconjuntos discretos poderiam trabalhar com tal clareza unitária. Entre dois irracionais, imiscuem-se outros irracionais e também racionais; o mesmo vale para os gaps racionais.

O espaço topológico classicamente analisado, através de linguagem geométrica, é esse conjunto "maciço": $\mathbb{R}$ é dito "a reta", "ponto" substitui "número real”, falamos em "distância" entre pontos, "à esquerda ou à direita", intervalo $[a, b]$ como "segmento de reta cujos extremos são os pontos $a$ e $b$ "; a linguagem é mais intuitiva e facilita a compreensão (Lima, 1992).

A própria reta é o número real, o verdadeiro número, diz Lacan (1972-1973/2010) antes de contar o desencontro entre Aquiles e a tartaruga: a abertura, o infinito e a opacidade de sua densidade aproximam o real do conjunto do real lacaniano; a impossibilidade que turva o assentamento numérico já era, como vimos, um impasse pressentido pelos antigos.

Mesmo no âmbito racional a infinitude convive com o remate do número: o 1 pode ser igualmente concebido como $1,000 \ldots$ ou, escandalosamente, como $0,99999 \ldots$. Com mais ou menos rigor é possível provar que $0,99999 .$. não é o maior número do intervalo aberto $(0,1)$. Algebricamente, reproduzimos a demonstração que Amster (2015) realiza com poucas etapas:

$$
\begin{gathered}
x=0,99999 \ldots \\
10 x=9,99999 \ldots \\
10 x-x=9,99999 \ldots-0,99999 \ldots \\
9 x=9 \\
x=1
\end{gathered}
$$


Igualmente: $0,199999 \ldots$ é 0,2 , que fracionadamente dá $\frac{1}{5}$. Assim, no intervalo aberto $(0$, 1), ao nos aproximarmos do 1 - sem alcançá-lo, pois ele está fora do conjunto — , podemos cada vez mais acrescentar noves para esticar a tentativa. 0,999, depois 0,9999, mas também há 0,99999; mas como 0,999999... é igual a 1, que está excluído do intervalo, não existe “o maior” número positivo menor que 1 (Amster, 2015). Na outra ponta embaçada do conjunto, que número positivo poderia ser infinitamente pequeno, isto é, maior que 0 e menor que 0,000...0001? Ou: quanto valeria $\frac{1}{\infty}$ ? E quanto a $\frac{1}{\infty^{2}}$, que seria ainda mais próximo de 0 ? $\mathrm{O}$ infinitésimo, enquanto ponto infinitamente pequeno, também não existe; a notação do infinito indica uma propriedade, um comportamento, um conceito, não um número.

O intervalo aberto $(0,1)$ está entre 0 e 1: começamos vagamente pelo que não é compacidade para, com sorte, torná-la posteriormente compreensível. Sem ser possível definir o menor e o maior número desse intervalo, a infinitude dessa perseguição nos conduz à impossibilidade de contorná-lo. Em outras palavras: qualquer número que se supor nas proximidades dos limites do intervalo estará incluído numa vizinhança de pontos.

Uma digressão para elucidar: imaginemos uma quantidade de leite que se derramou de um copo. O derramamento formará um contorno. Se resolvêssemos tapar esse líquido com pedacinhos de guardanapo, para limpar o chão, uma quantidade finita seria necessária. Não queremos desperdiçar papel, usamos o mínimo para cobrir: para qualquer quantidade primeira de papeizinhos jogados, uma finitude mínima sempre fará a cobertura. Ora, é o que não é possível no nosso intervalo aberto: não podemos estabelecer a quantidade mínima de conjuntos - também abertos, de qualquer cobertura inicial - para subcobri-lo; a finitude aqui é insuficiente. Como Amster (2015) lista:

$$
\begin{gathered}
\mathrm{I}_{1}=(0,0,9) \\
\mathrm{I}_{2}=(0,0,99) \\
\mathrm{I}_{3}=(0,0,999) \\
\mathrm{I}_{4}=(0,0,9999)
\end{gathered}
$$

Recobrir é conter: um conjunto é recoberto por outro quando está contido nele; uma família de conjuntos de recobrimento é a união deles: 


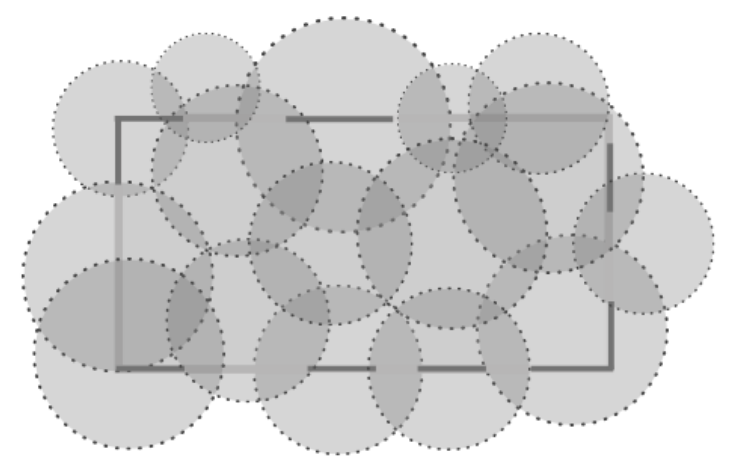

Os discos pontilhados representam conjuntos abertos; o disco maior recoberto pela família tem o contorno contínuo, isto é, é fechado.

Com um pouco de rigor, um conjunto aberto é definido por ser igual ao seu interior, que é o conjunto de todos os pontos interiores de um conjunto. Um ponto interior existe quando num conjunto existe um intervalo aberto. Se um dado conjunto $\mathrm{X}$ tem um intervalo aberto, um ponto $x$ qualquer que esteja nesse intervalo é dito ponto interior; quando todos os pontos interiores são considerados, temos um interior: é o que determina o conjunto aberto. Em outras palavras, todo intervalo aberto, limitado ou não, é um conjunto aberto (Lima, 1992). A definição vaga que Lacan (1972-1973/2010) dá de conjunto aberto e de limite — aquilo "que se define como excluindo seu limite, do que se define como maior do que um ponto, menor do que outro, mas em caso algum igual ao ponto de partida nem ao ponto de chegada, para lhes dar uma imagem rápida” (p. 21) — é portanto incorreta, pois, como definimos, um conjunto aberto não é forçosamente limitado (vide a própria reta).

O conjunto fechado se define por sua igualdade a seu fecho. Preliminarmente, um ponto aderente $a$ a um dado conjunto Y é limite de uma sequência $y_{\mathrm{n}}$ desse conjunto; qualquer ponto que pertença a $\mathrm{Y}$ lhe é aderente, mas pode existir aderência que não pertença ao conjunto. Fecho do conjunto é formado por todos os seus pontos aderentes: se o conjunto é igual a seu fecho, diz-se que o conjunto é fechado. Isto é, todos os pontos de limite pertencem ao conjunto. Em outras palavras, todo intervalo fechado é um conjunto fechado. Outra definição mais simples é o fato de que um conjunto fechado $(F \subset \mathbb{R})$ é complementar de um conjunto aberto $(\mathbb{R}-F)^{22}$ (Lima, 1992).

${ }^{22}$ As demonstrações topológicas também desembocam na definição da própria reta $\mathbb{R}$ e do $\varnothing$ como abertos e fechados simultaneamente. 
Assim, intuitivamente, espaços abertos excluem a ideia de limite em seu interior, embora possam ser limitados; eles não possuem sua fronteira: todo ponto nesse tipo de conjunto "pode se deslocar um pouco pra direita ou pra esquerda sem cair fora do conjunto" (Fajardo, 2017, p. 94). Por outro lado, espaços fechados necessariamente incluem seus próprios limites, que os fecham pela própria limitação. Embora a ideia de "fechado e limitado" possa parecer pleonástica para um leigo, não se trata de sinonímia: a reta real também é um conjunto fechado, isto é, contém todos os seus limites, mas não é limitada; não há uma "parada" ou um "alfinete" nem à esquerda nem à direita. Mesmo o subconjunto $[0,+\infty)$ não é compacto, pois, embora seja fechado, à direita é ilimitado.

A aridez da linguagem matemática talvez se hidrate com a intuição do psicanalista: é a própria completude da reta real que nos permite pensar a compacidade, explica Amster (2015). Com o perdão da imagem, uma coisa sem furos, como um subconjunto fechado e limitado, maciçamente preenchido por sua infinidade de pontos, sempre admite que seja suficiente uma quantidade finita de subconjuntos abertos da reta para recobri-lo. Define-se assim a compacidade, conforme o teorema de Borel-Lesbesgue (ou Heine-Borel).

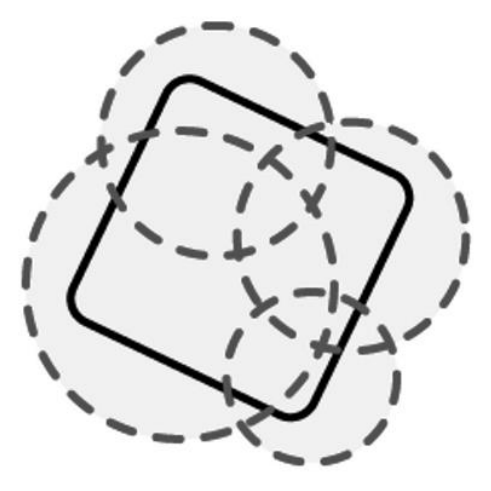

\section{7 "Definições" de Lacan}

Limite, proximidade, continuidade: a topologia trabalha com conjuntos estruturados a partir de funções que definem tais propriedades. Entretanto, "a estrita equivalência de topologia e estrutura”, como Lacan (1972-1973/2010, p. 20) determina a partir de sua demonstração em L'Étourdit (1973/2003), é uma imprecisão, como criticam Sokal e Bricmont (2010): “a topologia é um tipo de estrutura, embora existam muitos outros: estrutura de ordem, estrutura 
de grupo, estrutura de espaço vetorial, estrutura de variedade etc.” (p. 34). Rona (2010) observa que "o uso feito desse ramo da matemática [por psicanalistas que seguem a tese lacaniana] é mais predominantemente metafórico ou alegórico. Isto é, costuma primar pela ausência, pela omissão, ou pelo não desenvolvimento, nos casos em que ele é apontado, daquilo que proveria o fundamento do recurso à topologia” (p. 12).

Como já dito, Lacan (1972-1973/2010) não foi nada generoso nesse 21 de novembro de 1972; não fez questão de explicar, apenas afirmar. A vaga alusão à compacidade não nos parece, contudo, infrutífera, como procuramos mostrar nesta exposição certamente mais detalhada que o usual sobre o assunto. Tudo parece corresponder a alguma coisa bem precisa entre o qualificado "mais recente desenvolvimento dessa topologia" e a impossibilidade da relação sexual, mas a sugerida preciosidade da formalização escolhida resta um enigma (p. 20). Lacan não comentará mais sobre conjuntos compactos no seminário.

Retomando a citação problemática que já lançamos acima: "a própria definição da compacidade" para Lacan (1972-1973/2010) seria uma infinidade de interseções de conjuntos que se fecham numa "falha" (p. 20, 21). O que seria uma falha? Mais adiante: "essa interseção de que eu falo é a que propus, há pouco, como sendo aquilo que cobre o que faz obstáculo à relação sexual suposta"; e finaliza: "Está aí nomeado o ponto que cobre a impossibilidade da relação sexual como tal. O gozo, enquanto sexual, é fálico, isto quer dizer que ele não se refere ao Outro como tal” (p. 21).

Falha, cobrimento de obstáculo, falo: algo se fecha num defeito, numa fenda, num hiato. O gozo fálico só aborda o Outro na infinitude da impossibilidade - conforme Aquiles e a tartaruga - , confessando essa falha como castração. $O$ órgão, que não alcança o corpo, tenta cobrir a fissura em permanente abertura nas bordas pulsionais; pedaços do semelhante suposto Outro. Um fecho e uma abertura: o padrão Um e a indisciplina do Outro correspondem às definições de conjuntos fechados e abertos; Um limite que está naquilo que se fecha e uma abertura que infinitiza o contato com o limite. O masculino para Lacan é um cercamento fracassado; o feminino, a insubordinação ao acabamento. Racional e fechado participam da reparação da falha; irracional e aberto gozam da indefinição.

Mas neste momento estamos psicanalisando a topologia, diga-se. Um, racional, fechado, irracional, aberto e falha resvalam para o interesse em falar da impossibilidade de rapport (sexual). Evidentemente as demonstrações matemáticas descartam os comentários de nosso último parágrafo, pois não estamos provando nada com os meios próprios a sua exatidão formal. 
Racional não é sinônimo de fechado e irracional não é o mesmo que aberto: nem aqui fazemos essa equivalência, enfatizemo-lo, mas as manifestações características do que é racional e do que é fechado se alinham nessa "definição" de Lacan da compacidade; a irracionalidade, forma substantivada que não se vê em livros de topologia, e a abertura implicam um mesmo não Um, outra expressão nada matemática. A formalização nos interessa porquanto indica e corresponde ao que também é formal em nossa epistemologia; há um encontro lógico possível que cuida de não ser falácia.

Assim, a definição que Lacan diz ser da compacidade não o é segundo os matemáticos. A leitura do psicanalista toma aqui a compacidade desses conjuntos que fazem interseção entre si e se satisfaz com o fato de que são compactos, mas o matemático repudiará o estatuto desse comentário como demonstração dessa compacidade. É o teorema de Borel-Lebesgue que demonstrará que um conjunto é compacto na extração de um subrecobrimento finito dele por conjuntos abertos (Lima, 1992).

O que Lacan (1972-1973/2010) apresenta como cobrimento da impossibilidade do rapport, através do gozo fálico, é a propriedade topológica de intervalos encaixantes.

Para Vappereau (in Lacan, 1972-1973/2010), trata-se de uma definição da compacidade em termos de conjuntos fechados. Além da clássica definição em termos de conjuntos abertos, haveria ainda uma definição complementar - diferente da que Lacan propõe - em termos de fechados.

Consideramos os comentários de Darmon (1994) e Amster (2015) mais esclarecedores: o primeiro encontra essa apresentação da compacidade nos trabalhos do grupo Nicolas Bourbaki, e comenta que Lacan (1972-1973/2010) se apoia na complementaridade entre conjuntos fechados e abertos ao dizer que as "definições" são complementares: "Quando Lacan fala do complemento dessa hipótese de compacidade [intervalos encaixantes], ele segue, na verdade, a inflexão do texto matemático [de Bourbaki] que articula, nesse ponto, o recobrimento pelos abertos [teorema de Borel-Lebesgue] como complementos dos fechados” (p. 204). O simbólico, segundo o autor, é um espaço aberto, impossível de ser apreendido como um todo; a linha vertical que corta os lados das fórmulas da sexuação implica que a fronteira se adere à parte fálica, compacta, deixando o Outro lado aberto.

Precisemos o "complementar": embora um conjunto fechado sempre tenha um conjunto aberto que lhe é complementar (Lima, 1992), seguimos a preferência de Darmon (1994) por "suplementar", na linha de uma topologia psicanalítica (p. 204): a cobertura por conjuntos 
abertos como suplemento do fecho fálico traz a radical separação entre a abordagem pelo Um e o espaço do Outro, na medida em que o que o fecho busca e jamais encontra pertence também à abertura que o recobre; o que os separa apesar de seu igual pertencimento ao espaço topológico considerado é a estratégia adotada, isto é, o cercamento pela unitarização versus a indefinição de uma não totalidade. "Suplementar" implica portanto uma outra disposição existencial, uma outra relação com o limite. Complemento é o que está alhures a um conjunto dado, dentro de um universo considerado: o que seria complementar aqui é o excesso do recobrimento aberto da compacidade, um "fora" mas "dentro" desse universo. Falar em suplementação, sob outra perspectiva, considera o comum entre os conjuntos, implicando, na verdade, Outro campo, não interessado, digamos assim, em delimitar-se num projeto de todo; um regime do infinito desenvelopado das coerções do Um.

Amster (2015), por seu turno, explica o encaixe de intervalos como apresentação da noção de limite, na abordagem de um número irracional na reta. O teorema de Borel-Lebesgue é comentado em seguida como a definição propriamente dita da compacidade.

\subsection{Intervalos encaixantes: Yad'lun, encore}

Se axiomaticamente qualquer segmento era mensurável para os gregos antigos, como precisar aritmeticamente qualquer projeção geométrica facilmente desenhável sobre uma reta?

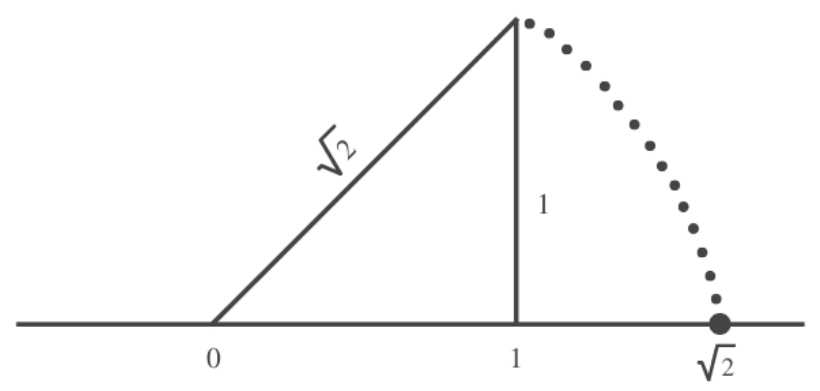

Que número ao quadrado seria 2? Ele necessariamente deveria ser igual ao lado de um quadrado de área 2. Como vimos, Aquiles e a tartaruga vivem sob a projeção de uma chegada que jamais se realiza: um pretendido Um total demorado em Uns infinitos. Há uma convergência que não se realiza nessa abordagem, refutável pelo fato de que ela efetivamente 
se realiza: pelo hiato criado entre a partida e a chegada, que não toca essa infinitização racional, o Um total é o vivido em oposição ao vivível dos pedaços perseguíveis e demoráveis. Ou seria o contrário? Aquiles ultrapassa a tartaruga, nunca a alcança a não ser no infinito: defasagem entre "passar por cima", como se diz no popular, e atingir, deter(-se); em inglês, algo como over em vez de $o n^{23}$. Como no paradoxo da dicotomia, de Um em Um o perseguidor captura não todo o trajeto ad infinitum. Há uma rebeldia do limite que gera uma abertura a cada fechamento sonhado. O "todo" está radicalmente separado de suas "partes", fatalmente lhes ex-siste. $\sqrt{2}$ é um número entre 1 e 2 , mas onde exatamente? Um ponto lhe é garantido, mas ele pode ser totalmente conhecido?

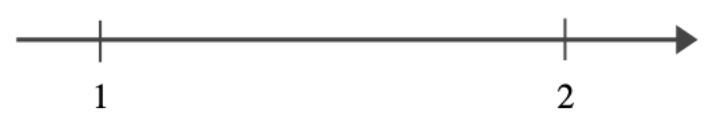

Sabe-se geometricamente sua localização: em algum ponto entre [1, 2]. Reduzindo o intervalo fechado, pelo sistema decimal o segmento unitário pode ser dividido em 10 pedaços iguais:

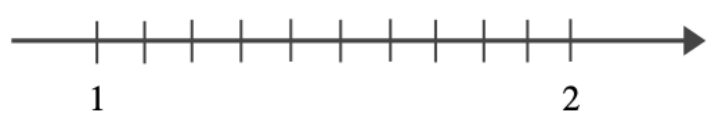

O Um entre 1 e 2, dividido em 10 Uns, pode agora ser dividido em novos 10 Uns entre 1,4 e 1,5:

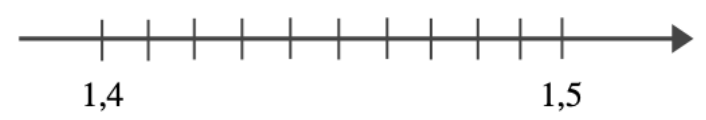

Um novo zoom pode ser criado entre 1,41 e 1,42 com 10 outros Uns:

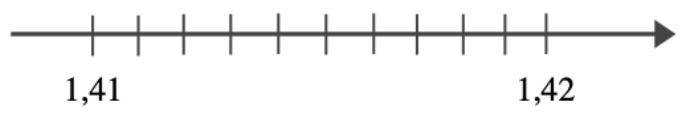

Recapitulando: o segmento unitário é dividido em 10 partes; então $\frac{1}{10}$ dele é dividido em 10 novas partes; depois pegamos $\frac{1}{10}$ de $\frac{1}{10}$ do unitário, isto é, $\frac{1}{100}$ do unitário; em seguida, $\frac{1}{1000}$ do unitário, indefinidamente. Prolongamos as casas decimais que visam assimilar os pedaços do Um suposto. Os intervalos afunilam-se:

${ }^{23}$ Over: acima, sem tocar o objeto referido; on: algo está sobre, toca o objeto. 


$$
\begin{gathered}
\mathrm{I}_{1}=[1 ; 2] \\
\mathrm{I}_{2}=[1,4 ; 1,5] \\
\mathrm{I}_{3}=[1,41 ; 1,42] \\
\mathrm{I}_{4}=[1,414 ; 1,415]
\end{gathered}
$$

Cada intervalo novo está contido no anterior. A tendência geométrica do estreitamento é zerar a distância entre os pontos considerados, isto é, há um único elemento suposto estar contido ao mesmo tempo em todos os intervalos, que corresponderia ao tamanho do segmento $\sqrt{2}$. Este ponto comum é a interseção não vazia da infinita aproximação:

$$
\bigcap_{n=1}^{\infty} I_{n}=\{\sqrt{2}\}
$$

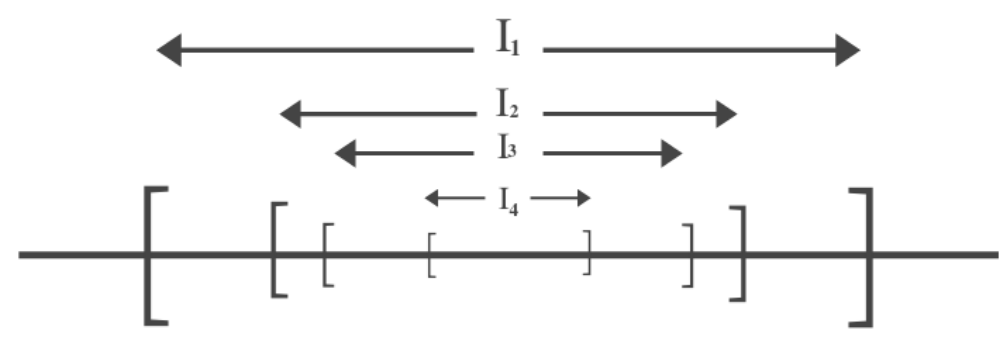

A propriedade dos intervalos encaixantes se satisfaz com a completude da reta real (Fajardo, 2017). Somamos as "completudes parciais" $(0,4+0,01+0,004 \ldots)$ à unidade para tentar apreender a totalidade dessa medida que sempre foge a nosso mecanismo racionalmente orientado. Se estivéssemos lidando com um conjunto exclusivamente racional, a propriedade de encaixe não se sustentaria. Há buracos entre os números racionais, criados pelo Um: sempre representáveis em frações a partir de números inteiros, sua enumerabilidade — em correspondência Um a Um (bijeção) com os números naturais, os infinitos da contagem implica uma infinidade menor que a infinidade impossível de listar dos números irracionais.

Pelo argumento da diagonalização de Cantor, provou-se que o campo do irracional admite combinações decimais que escapam à determinação do Um da contagem. Há uma listagem possível para todas as frações, mesmo que passemos a vida nessa empreitada, mas o irracional é bem aquilo que essencialmente resiste ao tratamento pela completude.

Matizes infinitas abundam o próprio infinito: no final de Encore, Lacan (19721973/2010) compara a parcialidade gozosa que sustenta o semblante de alma, base do rapport 
suposto, com o espectro da luz branca. A ilusão de totalidade se contradiz na ausência do branco naquilo que ele produz. O degradê infinito suporta-se nessa causa faltosa: "o gozo de que se trata está fora do campo desse espectro" (p. 232). Poderíamos acrescentar que, na percepção das cores de um modo geral, é nossa interpretação que conta: branco, preto e rosa, por exemplo, ex-sistem enquanto purezas de comprimento de onda. Mas o universo das cores se imagina, tal como a integralidade de um segmento irracional. Embora lidemos com quebras infinitas segundo Uns que encolhem cada vez mais para precisar as bordas desses números, esses limites sempre nos são não todos, como a tartaruga da caçada de Aquiles.

Em ...ou pior (1971-1972/2003) extrai-se mais uma vez no ensino lacaniano que o pensamento trabalha na base do Um e o irracional é o que lhe escapa. Mesma incomensurabilidade entre o irracional número de ouro $(\varphi)$ e as possibilidades de divisão em média e extrema razão desde Euclides.

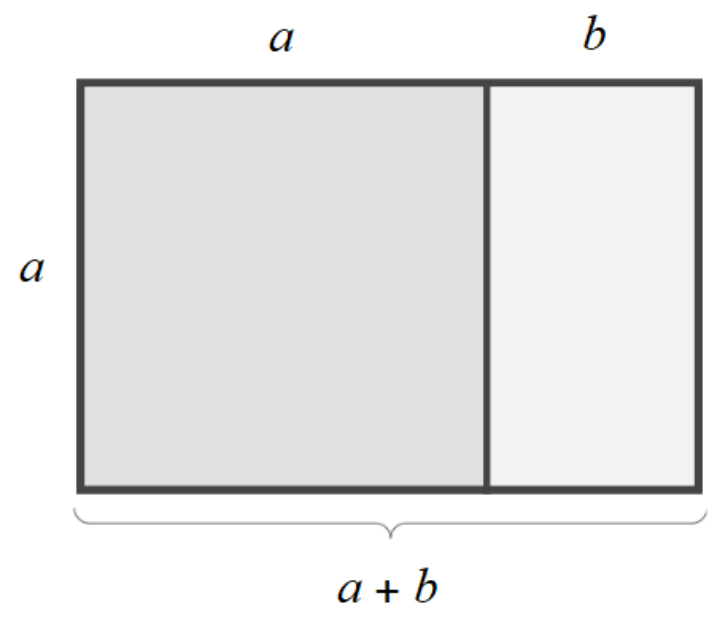

$\varphi$ é a razão entre o maior e o menor dos subsegmentos $\left(\frac{a}{b}\right)$, mesma proporção entre o segmento do retângulo maior $(a+b)$ e o lado do quadrado $(a)$ :

$$
\varphi=\frac{a}{b}=\frac{a+b}{a}
$$

Sabemos que:

$$
\varphi=\frac{a+b}{a}=\frac{a}{a}+\frac{b}{a}=1+\frac{1}{\varphi}
$$

A igualdade entre $\varphi$ e $1+\frac{1}{\varphi}$, dentre outras propriedades, faz dessa misteriosa entidade o mais irracional dos números. Sem relação com a unidade mas frequentemente articulável a ela, desdobra-se num curioso e infinito fracionamento: 


$$
\varphi=1+\frac{1}{\varphi} \rightarrow \varphi=1+\frac{1}{1+\frac{1}{1+\frac{1}{1+\cdots}}}=1,61803398 \ldots
$$

Essa foi a escolha de Lacan (1966-1967/2008) para metaforizar a evasão do objeto $a$ em (não) relação ao significante a partir da sequência de Fibonacci, em A lógica da fantasia. A sequência se dá pela somação dos dois termos anteriores, começando com duas unidades: 1, 1, $2,3,5,8,13,21,34,55,89,144,233,377,610 \ldots$ A divisão de cada termo pelo anterior aproxima-se cada vez mais da razão áurea euclidiana:

$$
\frac{1}{1}=1 ; \frac{2}{1}=2 ; \frac{3}{2}=1,5 ; \ldots \frac{233}{144}=1,6180556 \ldots ; \frac{377}{233}=1,6180257 \ldots
$$

Em De um Outro ao outro, a divisão do sujeito pela distinção radical a uma orientação racional, como em nossa frase de ...ou pior, é retomada por essa propriedade da sequência de Fibonacci: "Esse pequeno $a$ irracional . . . se estabiliza como razão [rapport], na medida do que se engendra da representação do sujeito por um significante numérico diante de outro significante numérico" [tradução nossa] (Lacan, 1968-1969, p. 186). O alongamento significante cinge cada vez mais o que irremediavelmente lhe escapa (Le Gaufey, 2015); a detumescência do órgão apenas mascara a inacessibilidade de sua excepcionalidade.

Sem medida é o que faz falta à racionalidade, e somente a ela: tanto no encaixamento por intervalos fechados como nas peripécias de $\varphi$ na "natureza", olhado do Um que se esforça em mensurá-lo, o irracional só pode ser, por exclusão, a indisciplina do não $a$-bordável. Na falta da determinação, via que o sujeito dispõe para $a$-bordar a sexualidade (Lacan, 1964/2008), costuma-se colocar uma letra para representar um número irracional, o número impossível de escrever: impossibilidade coberta pelo fecho dessa literalidade que confessa sua castração.

Topologicamente, não há falta na reta real porque o embaçado irracional suprime brechas. Onde o que se fecha na falha não encontra a escrita do todo de sua reparação, ele se abre, alhures, na continuidade rebelde à fronteira. A infinita caminhada discreta crê capturar e integrar pedaços do continuum da reta, impossível de ser traduzido e organizado em Uns, numa frase que se quer inteligível. O que faz o significante ter valor de significação é sua própria discriminação face a outro significante, que lhe confere essa existência potencial, nunca idêntica por si mesma, mas tão somente fruto da oposição; diferença que exprime a autodiferença radical da unidade mesma, como precisa Darmon (1994): "É a característica totalmente estranha e paradoxal do significante apresentar manifestamente unidades, mas essas unidades são 
impossíveis de se apresentar como tais" (p. 163). É disso que se trata na não relação entre a aproximação fechada, que produz centelhas de verdade, e a abertura indiscriminada que a contém e a excede.

A função essencial da linguagem é portanto "preencher tudo que deixa aberto que não possa haver relação sexual" [itálicos nossos] (Lacan, 1971-1972/2003, p. 25). Irracional é o que não é racional; a abertura de um infinito é o que vaza de uma limitação e faz do fracasso do finito o encore da castração. Nas bordas do corpo, a abertura se enumera, pois é finita, pela própria compacidade do falicismo que cria furos segundo sua cognoscibilidade unária. $\mathrm{O}$ falo compactante se pretende finitizante: o ponto caçado fechar-se-ia enfim na falha instaurada por essa abertura que irrompe do Outro, o irracionável, o ilógico, o inconcludente; o percorrido do número visa defini-lo. Topologicamente, o que se fecha na aproximação (em vez de falha, prerrogativa da psicanálise) não é vazio pela densidade da reta, que garante um lugar no infinito de seu interior; mesmo assim, esse ponto nunca poderia ser completado, mas tão somente suposto, atividades da razão. Demonstrável mas indeterminável, nunca dará as caras.

Tudo o que se fecha a partir do Um é o que se imagina a partir da falta desse Um $(\exists x . \overline{\Phi x})$. Aqui o não vazio, psicanaliticamente, é inquilino do vazio, suposição de um lugar a ser preenchido. A aproximação infinita do corpo do Outro se pauta portanto por uma vacância: só em sua completa ausência, enquanto possibilidade de conclusão pela unidade, ela pode saturar a diametralidade da presença suposta a ser completada. No aberto desses furos na abordagem do parceiro, a indefinição correlata (não) interessa à fixação da fantasia; à falta real se sobrepõe a falta simbólica (Lacan, 1964/2008). O sujeito se exaure a cada aproximação racional que tenta convergir no Um da relação, pois o não todo do objeto $(\overline{\exists x} . \overline{\Phi x})$, que parece mais áureo a cada passo, faz a divergência matemática desse processo.

\subsection{Teorema de Borel-Lebesgue: uma a uma}

É no brilho desse pare-ser que Lacan (1972-1973/2010) situa a encarnação do Outro como ser sexuado. O impasse da ex-sistência irracional implica a sucessão de insucessos e a enumerabilidade que a acompanha, ex-sistindo como Um a mais $\left(\mathrm{I}_{\mathrm{n}}, \mathrm{n} \in \mathbb{N}\right)$ : a compacidade 
comprime o impossível na necessidade e produz falhas consecutivas, listáveis contudo na contingencialidade de cada fiasco; cada fecho coincide com uma abertura alhures, garantia da reta como suplemento; à infinitude de encaixes corresponde uma finitude de abertura. O Um e o Outro se articulam topologicamente apesar de sua heterogenia e sua incomensurabilidade.

A definição de conjuntos compactos pelos conjuntos abertos suplementa portanto a propriedade do encaixe de intervalos. Em Lacan (1972-1973/2010), ao contrário, essa propriedade é dada como definição e a definição propriamente dita vem como complemento da hipótese de compacidade: "supondo-se esse mesmo espaço delimitado, fechado, recoberto de conjuntos abertos . . . é equivalente dizer, isso se demonstra, que o conjunto desses espaços abertos se oferece sempre a um sub-recobrimento de espaços abertos, todos eles constituindo uma finitude" (p. 22). Lacan não demonstra nem nomeia a complexidade desse enunciado como teorema de Borel-Lebesgue (Heine-Borel).

A compacidade costuma ser demonstrada pelo fato de que um conjunto fechado e limitado admite uma subcobertura finita para qualquer cobertura por conjuntos abertos. Em outros termos, um conjunto é compacto sempre que, para qualquer cobertura por conjuntos abertos, uma quantidade finita desses conjuntos já é suficiente para cobri-lo, isto é, "precisamos mostrar que todo recobrimento aberto admite sub-recobrimento finito" (Fajardo, 2017, p. 98). Finalmente, um conjunto compacto sempre poderá estar contido numa união finita de conjuntos abertos.

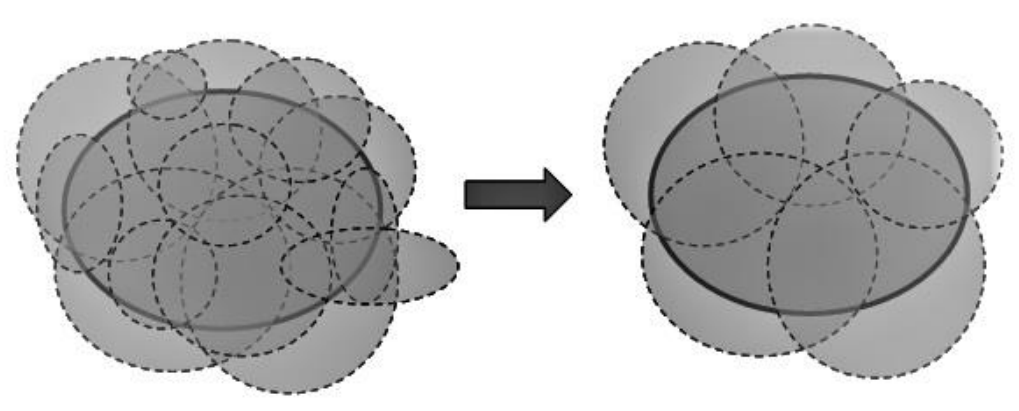

Como Amster (2015) faz notar, a cobertura por conjuntos abertos, mesmo em quantidade finita, implica um excesso necessário para conter a fronteira do espaço compacto, com exceção do conjunto vazio. Conforme o exemplo que Lima (1992, p. 142) dá a respeito dessa retirada de excessos (quantidade de conjuntos abertos) que mantém todavia essa ultrapassagem mínima inevitável (subcobertura): os intervalos $C_{1}=(0,2 / 3), C_{2}=(1 / 3,1)$ e $C_{3}$ $=(1 / 2,9 / 10)$ formam uma cobertura por abertos $C=\left(C_{1}, C_{2}, C_{3}\right)$ do intervalo fechado e limitado 
$[1 / 4,3 / 4]$. Isto é, $[1 / 4,3 / 4] \subset C_{1} \cup C_{2} \cup C_{3}=(0,1)$. Mas a subfamília $C^{\prime}=\left(C_{1}, C_{3}\right)$ já basta para subcobrir o intervalo, pois $[1 / 4,3 / 4] \subset C_{1} \cup C_{3}=(0,9 / 10)$. Cada elemento do conjunto compacto está contido em ao menos um membro da subfamília de abertos.

Aquiles e a tartaruga, número real e limite, conjuntos compactos: a sequência desse início espesso de seminário formaliza com a topologia o que é uma exigência lógica do funcionamento da linguagem. Em bom lacanês: não há relação sexual. Por Um lado, há a totalização, o fecho, o sentido; por Outro lado, há a indeterminação, o aberto, a fratura. Existência e exigência andam juntas: o irracional impõe infinitude ao racional e o anonimato que acompanha a repetição que faz o gozo dá a substância de seu falicismo; a falha onde o fechamento busca conter a significação é a inconsciência da abertura que o excede.

Exigência do Um, exigência da infinitude: a ex-sistência paradoxalmente liga os caminhos heterogêneos do ser sexuado a despeito do impossível que os separa. Como entender isso com a subcobertura finita do espaço compacto do gozo sexual?

Acompanhemos os lampejos da fala de Lacan (1972-1972/2010): ele diz que o que se refere ao gozo, à sexualidade, é marcado pelo buraco do Outro, só alcançável na infinitude, o que implica a necessária via do falo, isto é, da falta. Não há Outro, Yad'lun: a aproximação unária projeta-se com sua universalidade e é descompletada, suplantada pela alteridade que se abre com sua inacessibilidade; o encaixe compacto lhe dá Um lugar mas é excedido pelo infinito de sua inadequação, reenviada contudo à limitação do fecho fálico. Pela própria demonstração da compacidade, a abertura é articulada ao fechamento, e vice-versa. Não há rapport possível, mas há implicação. Lacan questiona, como fará ao longo do seminário: “Será que do Outro lado algo não poderia ser alcançado que nos dissesse como seria realizado aquilo que até aqui não passa de falha, de hiância no gozo?” (p. 20).

Enigma do pensamento que será arquitetado na inscrição sexuada do dia 13 de março de 1973, ampliação das já decantadas fórmulas quânticas.

\begin{tabular}{|c|c|c|c|}
\hline $\begin{array}{l}\text { G } x \\
\forall x\end{array}$ & $\begin{array}{l}\overline{\Phi \mathrm{X}} \\
\Phi \mathrm{X}\end{array}$ & $\frac{\overline{G X}}{\overline{F X}}$ & $\begin{array}{l}\overline{\Phi \mathrm{X}} \\
\Phi \mathrm{X}\end{array}$ \\
\hline & & $S(X)$ & \\
\hline
\end{tabular}


Do lado esquerdo, o Um, do direito, o Outro, separados pela castração que os corta verticalmente (Darmon, 1994). Se o simbólico fosse dividido simetricamente, a fusão estaria garantida pela totalidade e pela visibilidade de seu conteúdo; o que faltasse de um lado estaria no outro; mas a falha do Outro é a própria abertura simbólica, o fato de seu inesgotamento nas vizinhanças dos limites, a despeito dos fechos identitários que visam captar a inacessibilidade do corpo. Sempre falta um pouco mais, que não passa pelo que se tenta apreender do sexual. Assim, no esquema da sexuação, o que o lado de $\Phi$ busca compactar do lado de $\mathrm{S}(\AA)$ é uma fragmentação desse espaço que não encontra o limite. Cada pedaço enumerado de uma infinitude irracional, embora traga consigo a listagem possível das aberturas que encontrou no Outro, é Um mesmo fracasso que universaliza a masturbação do reino da falta; um Um a mais que não é Outro, um Outro a menos: o Outro é a castração do Um, o que fica de fora de sua compacidade e não sabe o que é isso, $\mathrm{S}_{1} \diamond \mathrm{S}_{2}$.

Limitação, fechamento, compressão: a ideia prosaica de compactar admite certa coerência topológica. A compactação de um conjunto de fato o torna "menor", isto é, $[0,1]$ é "menor" que $(0,1)$ (Lamb, 2017). Embora o intervalo aberto seja maior que o fechado, como explicar que um conjunto menor contenha um conjunto maior, $(0,1) \subset[0,1]$ ? Um conjunto que se comprime pela adição de elementos e se expande com a retirada desses mesmos pontos, 0 e 1 no caso. Se no intervalo aberto, como já vimos, jamais se encontra o menor e o maior de seus elementos, ficamos sempre no Um a Um se sua delimitação infinita; no intervalo fechado o menor e o maior existem, são as extremidades aderentes e pertencentes ao conjunto. As duas modalidades de conjunto comportam infinitos pontos, mas o conjunto aberto tem mais, pois prolonga-se indefinidamente sem tocar nos limites. É um não todo no sentido lacaniano da expressão, isto é, não é um alguns órfão de um alguns outros que o concluiria; é literalmente uma não totalidade. Já o conjunto fechado, por outro lado, é um todo, com “começo e fim”".

A compacidade constrange a indefinição do campo aberto que a recobre; é o que se vê na finitude da coleção que a contém (Lamb, 2017). Não igualmente, há uma imposição da abertura que implica a universalidade do Um. Como Lacan (1972-1973/2010) enfatiza, “aí que é estranho, que é fascinante ... essa exigência do Um . . . é do Outro que ela sai: ali onde está o ser está a exigência da infinitude" (p. 23). Por outro lado, "o homem crê criar . . cria, cria, cria a mulher!” (p. 257). Se o mais-de-gozar da mulher como Outro suscita sua criação fálica pelo homem, ele também "a põe a trabalhar, mas ao trabalho do Um" (p. 258). Por isso o Outro é barrado pelo Um-a-menos. 
Contata-se dessa diferença, a diferença sexual, que o Um se sustenta, se conta "sem ser" (p. 258). Há uma continuidade entre fechado e aberto que paradoxalmente os desconecta: que se feche, se abre. Se a compactação é menor que a abertura, poderíamos psicanaliticamente ler aí uma perda: o que não entra na estratégia do fecho se prolonga e se descompleta na abertura que o recobre, causando e negando o encore da cisma. Cada passo aquiliano, cada conquista donjuânica enfrentarão uma nova perda, que traz a aparência (adição de pontos) de ganho.

Lacan (1972-1973/2010) precisa: “O que se escreve, em suma, o que isso seria? As condições do gozo. E o que se conta, o que isso seria? Os resíduos do gozo!” (p. 257). O maisde-gozo da heteridade da mulher como ser sexuado associa-se com o mais-de-gozar que essa posição oferece no encontro. O que o homem perde no gozar é ao mesmo tempo o que o condiciona na necessidade de seguir esses rastros: “esse $a, a$-sexuado, não será por conjugá-lo com o que ela tem de mais-de-gozar sendo Outro, só podendo ser dita Outro, que a mulher o oferece sob a espécie do objeto $a$ ?” (p. 257).

Em outras palavras, a fascinação do Outro exige a infinitude do Um e sua tentativa de estabelecer um rapport sozinho; é o não todo - do Outro, do corpo, do objeto, do ser, da verdade - entre o centro e a ausência da unidade, que sustenta a equivalência unitária do significante e permite seu mecanismo de significância: "Se a mulher não fosse 'não toda', se em seu corpo ela não fosse 'não toda' como ser sexuado, nada disso [Um da fusão universal] se sustentaria" (Lacan, 1972-1973/2010, p. 23). A finitude dos espaços abertos que contêm o espaço compacto do gozo fálico implica a enumerabilidade desses conjuntos: uma a uma, ordenação. O Outro exige essa listagem, o Um cria seus resíduos. O mito de Dom Juan é colocado no feminino: é porque "todas as mulheres" é um impossível que sua abordagem se dá no caso a caso.

A lista é aberta; a contagem é das perdas, porquanto o todo é mera projeção descompletada da parcialidade que conta sem saber o que conta. O excesso necessário da abertura encobridora é o resto da abordagem pelo fecho, assim como o "ainda não todo" da aproximação de um irracional afasta o limite desse número que vaza da compacidade da estratégia unitária. A finitude dos abertos significa a subordinação desse tipo de conjunto à compacidade estabelecida, pois a unidade projetada de um ponto na reta constrange a indeterminação desse tipo de número. A contagem pelo Um se bifurca em um traço que faz seu limite e um rastro que lhe escapa. Abertura é inapreensão e irracional é indeterminável: inalcançáveis, inabordáveis com as lentes do todo, pode-se contudo ultrapassá-los, com a 
previsão do fato de finitude dos abertos e o fato de que um ponto é fechado; contam-se abertos sem saber o menor e o maior de seus pontos e estipula-se um ponto sem saber onde ele termina.

A infinitude da lista do Um se articula ao limitado catálogo das pulsões:

Nada pode cobrir esse furo, apenso a todos os órgãos, se não for aquilo que os descobre. Ele os descobre e recobre num mesmo movimento. Ocupa o lugar exato do qual sua questão traçou o contorno. A imagem do corpo se encontra aprisionada no próprio lugar onde ressoa o apelo da totalidade. . . Porque o Outro da linguagem forma um conjunto aberto pelo próprio objeto das demandas que o constituem, tapar essa hiância, formar a partir dela uma totalidade, engendra esse primeiro sonho de gozo onde o sujeito copula com a linguagem. (Pommier, 1991)

O Um projeta um limite que ele mesmo nunca atingirá. Uma "exigência lógica" da linguagem, precisa Lacan (1972-1973/2010, p. 22): posicionado no lado não todo, o lado do irracional, da abertura, do objeto, o ser sexuado encarna o fato de que o significante está radicalmente separado do que o Outro gozo projeta em sua realidade compacta. Isto é, o fantasma de um Outro do Outro que ronda a aproximação enganosa do fechamento da significação. Porque o simbólico é um espaço aberto, esse significante permanece irracionalizável, $\mathrm{S}(\mathbb{A})$, orientando todavia os fracassos do gozo do idiota. $\mathrm{O}$ fecho acredita escrever o ponto não vazio, imagina um Outro onde há a projeção do Um, confunde ex-sistência com predicabilidade. Sua totalização visa se finitizar, mas a abertura em que está comprometido como falante introduz a cada passo o corte de seu ser como sexuado, isto é, ser de gozo. Uma a uma: incomensurações e inominações do fracasso. 


\section{A diferença, o sexual: não Um, não Outro, não Ser}

A contradição é o barramento do sujeito lacaniano, cuja inacessibilidade ao Ser é dupla enquanto tentativa e desmanche. A possibilidade da distinção oca do significante e a impossibilidade do oco ser maciço. O dois só aparece como a dualidade necessária da contradição mesma, noção que o Um instaura, efeito formal; não especularidade pura que se redobra na oposição das figuras unitárias "cheias de querer ser".

Por e contrapor, existir e inexistir, racional e irracional: a quebra do sufixo é a triste notícia da inconsistência simbólica, constatação da negação material que (des)faz o significante. O que a unidade carrega como desunidade própria, desunião, é exatamente a diferença: não "a sexual", mas o sexual.

Só há diferença, o que se exprime pelo Yad'lun como aforismo da ex-sistência. Um não fundamental que se aglutina em torno de sua própria unicidade e nega a não alteridade simbólica no efeito de significado. A extensionalidade dos significantes pela diferenciação recíproca é o fato sozinho da desidêntidade de cada Um, cuja unidade se motiva pelo impossível que a organiza. O que cada elemento discreto não é outro nesse mesmo nível objetivo advém da contradição que a própria unitarização carrega em sua própria emergência. O paradoxo do simbólico é sua impossibilidade de identificar que se realiza apesar disso; o semblante fica à mercê da recusa que o sustenta: ele não é Um como verdade, embora o acredite.

Crença tributária do parceiro do amor, a mais grosseira imagem de suplência à não relação (Lacan, 1972-1973/2010). O Outro é a inconclusão ontológica do Um, duplicidade aparente porquanto a diferença simbólica por atributo inexiste.

A inexistência que se reitera em sua mesmidade, o Um real, que contradiz a positividade enumerável do símbolo mas lhe é objetivamente equivalente, é antes de tudo um paradoxo em si mesmo, pois é vislumbrado como identidade possível a despeito de sua irrealização permanente. Distinto de si mesmo, inexiste como impossibilidade logicamente determinada, mas equivale ao vazio único que o identifica na mesmice, regime solitário do racional. A possibilidade de sucessão, diferenciação material, a sincronicidade significante, advém da instalação da igualdade que todavia depende da diferença simultânea num sistema; fato de que o Um é pura negação, não do Outro mas de si mesmo; o Outro é barrado porque o Um é sozinho 
em sua inconclusão, em sua desunião de base. Sem metalinguagem, a contradição interna desemboca na inconsistência fundante.

O mesmo impossível, entre as negações, a que nega sua autodiferença pela mesmidade da diferença (ilusão de igualdade), negada pela inexistência de sua realização, sua indeterminação constitutiva. O exercício gozoso dessa duplicidade é sua separação apesar de sua ligação pela impossibilidade: necessário porque impossível, impossível porque necessário.

Neste capítulo final ensaiamos respostas à questão que nos motivou: o que faz "homem" e "mulher" para o Lacan dos seminários entre 1971 e 1973 e do texto L'étourdit? Como a irrealização ontológica própria ao sujeito se deslinda como "diferença", sinônimo de "sexual" em psicanálise? Onde se dá a separação entre "homem" e "mulher" na mesma impossibilidade que os enlaça na estrutura, já que esta é “o real que vem à luz na linguagem” (Lacan, 1973/2003, p. 477)?

Interrogando a diferença que indefine o significante, trazemos aqui suas consequências para a sexuação.

\subsection{O Um, o zero: mesmidade da diferença, diferença da mesmidade}

Diferença: do latim, differe; di exprime distância, separação, dispersão, ruptura; ferre significa carregar: diferença é "levar embora" [porter au loin], sintetiza o dicionário Littré (2021). "Secção de predicado", quis Lacan (1972-1973, p. 24). A evanescência própria do que Um significante representa para Outro significante, o exercício dessa secção, é a contradição da contradição. Onde pode a autonomia do símbolo encontrar a alteridade que realizasse a função do ser? A contradição da pergunta a responde. A objetividade exclusiva da ordenação simbólica funciona necessariamente por diferenciação interna, constatação lógica do Um que se destaca a despeito de não ser destacável: ele não tem identidade. A objetivação discreta dos elementos neutraliza a contradição de cada Um sobre si mesmo, o que cada Um leva embora por não ser.

A duplicidade do significante ecoa a duplicidade do zero. Cada significante, suportado pela unidade e a respectiva noção de limite, participa de um todo projetado. Acompanha-lhe 
forçosamente a dedução do que resta fora do que se fechou: presença e falta, aqui e lá, entrada e saída. A contradição unitária é o fato de que o significante exerce seu velamento objetando a disformidade que contradiz a unidade em si mesma: Yad'lun, que "se destaca de algo que não tem forma" [tradução nossa] (Lacan, 1971-1972, p. 51).

Frege fundamentou a lógica interna do simbólico pela ambiguidade: a organização das unidades arrasta a contradição de base do sistema, o desigual a si mesmo que faz do zero ao mesmo tempo a denúncia do impossível e o paradigma do possível. O que não se identifica a si mesmo rompe com “o modo do pensamento", que "só pensa por meio do Um” (Lacan, 19711972/1997, p. 126).

... de onde se pode designar, na linguagem, um objeto sobre o qual seja assegurado que ele não seja
diferente de si mesmo? . . . é em referência a isto que o conceito ao qual convém o número 0 repousa,
sobre isso que se trata do idêntico a 0 , mas não idêntico a 0 . Que aquele que é simplesmente idêntico a 0
é tomado como seu sucessor e, como tal, igualado a 1 . A coisa se funda sobre isto que é o início dito da
equinumericidade; é claro que a equinumericidade do conceito sob o qual não cai nenhum objeto a título
da inexistência é sempre igual a si mesmo. Entre 0 e 0 , nenhuma diferença. É a nenhuma diferença sobre
a qual, por este viés, Frege pretende fundar o 1 . (Lacan, 1971-1972/2003, p. 55)

Conceito impossível; mas justamente por ser a referência do contraditório, a contradição em si mesma, faz de sua invariabilidade a identidade que a linguagem precisa para significar. Só há contradição, mesmice determinada na reiteração, o que implica que a existência seja insistência. Sintetiza Cardoso (2010): "A identidade de contraditórios, mecanismo dialético por excelência, se situa no coração da própria atividade de redução da contraditoriedade”.

O objeto impossível se conta, se delimita; sua diferença a si mesmo se indiferencia por ser a única constatação pertinente da articulação significante. Dessa primeira contradição, a duplicidade do zero, seu não Um que se certifica de ser Um, a duplicidade do significante, entre dito e dizer, sim e não, certo e errado, repete a negação da diferença pura. Um simbolicamente positivo e Um ainda por vir ou ainda por desdizer, Um que supostamente encarna a verdade e Um que supostamente encarna a mentira (falta da verdade): não é outra coisa que o "vagido" do "não é isso" da indeterminabilidade primordial" ${ }^{24}$ (Lacan, 1973/2003, p. 452). A impossibilidade de identidade é o não Um de cada Um que "leva embora" para si mesma o todo e faz da linguagem "essa deriva" (Lacan, 1973/2003). Não Um a mais, falha do reflexo da necessidade lógica enquanto fabricação de Uma falta, que não cessa de faltar: "a unidade e o zero, tão importantes para toda constituição racional do número, são o que há de mais resistente", pois se autodeterminam por sua impossibilidade (Lacan, 1961-1962/2003, p. 170).

\footnotetext{
${ }^{24}$ É o mesmo raciocínio desenvolvido em 2.3 O Zero, a Mulher e o Outro.
} 
A desidentidade unitária que cada significante representa desliza portanto um problema, objetivo, material, que expõe o questionamento da existência, desamparada do Ser. A irresolução do referente sugere a inexistência como função, o mecanismo mesmo do significar, determinável pela própria diferenciação simbólica: assinala-se o não inscritível segundo a inscrição falha do significante, que concebe a contradição que motiva seu devir pelo limite interno que se desenha como falta.

Da necessidade de discurso se produz a inexistência que o símbolo define paradoxalmente como preliminar, a base de seu funcionamento, o que no discurso analítico se sugere como princípio da repetição (Lacan, 1971-1972/1997, 1971-1972/2003). Assim,

. . . a mesmidade não poderia nunca ser cronologicamente primeira. Ela deve ser sempre engendrada retroativamente pelo fato mesmo do sistema de diferenças copresentes, isto é, como uma espécie de subproduto derivado da instalação da ordenação simbólica. Em outras palavras, uma vez instaurada a ordem significante, a inexistência surge como Uma de maneira retroativa. (Cardoso, 2010)

Cada unidade significante carrega a impossibilidade que se transfere de 0 para 1 , a contradição mesma que se afirma nos impasses da lógica. $\mathrm{O}$ brilho e o apagamento que cada peça simbólica pode exibir no imaginário é efeito de que não há metalinguagem; aquilo a que o signo se refere é a sua falta de referência. Não a realidade empírica ou reflexo da subjetividade, mas a contradição lógica como condição da necessidade lógica; seu fundamento é a inexistência de um regime simbólico total, perfeitamente encaixado, espelho do pensamento. A pura diferença é a objetividade contraditória do fato de discurso. A resolução se faz pelo esquecimento e pela decisão de sentido, pelo velamento de que a verdade está enraizada em sua própria negação.

Haveria rapport se não houvesse contradição: lei que o próprio significante permite articular a despeito da contradição que ele veicula em sua matéria. Significado precário como qualquer outro se é da diferença que ele emerge, ao fazer dessa monotonia do impossível pura diferença paradoxalmente indiferente de si mesma — o molde da igualdade temporária que remedia o irremediável. A contradição é o significante, que todavia a contraria no questionamento da existência; cada significante só pode ser diferente de outro porque ele é diferente de si mesmo, embora não pareça: "o significante não somente não está submetido à lei dita da contradição, mas é mesmo aí o suporte, ou seja, que A é utilizável como significante na medida em que A não é A" (Lacan, 1961/1962, p. 133).

Do "não" formal se assegura o "sim" que traz em sua semântica o resíduo do "falso" como mero efeito colateral da pura diferença, resistência do equívoco do "não há", identidade do desidêntico. Cada marcha simbolizante reitera a mesmidade de sua indeterminabilidade, 
miticidade masturbatória de Um a mais que retorna à generalização da diferença fingindo ser igualdade. Não há unidade Outra que não a unitarização do impossível, possibilidade de universalização do sentido.

A fragilidade da determinação simbólica está na inconsistência da existência: sem esse outro apoio objetivo que fizesse relação, a reflexividade do significante desemboca no abismo único de existir sem ser. In-con-sistir: não consistir em mais nada que a negação de si mesmo.

\subsection{A contradição, o gozo: necessário, impossível}

A não relação sexual é o zero. O que quer que se enuncie pelo significante é a reprodução da contradição de sua formação. A sequela é sua assombração no fazer sentido enquanto dependência da diferença, puramente e necessariamente, pois o que o campo da verdade rejeita como indeterminado, sem identidade, paradoxalmente é o que possibilita a formação do verídico. O para-doxo da pulsão é satisfazer-se no Um que não há:

Sob o pretexto de que o corpo é evidentemente uma das formas do Um, que se mantém unido, que é um indivíduo salvo acidente, ele é, é singular, promovido por Freud, e é, para dizer a verdade, o que questiona a díada proposta por ele de Eros e Tânatos. Se ela não estivesse sustentada por outra figura que é precisamente aquela na qual fracassa a relação sexual, isto é, aquela do Um e do não-um, isto é, zero, vêse mal a função que poderia manter este par estupefaciente. (Lacan, 1971-1972/2003, p. 86)

O Um da vigência simbólica se atualiza do não Um que obstaculiza seu fecho. A própria definição do real, que não é "um limite contra o qual batemos a cabeça", mas "o obstáculo lógico, o que do simbólico propriamente se enuncia como impossível" [tradução nossa] (Lacan, 1969-1970, p. 74). A impossibilidade se declina do possível, não como ausência mas como presença de sua causalidade. A ausência do Outro é presença do objeto da pulsão, cuja incomensurabilidade ao Um faz a desproporção sexual, "marca e consequência da incompletude" (Le Gaufey, 2014, p. 136).

A irresolução ontológica do sujeito reitera o valor lógico indeterminado que se transcendentaliza como diferença em si mesma pelas diferenças recíprocas e infinitas da metonímia do desejo. Falta-a-ser, "ser da falta/vazio [lack/void]”, "ontologia do buraco [trou]", “ontologia negativa” (Zupančič, 2008, p. 18; Badiou, 1980, p. 152; Safatle, 2007, p. 150): de todo modo a ex-sistência que acompanha a oscilação simbólica do sujeito é a função do 
impossível sobre a qual se funda tão somente a marcação de um impasse, mesmo que sob a aparência de uma certeza.

Se não há rapport, há no entanto uma continuidade: não Um e não todo são a própria definição da contradição que constitui a matéria simbólica, a autorrescisão coincidente da unitarização. Contradizer é opor-se ao que é dito, negar o que se afirma como unidade formal e semântica. Tudo que é dito é semblante, é verdade e faz gozar, e está implicado no desfazimento da não inscritibilidade que o prolonga e o destotaliza. Compacta-se na retórica do ser a mesmidade da diferença como igualdade imaginária; mas a resposta gozosa que se quer verdade total é ao mesmo tempo apelo ao real, pois a diferença em si mesma não se diferencia: resta enquanto pura contradição de todas as ficções do gozo de palavra.

Assim, a desproporção ou diferença "sexual" constitui rigorosamente um pleonasmo. Que se diga já é a perdição que o gozo introduz na aparelhagem perturbada da realidade. A existência significante funda-se nesse condicional, que está implicado na contradição em si mesma que tanto emperra como faz avançar o desenvolvimento da lógica. A divisão própria à gramática assenta-se na inexistência de metalinguagem, fratura discursiva que é o próprio exercício da diferença, permitindo e negando o sentido. A insistência pulsional como indeterminabilidade do significante é o sexual, falta que contorna a negação de seu próprio traço, pois a reiteração de Um a mais na qualidade de Outro é o dizer da contradição, da diferença.

Genital tão somente em sua parcialidade (im)possível, a sexualidade é uma questão constante; é parcial porquanto não é total. A linguagem "tem a ver com o sexo" (Lacan, 1971/2019, p. 164) não enquanto sentido primordial ou qualificação do vazio que lhe escapa; é a diferença de sua materialidade sobre si mesma que faz sua desproporção existencial, vivida na carne do falante agitado por seus efeitos. O sexual é a diferença, cuja irresolução se manifesta no "isso não vai bem" que os discursos arrastam em seus esforços de verdade (Lacan, 19721973/2010, 98): “é pelo fato de o discurso começar que a hiância se produz. Isso é totalmente irrelevante para o resultado. O certo é que o discurso está implicado na hiância, e que, como não existe metalinguagem, não pode sair dela”.

Os falantes acreditam-se seres conforme as metades identificatórias que o imaginário parece lhes dar, a metade homem e a metade mulher - metades de qualquer pareamento sexual —, resolução edípica que supre o rapport pela questão do ser ou do ter o falo. Mas a intromissão 
do significante na divisão dos órgãos do corpo, escavando o lugar de onde o efeito de ser realiza essa suplência, é assunto do sujeito.

A alçada imaginária não se confunde com a impossibilidade que se demostra cingida pelos ditos. O Eu é metade do sujeito, perdida a cada retomada de encontro, como Lacan já dissera em Variantes do tratamento padrão (1955/1998) e no seminário sobre As psicoses (1955-1956/1988). Entre o meio-dito da verdade limitada pelo gozo do semblante e o meiodizer que não esquece totalmente a ex-sistência do Outro, o radical desencontro, conforme o matema da fantasia, designa a parcialidade da significância pulsional. Entre o Um e o Outro, entre o sentido e a significação, sua gramática organiza os lugares discursivos que escrevem a impossibilidade de escrita do rapport.

Assim, a Outra metade do sujeito, dita mulher, satisfaz a função fálica pelos quantificadores negados, pois o regime existencial do argumento advém de que não há limite à função $(\bar{\exists} x \overline{\Phi x})$, o que significa ausência de universalidade $(\overline{\forall x} . \Phi x)$ : "para se produzir como metade a se dizer das mulheres, o sujeito se determina de que, não existindo suspensão na função fálica, tudo possa dizer-se dela, mesmo que provenha do sem-razão" (Lacan, 1973/2003, p. 466).

Irracionalidade que propriamente constitui o dizer, não confundido com o dizer em que o sujeito ex-siste como unidade à função ao se colocar como exceção a ela $(\exists x . \overline{\Phi x})$, permitindo a retomada dos ditos de seu pare-ser. Lacan (1973/20003) traça uma continuidade na impossibilidade que o sexo significa ao ser falante, na medida em que o real do inter-dito do rapport é embaraço compartilhado da coiteração ${ }^{25}$; mas entre o dito e o dizer essa resposta impossível disjunta os modos como os sexos se posicionam em relação ao "calçador da castração" (p. 465). O feminino é onde a razão se desfaz, e qualquer coisa pode ser dita, sem o limite [nia] que a suspensão da função demarca como esperança de sentido; não Um, $\bar{\exists}$, não há [nya], que desmancha o calçador que tanto ajuda o pé e o senso-absexo: “é por uma ab-senso como-não-um [comme-pas-un], através da qual se negaria o universo, que se furta o nãotodo que ex-siste" (p. 470).

Ex-sistência dupla, Um que não e não Um, por ser a mesma contradição, a mesma negação. Cassin (2017) enriquece nossa compreensão ao observar que não é a falta que faz a diferença, mas seu “tropo", isto é, o modo de tratamento da significação (p. 200). Das limitações

\footnotetext{
${ }^{25}$ Coito-iteração (repetição).
} 
constitutivas da verdade - seu semidizer e a articulação do gozo com o semblante — se distingue a direção das falhas: ele goza como filósofo, ela goza como sofista; ele falha pela falta da parceira, aparelhando a realidade no gozo do pensamento, na retórica universalista do bláblá-blá do ser; ela falha louca e enigmaticamente, sem saber o que diz, fala por falar, sem significar com seu discurso de planta.

A conjugação entre $\exists x$ e $\bar{\exists}$ escreve os lugares do dizer, entre o Um que nega [nia] e o não Um, o Um que não há $[n y a]$. A gramática da pura diferença, o destaque de sua invariância tão evidente quanto o fato de que ela é só errância: "é aí que se revela o sentido do dizer, na medida em que, ao se conjugar o nyania que os sexos sussurram em companhia, ele supre o fato de que, entre eles, nyait rapport" [tradução nossa] (Lacan, 1973, p. 12).

A discordância do heteros, alteridade irrealizável por ser negação, erige a homossexualidade do amor, o emblemar-se pelo semblante, dirigindo-se ao semelhante, equívoco entre o segundo e a diferença, equívoco significante [deux/d'eux]. A inacessibilidade do Dois, o paradoxo constitutivo da pulsão, repercute na polivalência do "homodito" à medida que a heteridade não tem relação com o semblante, isto é, o Outro insiste sua radicalidade a cada Um que tenta se passar pelo Ser, a cada meio-dizer que tenta encerrar a verdade do dito. “Ça cause", diz Lacan (1973/2003), equívoco entre "isso fala" e "isso causa": em torno do falicismo buscamos remediar aquilo que dele se furta. Poeticamente: "flutuamos da ilhota falo ao fato de que nela nos refugiamos do que dela se retira"26 [tradução nossa] (Lacan, 1973, p. $13)$.

Só há o gozo fálico, insuficiente e recalcado, não convém ao rapport. Mais fundamentalmente, é o gozo que está em falta, não significável, dito feminino, que não convém ser dito. Aquele não convém porque este não lhe cabe, lhe nega objetivamente. O que é negado é a negação da negação mesma, indeterminação do escrito. A ambiguidade da inconveniência está em que o "não é isso" do gozo esperado está simultaneamente implicado no "não cessa de não se escrever" do outro gozo, o que propriamente faz com que o gozo esteja em falta.

As barras que cada significante encarna para se diferenciar como unidade dos outros e dar conhecimento fictício à experiência barram a contradição semântica que subjaz a cada decisão de sentido; Outro gozo resta como cogitação mas é efeito imaginário do próprio impossível. A indefinição da identidade reproduz tão somente a irresolução que a disformidade

26 “. . . on flotte de l'îlot phallus à ce qu'on s'y retranche de ce qui s'en retranche” (p. 13). 
de fundo repete no sem-lugar da unidade. Nesta ambiguidade se atesta onde o gozo é necessário por falhar e falha porquanto é necessário: "O necessário, na medida em que ele "não cessa de se escrever', é que, o que se produz é o gozo que não seria preciso/não faltaria. É esse o correlato de que não há relação sexual. E é o substancial da função fálica” (Lacan, 1972-1973/2010, p. 133).

A função e o gozo são fálicos segundo o que o impossível implica de necessidade, e vice-versa. A ausência desse outro gozo faz daquele que temos não necessário, caso houvesse outro...: "não é porque não há — e é disso que depende o 'não seria necessário' — que a lâmina cortante deixa de cair sobre aquele que não é o outro" (p. 134).

Nem Um, nem Dois, jamais Outro, tampouco Múltiplo: a diferença é o "levar embora" sem ter lugar do sexual, contradição em si mesma cuja unicidade não lhe garante como matriz da variação.

\subsection{A negação, a ex-sistência: Um que não, não Um}

A contradição se define como impossibilidade de existir: desunidade, declarada como indeterminação pelo logos. Como Aristóteles poderia apontar o que existe sem percebê-lo em sua inteireza, sem constatar o fato de sua enumerabilidade? Como ele poderia rechear de conceito o molde da identidade corpórea, sua concordância consigo mesma, objeto visto? O Um exige um fora: o que sai do mundo fechado? Anulando todos os princípios parmenidianos do ser, isto é, recusando as condições do pensar racional, a desigualdade pura é o limite do que a ideia pode vislumbrar de suas fronteiras pretendidas. $\mathrm{O}$ desigual corrompe a unidade.

A ideia de negação é ponto de vista da universalidade. Ponto, pois necessita se apoiar na identidade que cria o sentido. Nega-o o que não pode sustentar a unidade identificável. Ora, o que o pensamento arrasta como ilegalidade é o próprio solo onde faz sua lei: ele se contradiz ao abolir a contradição, pois só pode dizer na base da antítese; sintetiza contrapondo a tese.

Pela diferença ele imagina essência, mas não se difere de ser pura distinção; distinguese sendo a diferença mesma, efeito dialético. O não que o Um suporta de sua castração motivao a negá-la em narrativas de alteridade, aposta repetida no absoluto. Única negação dupla, Uma 
oposição: o Um que não, estrutura mesma da extensionalidade, iguala-se ao não Um que transcende a oposição unitária, pois ele só pode contradizer outro Um porquanto ambos são privados de identidade; a igualdade própria que lhes é negada é a igualdade de sua unidade com sua autonegação. A afirmação do Um é o desfazimento do Um.

Há aqui um compartilhamento na falha: o jogo de não ser outro do desdobramento simbólico é fato da fragilidade do Um; a ex-sistência que anima o significante é seu exílio em sua própria casa, sua dit-mansion. O que ele pode produzir como o que "há", jogando a indeterminação na lata de lixo do não ser, condiciona-se do "não há" de sua massa sonora, êxodo constante do referente, mesmo que ela se queira preenchida.

Assim, o Um que diz não à castração só pode negá-la por já estar plantado nela, por ser diferente de todos os outros a partir de que ele é diferente de si mesmo. Ele é o exercício da diferença, vazio do autodiferente cuja mesmidade imprópria serve de repetição à igualdade por diferença; a unidade advém como sugestão por sua irrealização. Seu não advento, o não Um, é sua negação segundo a decisão lógica que paradoxalmente o faz o paradigma do existível: “o não existe afirma-se de um dizer, por um dizer do homem, o impossível" [tradução nossa] (Lacan, 1971-1972, p. 24).

Do todos Um exclama sua negação denunciando seu próprio pertencimento, dizendo-se fora da ordem do semblante todavia no gozo de pare-ser, o que constitui a castração (Lacan, 1971). O paradoxo fundamental que o corrompe é a negação da unidade mesma, o fato de que ele se reitera na diferença porque não pode não a ser. Sua autonegação é a resposta do real como demonstração da inconsistência simbólica, impasse formal e cognitivo que o próprio regime unitário cria tentando inventar o Ser. Arremata Récanati (in Lacan, 1972-1973/2010) que a contradição entre $\exists x . \overline{\Phi x}$ e $\overline{\exists x} . \overline{\Phi x}$ é bem o que define o impossível.

É disso que os sexos vivem - ligados pela separação, separados pela ligação —, conforme o que lhes serve do calçador da castração; sexos enquanto expressões do sexual, nuances da ex-sistência, negação última e intrínseca à articulação significante. $O$ hiato compartilhado não diferencia naturezas; ele é a própria diferença, cria material da palavra todavia usada distintamente, por assim dizer.

Envolver-se pela unicidade de seu não para se afirmar necessita da crença, estar “convencido" de se ser mestre [m'être] (Lacan, 1972-1973/2010, p. 129); por outro lado, “é do 
Real que a mulher toma sua relação à castração", isto é, sem necessidade de ser castrada, pois ela não a nega (Lacan, 1971-1972/2003, p. 43).

$\exists x . \overline{\Phi x}$ sustenta o universal sendo o envelopamento existencial afirmado por negação. É ao mesmo tempo o ponto de abertura e encerramento da significação: um fora necessário que se diferencia dos demais, destacando-se como aposta, mas apenas confirmando o possível da castração a que pertence; diferencia-se por estar enraizado na desidentidade: a exceção faz a regra; regula fechos de sentido pela diferença mas na diferença, o limite do gozo fálico em seu comércio com a unidade; sustenta a universalidade da significação pela castração, orienta $\forall x$.Фx pela reiteração unitária e unária da diferença.

$\exists x . \overline{\Phi x}$ se opõe à exceção pois não objeta a castração; a evacuação fracassada do Um que diz não é fato de que "não há Um que não"; o que se projeta de unidade é a impossibilidade de que ela o seja: o que ela desenha pela diferenciação é o que ela nega em si mesma, na própria repetição; o indeterminado que a verdade exclui como fora de seu campo, a desunidade do sem sentido, é a própria castração que ela arrasta se decidindo determinada.

Sem Um, sem todo: a ex-sistência que se pretende unidade por diferença mostra aqui sua cara de diferença, impossibilidade de fechamento que cada elemento significante suporta em sua desidentidade fundamental. A indeterminação implica um aquém ou além da dialética unitária, "entre centro e ausência": não negação da castração, mas negação da negação da castração, isto é, não se definir, não constituir um dentro e um fora; é o que faz da mulher indecidível, pois ela "não está contida na função fálica, sem entretanto ser sua negação" (Lacan, 1971-1972/2003, p. 83).

Récanati trouxe precisões importantes no seminário Encore de Lacan (19721973/2010). Confirmado pelo último, ele expusera no 10 de abril de 1973 que a mulher se relaciona não com o limite da função pai, mas com o Outro barrado, A; não com o Um, mas com o não Um.

A necessidade da função pai nega $\Phi x$, mas a impossibilidade da "função virgem" seria mais bem definida, na visão de Récanati, como "impotência, se esse termo não tivesse já servido para outros fins" (Récanati, in Lacan, 1972-1973/2010, p. 210). Não há $x$ que não se inscreva em $\Phi$, não há ligação ao Um de $\exists x . \overline{\Phi x}$; a mulher só se destaca da função em suplência ${ }^{27}$, não

${ }^{27}$ Vide o segundo capítulo sobre a compacidade. 
em recusa: impotência enquanto ausência do zero marcado como ausência de unidade, que é referência ao falicismo.

Ausência de ausência, mas “gozo-presença” [jouisseprésence] (Lacan, 1971-1972/2003, p. 83): ausência do Um enquanto regime cognitivo, o que significa estar entre Zero e Um, o dentro e o fora, não ser enumerável. Não é de fato uma simetria em relação ao Um da exceção, embora pareça seu inverso; o não Um é justamente o ilimitável, o não delimitável. A impossibilidade de negar a função origina a contingência (impotência, no sentido dado por Récanati) nela: a indeterminação de $\bar{\exists} . \overline{\Phi x}$ é o zero disforme, não o zero formatado pela falta, o exatamente zero; é o zero antes de seu envolvimento pelo Um, o desigual a si mesmo que contradiz a unidade.

$\overline{\forall x}$ seria portanto um todo suplementar, uma possibilidade de um Um a mais, outra universal, mas desemboca no Um a menos, que é como Lacan (1972-1973/2010) define o Outro. Essa pseudounidade afunda na indeterminação de $\exists x \cdot \overline{\Phi x}$, isto é, não é sustentada por nenhuma existência, nenhuma miragem de integridade conforme o que o círculo da diferença simultânea permite ao significante vislumbrar o lugar do Outro. Na "hiância do indecidível”, “entre o não-todo e o não-uma", a mulher "se distingue por não ser unificante", já dissera Lacan (1971-1972/1997, p. 130) no primeiro de junho de 1972. Complementa agora Récanati (in Lacan, 1972-1973/2010): Enquanto nenhum $x$ vier negar phi de $x$ para A mulher, o Um a mais do qual o "não todo" se sente portador
permanece fantasmático. Nenhuma produção é possível a partir do "não existe $x$ tal que não phi de $x$ "
$(\exists x . \overline{\Phi x})$, mas apenas uma circulação do indeterminado inicial. (p. 211)

Na ordem fálica, o Outro suposto pelo ponto de vista do homem é o Um, cuja antinomia frente a seu todos, constituído no tempo de sua exclusão dele, é uma negação repetida, sempre deslocada, que recai sobre uma conjectura de alteridade, o que Récanati (in Lacan, 19721973/2010) chama de "complexo da existência e da alteridade" (p. 212). Uma existência assim suposta em sua inteireza é a crença masculina do encontro com o Outro, mas as duas negações concernidas ao Um não coincidem: do lado $\forall x$, a necessária existência do Um banido o funda na própria castração de onde sai; mas a negação da existência do Um, do lado $\overline{\forall x}$, a inexistência do Um que prescreve a inuniversalidade na função, sustenta o indecidível da mulher em relação a A.

A relação imaginária do homem com a mulher está portanto governada pela suposição da existência unitária da alteridade: o desligamento da exceção se repete criando a 
imaginarização de um Outro do Outro, de Um em Um, a cada abordagem da parceira; mas a falha entre o todo e o não todo está na ausência de uma existência $(\overline{\exists x} . \overline{\Phi x})$ que permitisse esse rapport, que não tornasse a significar falicamente o outro corpo. Pela impossibilidade da alteridade se inscrever na linguagem, a cisma infinita de alcançar o Outro não pode ser nada mais que a sucessão não especular dos objetos $a$, cuja indefinição todavia se coalesce com $\mathrm{S}(\mathbb{A})$, o significante do Outro barrado.

O Outro é barrado pela contradição que o significante cria em seu exercício de distinção, que paradoxalmente não o distingue. A falta, o Um que reitera uma identidade, é a contradição formal e basal da unidade que insiste em se contradizer. A marcha do simbólico é a sucessão da diferenciação do que não pode ser Um: seu cabimento na enumeração exige a repetição pois se funda em ser distinto com a indistinção de sua distinção fatal, sua autoatrofia. A explicação aqui parece confusa pois descreve um paradoxo. Isto é: se a significação da linguagem, unicamente fálica, unicamente diferença sobre diferença, vive do êxito de seu malogro, constrói com sua fratura, a vulnerabilidade do Um e a inexistência do Outro designam a mesma impossibilidade.

É onde os sexos estão ligados pela irresolução matriz da linguagem, a indiferença da diferença, por onde se diferenciam unidades que não o podem ser e por onde também se indetermina o que não se diferencia de ser pura diferença. A discórdia no nível dos universais é onde a duplicidade do gozar, em sua disjunção, está todavia fundada na impossibilidade do sexual não ser diferença. Pela totalização fantasística: o sim e o não sucessivos da existência instável, os traços formados na dependência de uma ex-sistência foraclusiva, a decisão de sentido que convive com o fantasma do falso e do falho; norma macho, quer Lacan. Pelo não todo: o gozo dito feminino, o expletivo, a não negação da castração, "uma existência inteiramente indeterminada" (Lacan, 1972-1973/2010, p. 221), onde a função, diz Récanati (in Lacan, 1972-1973/2010), "é mais do que preenchida, ela ultrapassa” (p. 209); estrutura lógica sofística de recuo, diz Cassin (2017).

"Duas formas inteiramente diferentes de negação", não semânticas, pois seriam "o naufrágio assegurado", o Um que não e o não Um, a foraclusão e a discordância foram sugeridas por Lacan (1971-1972/2003, p. 19) logo no início de ...ou pior. Sua referência pela gramática de Damourette e Pichon articula a nuance da negação na língua francesa com as negações da ex-sistência. "Ne... pas, ne... rien, ne... jamais" efetivamente negam; “avant qu'il ne, "je crains 
qu'il ne", usos do expletivo, não negam, mas marcam uma distância enunciativa, comenta Le Gaufey (2015).

Concluímos com Récanati e Lacan (1972-1973/2010) que o desligamento discordante, por suplência, do gozo feminino equivale à saturação $(\overline{\exists x} . \overline{\Phi x})$ que excede a própria castrabilidade da função, porquanto só é castrável o que se ordena segundo um horizonte de não castração $(\exists x \cdot \overline{\Phi x})$. O não Um goza no índice de sua indeterminação, cuja suspensão no entanto se dá entre o "existe $x$ " $(\exists x)$ e o "não existe $x "(\exists x$.): "entre uma existência que se encontra por se afirmar e A mulher que, pode-se dizer, não se encontra" (p.220). 


\section{Considerações finais}

Esta pesquisa quis saber o que Jacques Lacan propôs ao que chamou de "homem" e "mulher" segundo o rasgo ontológico que constitui a particularidade de seu sujeito, dividido pela indeterminação que o engaja na objetivação.

O recorte entre os anos de 1971 e 1973 se justificou pelo adensamento epistemológico do que seria nomeado, em 1974, "sexuação": de que se trata? Diferença, oposição, afrontamento, repartição, posicionamentos, rede do negócio sexual, opções de identificação sexuada $^{28}$ : expressões lacanianas para a secção de predicado do ser sexuado, implicado no gozo, o ser falante sem qualquer tropismo positivo ao Ser, posto que a fala é falaz.

Nesta lacuna, o que seriam os dois termos? O que constitui a diferença dos sexos? "Diferença sexual" seria a mesma coisa? Diferença no sexual? De ordem sexual? O sexual se diferencia? Qual o estatuto da diferença? Qual o lugar da dualidade segundo Yad'lun? Dois gozos sem o Dois? Onde está a desproporção e a não relação de Lacan? Como a psicanálise pode sustentar uma oposição se o Dois é inacessível?

Vimos, sobretudo no primeiro capítulo, que a abordagem do assunto exige um debate ontológico com a filosofia, o que implica o necessário posicionamento da psicanálise na história do percurso da questão, que é transdisciplinar, pois se refere à fundamentação em si mesma. Como um saber poderia se insinuar sem um tratamento sobre o que "há", mesmo que para dizer que "não há"? Mesmo que para declarar a negação, a discordância, a irrealização?

Justo ponto onde Lacan (1972-1973/2010) acentua a paradoxalidade da linguagem frente a sua indefinição no efeito de sentido, função mais pregnante mas não a única; pois o que se escreve atesta o próprio impasse que a existência significante carrega: "é no próprio paradoxo de tudo que chega a ser formulado como efeito de escrito da linguagem, é no próprio ponto em que esses paradoxos brotam que o ser se apresenta, e nunca se apresenta senão como 'pare-ser"' (p.115).

\footnotetext{
${ }^{28}$ As seis primeiras descrições estão na densa e crítica lição 5 de $O$ saber do psicanalista; a última foi dita em Les non-dupes errent em 14 de maio de 1974.
} 
A expressão sintetiza que o efeito de significado, a imposição da identidade que a linguagem produz, especialmente na imagem corporal, está sempre defasado da ambiguidade semântica e formal do significante; o fato de que cada Um se afirma como unidade apesar de ser o mero deslizamento da impossibilidade da determinação de sua verdade como tal.

A diferença, intervalo que a linguagem abre no corpo pelo equívoco que veicula, é onde a existência vive sua questão. Onde sou no que digo, pergunta a neurose? $\mathrm{O}$ enigma de ser falante, gozo da articulação significante, é a impossibilidade do saber que a psicanálise assinala como sexual. Não saber sexual, mas o saber enquanto o sexual, a hiância própria ao que a libido circunda no que a contradiz. A hipótese do sujeito $\left(\mathrm{S}_{1}\right)$, suposto a qualquer saber $\left(\mathrm{S}_{2}\right)$ que se articule, confunde-se com o indivíduo falante, ficção sustentada pela ligação do verbo (Lacan, 1972-1973/2010).

A repetição unitária da significantização, o que torna possível que os elementos sejam discretos, distingue-se de que cada Um é distinto de si mesmo: contradição do fazer-se Um sem possuir, como essência, o protocolo identitário que a diferenciação recíproca exige no imaginário de seu velamento; o traço se unifica por não poder se sustentar por si mesmo, dependente da diferença entre unidades que só o são porque é única a lei de que nenhuma delas é Uma. Elas só podem ser iguais na diferença sendo a encarnação da diferença na própria materialidade imprecisa que apresentam.

Yad'lun expressa a própria indecisão da unidade em sua estrutura de mot-valise. A palavra inteira e suas partes revezam-se entre figura e fundo, desfazendo e refazendo o rodeamento da indeterminação que exprimem em sua própria existência ambígua.

A monotonia da diferença, como possibilidade única de formação do significante, supre que não haja rapport, pois é o núcleo paradoxal de qualquer protetização ontológica que se articule, em ensaios infinitos de diferenças da pura diferença. A proporção sexual não pode se formular em letras que lhe correspondam. Na suplência da linguagem em tentar "pare-sê-la", em vez da leitura da aparência essencialista que vai junto com a materialidade significante, seu efeito imaginário (discurso do mestre), Lacan frisa a leitura da gramática (discurso analítico), da causa formal do gozo escrita nas letras que formam o discurso.

O sexual é a abertura da representação irresoluta do sujeito na divisão introduzida pela gramática, cuja possibilidade de significação é discursiva, e não metalinguística. O simbólico só pode exercer os meandros da diferença que instaura, o infinito trabalho do Um 
paradoxalmente sem espelho na unidade: ele não pode ser considerado individualmente, pois é dissolução em sua autodesigualdade; não pode ser enumerado, uniformizado, comparado; não se conforma, não une por equivalência, pois não é espécie. Falta-lhe o Outro, sua realização substancial.

Assim Lacan (1976-1977) terminará seu seminário 24:

$\mathrm{O}$ que esse sujeito — sujeito dividido — tem por efeito se o $\mathrm{S}_{1}$ se encontra em nosso tetraedro, já que o que eu assinalei é que, desse tetraedro, há sempre uma de suas ligações que é rompida; isto é: o $\mathrm{S}_{1}$ não representa o sujeito junto ao $\mathrm{S}_{2}$, ou seja, o Outro. $\mathrm{O} \mathrm{S}_{1}$ e o $\mathrm{S}_{2}$ são muito precisamente o que eu designo pelo A dividido do qual faço um significante, $S(A)$. É exatamente assim que se apresenta o famoso inconsciente. $\mathrm{O}$ inconsciente é, no fim das contas, impossível de apreender. [tradução nossa] (p. 70)

A dualidade real do sexual é portanto a duplicidade que a noção mesma de diferença introduz pelo funcionamento da linguagem. A oposição pura do manejo de sua matéria como condição do inconsciente, grifa Lacan (1973) em L'étourdit. O dois é o equívoco que o significante arrasta na indefinição existencial promovida pelo exercício exclusivo da diferença: “o simbólico só sustenta a ex-sistência” (Lacan, 1972-1973/2010, p. 241).

Como essa oposição na ex-sistência faz o que é da ordem do masculino e do feminino para Lacan? Ensaiaram-se respostas sobretudo no último capítulo. No ponto mesmo em que o significante é a negação do rapport o corpo vivente é interpelado a ressoar o paradoxo do gozo.

A necessidade da negação da castração funda a possibilidade da significação, requisito desesperado da diferença que todavia ratifica a desidentidade de onde vem, pois afirma que a uniformização do todo depende de que a impossibilidade do Um, inexistente por ser diferente de si mesmo, se reúna contudo em seu próprio vazio, frágil protótipo da unidade: o "não é isso" da castração é sempre o mesmo, "tédio" [ennui] que é anagrama do "uniano" [unien], que nega e une (Lacan, 1971-1972).

Ora, o sujeito aí se divide por lhe faltar o complemento que a ligação verbal promete na predicação, a alteridade que resta para concluir sua identidade. A negação da castração irrealizada como exceção é negada pelo indeterminado que a própria diferença produz no que articula, a dedução do impossível a dizer que se mede como real (Lacan, 1973/2003). Em L'étourdit isso é chamado "o sentido do dizer" (p. 466).

Nesse sentido, o sexual revelado como monotonia pelo discurso analítico, as metades do sujeito enquanto "homem" e "mulher" conjugam-se no nó atado pelo impossível que as separa. Por um lado, "a ex-sistência de um sujeito" como exceção é "um modo de acesso sem esperança à relação sexual", pois "nada funciona" "senão pelo equívoco significante, isto é, 
pela astúcia por meio da qual o ab-senso [ab-sens, absence] da relação se tamponaria no ponto de suspensão da função" (p. 459). Por outro lado, a carne reverberará a fatalidade sem-lugar do equívoco na negação da negação da indeterminabilidade significante: "para se introduzir como metade a se dizer das mulheres o sujeito se determina a partir de que, não existindo suspensão na função fálica, tudo possa se dizer, mesmo que provenha do sem-razão” (p. 466).

Irracional, declararam os pitagóricos contrariados por alguma coisa que cancelava o arremate de sua mensuração do mundo. A aproximação discreta, cada vez mais precisa, não se fechava no que se propunha: confirmar a universalidade do que acenava uma existência. Como na famosa diagonal do quadrado de lado unitário, produzia-se um "há", a presença de uma medida, que se chocava com um "não há”, a ausência de sua determinação. Não era possível contar o que deveria caber naquele tamanho facilmente assinalável. Não existiam partes enumeráveis que compartilhassem o todo projetado, da diagonal e do mundo, suposto traduzir a satisfação unificante do pensamento, o prazer estético pela integridade, a simetria, a igualdade, o equilíbrio.

Vimos com a compacidade topológica como a solidão da tentativa de supressão da contradição abre sempre alguma coisa no que pretende fechar-se: indetermina-se o significante ao tentar significar a si mesmo, implicado que está na reflexão de sua própria indistinção; ele não pode não ser diferença; abre-se o irracional como consequência daquilo que julga sua racionalidade como propriedade. "Esquema do gozar", sublinhou Lacan (1972-1973/2010, p. 19) com rapidez.

Comprometidos na separação, implicados no "não há" que todo "há" anula sem desativar, os sexos lacanianos ocupam "hiâncias diversas, nem sempre as mesmas", no nexo paradoxal entre o "não cessa de se escrever" e o "não cessa de não se escrever" (Lacan, 19711972/1997, p. 100). A concórdia-discórdia do fato de haver significante, seu efeito de significado conjugado com o recuo material coincidente com essa produção, mostra-se no que arriscaríamos chamar nuances do sexual ou vertentes da ex-sistência: a impossibilidade de ser Um é a impossibilidade de ser Outro.

Se o binário da presença-falta, análogo àquele do verdadeiro-falso, ecoa a ambiguidade da função da linguagem, promotora de encobrimento e vacilação, a negatividade que constitui o sexual é onde Lacan abandona as metades de seu sujeito na mesma impossibilidade, desaguada nas possibilidades formais e semânticas da contradição. "Homem”, tributário da potência herdada do Pai da horda, acredita, vive da limpeza dos equívocos: gozo do idiota; 
“mulher” encarna em seu corpo o Outro e a verdade: gozo místico. Aquele é pitagórico, precisa do sentimento de que "há" uma escala, estabilidade, determinabilidade; aquela não sabe que "não existe" pois desgarra-se da identidade, a possibilidade do significado, mas sabe de seu aturdimento existencial. Se o sexual é o hiato de não ser, ou de ser extraviado, o obstáculo que a objetividade significante escreve nos corpos, sua presença muda apesar da falácia fálica, o sentido do dizer reparte estratégias de oposição material, articuladas ao imaginário, cuja necessidade ou contingência deslindam modos de expressão da insistência da ex-sistência.

O mesmo é o diferente. Cada significante é o mesmo Um que, por sê-lo, realiza a diferença, que é a mesma para todos, mas é ao mesmo tempo a mesmidade da diferença, a contradição que cada unidade encarna ao se inferir dependente da contradição recíproca, de um não todos. $O$ diferente é o mesmo.

Se houvesse uma relação articulável no plano sexual, se houvesse uma relação articulável no ser falante, deveria ser enunciada - aí está a questão — com todos aqueles de um mesmo sexo a todos aqueles do outro. É evidentemente a ideia que nos sugere, no ponto em que estamos, a referência ao que chamei o modelo animal, aptidão de cada um de um lado de valer para todos os outros do outro. Vocês veem então que o enunciado se promulga segundo a forma semântica significativa da Universal. Ao substituir, no que eu disse, cada um por qualquer que seja, ou por não importa quem - não importa quem de um desses lados — nós estaríamos inteiramente na ordem do que sugere o que se chamaria — reconheçam nesse condicional algo a que faz eco meu Discurso que não seria do semblante — pois bem, substituindo cada um por qualquer que seja, vocês estariam realmente nessa indeterminação do que é escolhido em cada todos para responder a todos os outros. (Lacan, 1971-1972/1997, p. 77)

Exprimindo o assunto em seus pontos fundamentais e escorrendo os resíduos essencialistas que os aforismos lacanianos deixaram, por seu mistério, ao longo dos anos, tentamos um tratamento pelo básico; a problemática lógica, os aportes matemáticos, as críticas filosóficas, as renovações na linguisteria. O que é evidente nas obras em que nos debruçamos; o que se repete, se parafraseia, se reveste em outra carapuça epistêmica, o que marinou nos enunciados e culminou no quadro da sexuação. Não pretendemos todavia produzir um trabalho iniciático ou didático, haja vista sua natureza de investigação acadêmica: buscamos responder nossas perguntas, ler e escrever a partir dos argumentos que elas suscitam.

Ficam-nos evidentemente questões em duas frentes triviais: o debate com a comunidade lacaniana e o posicionamento da psicanálise ante as críticas e as apropriações que os estudos de gênero e os estudos feministas realizam a partir do que apreendem da obra de Freud e Lacan.

A primeira frente foi motivação de nosso projeto inicial, posteriormente abandonada pois consideramos que o próprio estado atual do assunto já está suficientemente empobrecido pela mera oposição de pontos de vista sem maiores aprofundamentos epistemológicos. Partidarismos diversos, preconceitos e inércias metafísicas convivem com fundamentações 
precisas e tentativas de clarificação da especificidade do discurso analítico (Almeida, Pizzimenti, \& Estêvão, 2021). Assim, nesta dissertação ensaiamos uma revisitação da sexuação.

A segunda frente não foi objeto de nosso recorte, mas talvez tenhamos deixado uma contribuição relevante ao debate em nosso esforço em expor os fundamentos da questão. Diversos autores contemporâneos, em sua pluralidade de estilo e visão, dedicaram trabalhos para dialogar nessa fronteira mais marcada com o político e o social (Ambra, Silva Jr., \& Laufer, 2019; Copjec, 2012; Cossi, 2019; Leguil, \& Fajnwaks, 2015; Porchat, 2014).

Para finalizar, alguma reflexão sobre o peso histórico do masculino e do feminino na manipulação teórica de Lacan; o valor de sua presença no que até aqui expusemos como despimento atrás de despimento; isto é, o que motiva sua reverberação na subversão epistemológica inaugurada? Ruído ou harmonia, que propósitos, valias e limites extrair?

O "ser como esvaziamento" demonstrado nas contradições do sujeito, retomamos, exibe o labirinto lógico do sexual: hiato único que se divide entre Um e Outro, não proporção, não razão em sua tentativa de dizer sua unidade (Lacan, 1973/2003, p. 486). Questão primordial da filosofia, o "homem", pretendido representar o "humano", foi classicamente objeto de sua reflexão. E a "mulher"? Lacan (1971-1972/1997) a coloca como representação do indeterminado fundamental do logos: "aqui [em Saint-Anne] eu digo o que penso. É uma posição feminina, porque afinal de contas pensar é algo muito particular"; "não é função nossa pensar, nós, homens. Enfim, uma mulher, isso pensa, pensa mesmo de tempos em tempos logo sou, no que, claro, ela se engana" (p. 133).

Rapidamente aguçamos a questão com uma observação de Badiou (2013), para quem o feminino é passagem, ato, criação, processo; diferentemente de como se costuma pensá-lo, isto é, lugar ou posição. No mundo tradicional, a feminilidade era forçada a participar das coerções patriarcais segundo sua própria inconformidade a Uma figura — a doméstica, a sedutora, a amorosa, a santa. Sua impossibilidade de sustentar um lugar fazia do processo de sua existência "um processo ateu": "a mulher é o processo desse não ser que constitui qualquer ser do Um”, é “o que desfaz o Um”. Não que ela seja dupla, como os antigos já observaram muito bem, mas ela é "o processo do fracasso efetivo do Um" [tradução nossa].

Lacan (1971) de fato opõe a tolice e a crença do homem à liberdade da mulher: "a mulher tem uma grande liberdade no lugar do semblante! Chega a dar peso mesmo a um homem que não tem nenhum. São verdades certas que ao longo dos séculos já se faziam perfeitamente notadas" [tradução nossa] (p. 20). Evidentemente é uma "referência estrutural", embora 
performada nos papéis constituídos pelo patriarcado (Lacan, 1973/2003, p. 486). Mas, pelo que estamos refletindo aqui, o que o psicanalista tem a fazer com essa ligação entre fracassos estruturais travestida de comédia tradicional dos sexos?

Não pretendemos iniciar aqui este debate, que não é simples, mas situemos a ambiguidade estabelecida entre o peso cultural desse vocabulário, que por vezes chega a esmagar uma abordagem mais justa da formalização em jogo (Almeida-Santos, \& Ambra, 2021), e sua utilidade como crítica social empreendida por Lacan, que, verdade seja dita, desprestigia e debocha da força dos emblemas viris do velho mundo e elogia e valoriza a desconstrução que o alheamento dito feminino representa, sobretudo em seu programa clínico.

Singularidade talvez seja uma saída, mas é desejável sair dessa contradição? Mantê-la, por ser representativa do equívoco funcionamento da linguagem, em suas vertentes de malogro em seja qual for o encontro? Ou seria melhor uma purificação semântica da teoria, reservando o dois à neutralidade da contradição formal? Sabemos que nenhuma das alternativas escreverá diferentemente o que é apenas desvios e retornos da diferença. Quanto à práxis implicada, é outra questão, embora dependente da anterior.

Aqui tentamos entender o eixo ex-sistencial de um ser perdido no gozo, isto é, sexuado. 


\section{Referências}

Almeida, L. F., Pizzimenti, E. C., \& Estêvão, I. R. (2021, no prelo). A psicanálise e os psicanalistas: (in)tensões com a crítica. Stylus, 40.

Almeida-Santos, L. F., \& Ambra, P. (2021). Incidências da diferença sexual no final de análise: do dual ao singular. Tempo psicanalítico, 52(2), 28-53.

Ambra, P., Silva Jr, N., \& Laufer, L. (2019). O ser sexual só se autoriza por si mesmo e por alguns outros. Psicologia em Estudo, 24, e41497.

Amster, P. (2015). Notas matemáticas para ler Lacan (R. Torres, trad.). São Paulo, SP: Scriptorium.

Badiou, A. (1980). Théorie du sujet. Paris, França: Éditions du Seuil.

Badiou, A. (2008). Conditions (S. Corcoran, trad.). Nova Iorque, Estados Unidos: Continuum.

Badiou, A. (2013). La féminité. Recuperado de https://savoirs.ens.fr/expose.php?id=1396.

Badiou, A., \& Cassin, B. (2013). Não há relação sexual: duas lições sobre "O aturdito" de Lacan (C. Berliner, trad.). Rio de Janeiro, RJ: Jorge Zahar Editor.

Cardoso, M. J. E. (2010). Lacan e Frege: sobre o conceito de Um. Psicologia USP, 21(1), 127144.

Cassin, B. (2017). Jacques, o sofista: Lacan, logos e a psicanálise (Y. Vilela, trad.). Belo Horizonte, MG: Autêntica.

Cevasco, R. (2013). Ser-para-o-sexo e a partilha dos sexos. A peste, 5(2), 93-112.

Chassaing, J.-L. (2018). Lacan, le sexe, et les auvergnats. Recuperado de https://www.freudlacan.com/getpagedocument/27355. 
Cossi, R. K. (2019). Psicanálise e binariedade de gênero: um debate à luz da sexuação. Ágora: Estudos em Teoria Psicanalítica, 22(3), 309-318.

Darmon, M. (1994). Ensaios sobre a topologia lacaniana (E. A. N. Valle, trad.). Porto Alegre, RS: Artes Médicas.

Darmon, M. (2004). À propos des Essais sur la Topologie lacanienne: Préface à la nouvelle édition. Recuperado de https://tinyurl.com/y4n5gy7g.

Dedekind, J. W. R. (1999). Continuidade e números irracionais. Bol. da Soc. Port. de Matemática, 41, 97 119. (Trabalho original publicado em 1872).

Dolar, M. (2012). One divides into two. E-flux jornal, 33. Recuperado de https://www.eflux.com/journal/33/68295/one-divides-into-two.

Dunker, C. (2019). The forgetfulness of ontology and the metaphysical tendencies of contemporary lacanism. Crisis \& critique, 6, 86-113.

Eidelsztein, A. (2006). La topología em la clínica psicoanalítica. Buenos Aires, Argentina: Letra Viva.

Fajardo, R. A. S. (2017). Introdução à análise real. Recuperado de https://www.ime.usp.br/ fajardo/Analise.pdf.

Fink, B. (1998). O sujeito lacaniano (M. L. S. Câmara, trad.). Rio de Janeiro, RJ: Jorge Zahar Editor.

Frege, G. (1992). Os fundamentos da aritmética. Lisboa, Portugal: Imprensa Nacional - Casa da Moeda. (Trabalho original publicado em 1884).

Freud, S. (2016). Três ensaios sobre a teoria da sexualidade. In S. Freud, Obras Completas, volume 6: três ensaios sobre a teoria da sexualidade, análise fragmentária de uma histeria ("O caso Dora") e outros textos (1901-1905) (P. C. de Souza, trad., Vol. 6, pp. 13-172). São Paulo, SP: Companhia das Letras. (Trabalho original publicado em 1905). 
Freud, S. (2011). O Eu e o Id. In S. Freud, Obras Completas, volume 16: o Eu e o Id, "Autobiografia” e outros textos (1923-1925). (P. C. de Souza, trad., Vol. 16, pp. 13-74). São Paulo, SP: Companhia das Letras. (Trabalho original publicado em 1923).

Freud, S. (1975). Análise terminável e interminável. In S. Freud, Edição standard brasileira das obras psicológicas completas de Sigmund Freud (pp. 247-287). Rio de Janeiro, RJ: Imago. (Trabalho original publicado em 1937).

Goldenberg, R. (2018). Desler Lacan. São Paulo, SP: Instituto Langage.

Hobbs, A. (2017). Zeno's paradoxes: the Stadium and Achilles \& The Tortoise. Recuperado de https://youtu.be/yDXtQNBSeh0.

Lacan, J. (1998). Variantes do tratamento padrão. In J. Lacan, Escritos (V. Ribeiro, trad, pp. 325-364). Rio de Janeiro, RJ: Jorge Zahar. (Trabalho original publicado em 1955).

Lacan, J. (1988). O Seminário, livro 3: as psicoses (A. Menezes, trad., $2^{\mathrm{a}}$ ed.). Rio de Janeiro, RJ: Jorge Zahar Editor. (Trabalho original publicado em 1955-1956).

Lacan, J. (2003). A identificação (I. Côrrea et al., trads.). Recife, PE: Centro de Estudos Freudianos do Recife. (Trabalho original publicado em 1961-1962).

Lacan, J. (2005). O Seminário, livro 10: a angústia (V. Ribeiro, trad.). Rio de Janeiro, RJ: Jorge Zahar Editor. (Trabalho original publicado em 1962-1963).

Lacan, J. (2008). O Seminário, livro 11: os quatro conceitos fundamentais da psicanálise (M. D. Magno, trad., $2^{\text {a }}$ ed.). Rio de Janeiro, RJ: Jorge Zahar Editor. (Trabalho original publicado em 1964).

Lacan, J. (2006). Problemas cruciais para a psicanálise (C. Lemos et al., trads.). Recife, PE: Centro de Estudos Freudianos do Recife. (Trabalho original publicado em 1964-1965).

Lacan, J. (2008). A lógica do fantasma (M. A. Lyra et al., trads.). Recife, PE: Centro de Estudos Freudianos do Recife. (Trabalho original publicado em 1966-1967).

Lacan, J. (1968-1969). D’un Autre à l'autre. Paris, França: Staferla. 
Lacan, J. (1969-1970). L'envers de la psychanalyse. Paris, França: Staferla.

Lacan, J. (2019). De um discurso que não seria semblante (D. Oliveira et al., trads.). Recife, PE: Centro de Estudos Freudianos do Recife. (Trabalho original publicado em 1971).

Lacan, J. (1971). D’un discours qui ne serait pas du semblant. Paris, França: Staferla.

Lacan, J. (1997). O saber do psicanalista (A. I. Corrêa et al., trads.). Recife, PE: Centro de Estudos Freudianos do Recife. (Trabalho original publicado em 1971-1972).

Lacan, J. (2003). ...ou pior (A. T. D. Gonçalves et al., trads.). Salvador, BA: Espaço Moebius. (Trabalho original publicado em 1971-1972).

Lacan, J. (1971-1972). ...Ou pire, Le savoir du psychanalyste. Paris, França: Staferla.

Lacan, J. (2010). Encore (A. T. Ribeiro et al., trads.). Rio de Janeiro, RJ: Escola Letra Freudiana. (Trabalho original publicado em 1972-1973).

Lacan, J. (2003). ...ou pior (relatório do seminário de 1971-72). In J. Lacan, Outros escritos (V. Ribeiro, trad, pp. 544-549). Rio de Janeiro, RJ: Jorge Zahar. (Trabalho original publicado em 1972-1973).

Lacan, J. (2003). O aturdito. In J. Lacan, Outros escritos (V. Ribeiro, trad, pp. 448-497). Rio de Janeiro, RJ: Jorge Zahar. (Trabalho original publicado em 1973).

Lacan, J. (1973). L 'étourdit. Paris, França: Staferla.

Lacan, J. (2016). Os não-tolos vagueiam (L. P. da Fonsêca et al., trads.). Salvador, BA: Espaço Moebius. (Trabalho original publicado em 1973-1974).

Lacan, J. (2002). A terceira (A. J. Ferretto et al., trads.). In APPOA (Org.), Cadernos Lacan (Vol. 2). Porto Alegre, RS: Publicação não comercial da APPOA. (Trabalho original publicado em 1974).

Lacan, J. (1974-1975). R.S.I. Paris, France: Staferla. 
Lacan, J. (1976-1977). L'insu que sait de l'une-bévue s'aile à mourre. Paris, França: Staferla.

Lamb, E. (2017). What does compactness really mean? Blogs.scientificamerican. Recuperado de https://tinyurl.com/y49aommd.

Laqueur, T. (2001). Inventando o sexo: corpo e gênero dos gregos a Freud (V. Whately, trad.). Rio de Janeiro, RJ: Relume Dumará.

Larousse. (2021). Recuperado de https://www.larousse.fr/dictionnaires/francais.

Le Gaufey, G. (2014). Hiatus sexualis: la no-relación sexual según Lacan (S. Mattoni, trad.). Buenos Aires, Argentina: El cuenco de plata.

Le Gaufey, G. (2015). O não-todo de Lacan: consistência lógica, consequências clínicas (P. Rona, trad.). São Paulo, SP: Scriptorium.

Lebesgue, H. (1956). La mesure des grandeurs. Paris, França: Gauthier-Villars. (Trabalho original publicado em 1915).

Leguil, C., \& Fajnwaks, F. (2015). Subversion lacanienne des théories du genre. Paris, França: Editions Michèle

Lima, E. L. (1992). Curso de análise - volume 1. Rio de Janeiro, RJ: Instituto de Matemática Pura e Aplicada (CNPq).

Littré. (2021). Recuperado de https://www.littre.org.

Miller, J.-A. (1967). A sutura: elementos da lógica do significante. In E. P. Coelho (Org.), Estruturalismo: antologia de textos teóricos (pp. 211-224). Lisboa, Portugal: Portugália Editora.

Miller, J.-A. (1996). Matemas I (S. Laia, trad.). Rio de Janeiro, RJ: Jorge Zahar Editor.

Morente, M. G. (1980). Fundamentos de filosofia: lições preliminares (G. C. Coronado, trad.). São Paulo, SP: Mestre Jou. 
Pommier, G. (1991). A exceção feminina: os impasses do gozo. Rio de Janeiro, RJ: Jorge Zahar Editor.

Porchat, P. (2014). Psicanálise e transexualismo - Desconstruíndo gêneros e patologias com Judith Butler. Curitiba, PR: Juruá.

Rona, P. (2010). A topologia na psicanálise de Jacques Lacan: o significante, o conjunto e o número (Tese de doutorado, Instituto de Psicologia, Universidade de São Paulo). Recuperado de www.teses.usp.br.

Rona, P. (2013). Uma nota sobre a inacessibilidade do dois. In C. Soler, A repetição na experiência psicanalítica (pp. 159-166). São Paulo, SP: Escuta.

Safatle, V. (2007). A teoria das pulsões como ontologia negativa. Discurso, 36, 149-189.

Sokal, A., \& Bricmont, J. (2001). Imposturas intelectuais: O abuso da Ciência pelos filósofos pós-modernos (M. Altman). Rio de Janeiro, RJ: Record.

Soler, C. (2005). O que Lacan dizia das mulheres (V. Ribeiro, trad.). Rio de Janeiro, RJ: Jorge Zahar Editor.

Teixeira, M. R. (2017). Gênero, semblante e gozo - aproximações e diferenças. Recuperado de https://tinyurl.com/uquluun.

Thibierge, S. (2007). Pourquoi sommes-nous malades de l'identité ? Psychanalyse et identification. Le bulletin freudien, 49, 13-36.

Zupančič, A. (2008). Why psychoanalysis? Three interventions. København K, Dinamarca: NSU Press.

Zupančič, A. (2012). Sexual difference and ontology. E-flux jornal, 32. Recuperado de https://www.e-flux.com/journal/32/68246/sexual-difference-and-ontology. 